\title{
AVALIAÇÃO DO IMPACTO POTENCIAL DA VERSÃO 2000 DAS NORMAS ISO 9000 NA GESTÃO E CERTIFICAÇÃO DA QUALIDADE: O CASO DAS EMPRESAS CONSTRUTORAS
}

Dissertação apresentada à Escola Politécnica da Universidade de São Paulo para a obtenção do título de Mestre em Engenharia.

São Paulo 


\section{AVALIAÇÃO DO IMPACTO POTENCIAL DA VERSÃO 2000 DAS NORMAS ISO 9000 NA GESTÃO E CERTIFICAÇÃO DA QUALIDADE: O CASO DAS EMPRESAS CONSTRUTORAS}

Dissertação apresentada à Escola Politécnica da Universidade de São Paulo para a obtenção do título de Mestre em Engenharia de

Construção Civil e Urbana

São Paulo 


\title{
AVALIAÇÃO DO IMPACTO POTENCIAL DA VERSÃO 2000 DAS NORMAS ISO 9000 NA GESTÃO E CERTIFICAÇÃO DA QUALIDADE: O CASO DAS EMPRESAS CONSTRUTORAS
}

\author{
Dissertação apresentada à Escola \\ Politécnica da Universidade de São \\ Paulo para a obtenção do título de \\ Mestre em Engenharia de \\ Construção Civil e Urbana \\ Área de Concentração: \\ Engenharia de Construção Civil e \\ Urbana \\ Orientador: \\ Prof. Livre-Docente \\ Sílvio Burrattino Melhado
}

São Paulo 


\section{FICHA CATALOGRÁFICA}

Paula, Alexandre Taveira de

Avaliação do impacto potencial da versão $\mathbf{2 0 0 0}$ das normas ISO 9000 na gestão e certificação da qualidade : o caso das empresas construtoras / A.T. Paula. -- São Paulo, 2004. $144 \mathrm{p}$.

Dissertação (Mestrado) - Escola Politécnica da Universidade de São Paulo. Departamento de Engenharia de Construção Civil.

1.Garantia da qualidade (Certificação) 2.Administração da qualidade 3.Construção civil I.Universidade de São Paulo. Escola Politécnica. Departamento de Engenharia de Construção Civil II.t. 
A minha mãe, Alice Rodrigues Taveira de Paula que, enquanto esteve conosco, sempre me mostrou o valor de nossos atos e a importância de lutarmos pelo que acreditamos.

Ao meu pai, Francisco Assis de Paula Primo, por ter sempre me proporcionado as condições para a busca de meus objetivos.

Aos meus irmãos, Adriana e Neto que sempre acreditaram em minha capacidade.

A minha sobrinha Marina, que com sua inocência e alegria sempre me surpreendeu.

E finalmente, mas não menos importante, à pessoa que mais se doou durante esta longa caminhada, minha esposa, Patricia Ferreira de Paula, sem a qual talvez nem para São Paulo eu teria vindo e que, desde os tempos da faculdade vem me apoiando e me motivando nos momentos mais delicados. 


\section{AGRADECIMENTOS}

Agradeço em primeiro lugar o Prof. Dr. Silvio Burratino Melhado, por sua brilhante orientação e acompanhamento em cada etapa do desenvolvimento desta pesquisa, e também pela compreensão e apoio em todas as fases.

Agradeço também ao Prof. Dr. Flávio Picchi, pela brilhante contribuição que deu a este trabalho na ocasião da qualificação.

Agradeço em especial o Prof. Dr. Ubiraci Espinelli, que foi um dos primeiros professores do PCC que conheci e que me mostrou, por incrível que pareça, o que é ser um professor de verdade. Sendo este Professor um dos responsáveis por despertar em mim o interesse pela pesquisa acadêmica.

Agradeço a todos o professores da pós-graduação do Departamento de Engenharia de Construção Civil, Departamento de Engenharia de Produção e do Departamento de Engenharia de Minas da Escola Politécnica da USP, pela competência e dedicação em seus ensinamentos e pelo respeito que tratam todos os alunos.

Aos meus professores do Departamento de Engenharia Civil da UFSCar que deram o pontapé inicial nesta carreira acadêmica.

Gostaria de agradecer o Eng. Márcio Branco, Eng. Esdras Júnior, Eng. Paulo Aleixo e Eng. Erika Sayuri em nome das empresas SOUEN \& NAHAS, REM, TECNOSUL e CETRO, por terem abertos suas portas e fornecido as informações sem as quais este trabalho não teria sido realizado.

Aos amigos e Mestres Eng. Luis Otávio (Tatá), Eng. Carlus Fabrício (Mú), Eng. Luiz Augusto pela cumplicidade e ajuda durante toda a fase acadêmica.

Aos amigos da pós-graduação, em especial aqueles da Sala Asteróide, que apesar de não conviver diariamente, sempre me auxiliaram nos momentos em que precisei.

Ao Eng. Ronaldo Barbosa dos Santos, que como meu primeiro Supervisor direto mostrou-me a importância de saber ouvir as pessoas, e valor do SER e não do TER. 
Ao CTE - Centro de Tecnologia de Edificações, onde pude me aprofundar nos conceitos e na prática da Gestão da Qualidade. E também pelo privilégio de conviver com tantas pessoas fantásticas como Roberto de Souza, Geraldo Mekbekian, Márcia Menezes, Ana Cecília, Gláucia Nahun, Anderson Benite, Giancarlo de Filipi, Marcos Tamaki, Daniel Kamekishi, Maurício Hino, Josaphat e Luciana, Ana Lúcia, os eternos estagiários Saulo e Catalan, Renata, Fábio, Sueli, Priscila, Márcia e é claro Dona Olinda.

Ao Coordenador de Certificação para a área de Sistemas da UCIEE Eng. Sérgio Fellauer, por compartilhar de sua experiência na fase final do trabalho.

Agradeço muito a Deus que durante toda minha vida esteve e sempre estará ao meu lado, me dando forças para continuar a lutar pelos meus objetivos e me ajudando a superar todas as barreiras que a vida nos apresenta. 


\section{RESUMO}

$\mathrm{O}$ interesse mundial relativo à gestão da qualidade tem sido crescente nas últimas décadas. Esse fato está associado às profundas transformações no cenário econômico, político e social, que ocasionaram uma necessidade de reavaliação e questionamento da postura empresarial adotada. A construção civil, em particular, desde o início dos anos 90 , tem se mostrada comprometida com o movimento pela qualidade. No Brasil, tal fenômeno também se verifica e, diante da revisão das Normas da série ISO 9000 e da publicação de sua nova versão em dezembro de 2000 , identificou-se a necessidade de avaliar o seu potencial impacto na gestão e certificação da qualidade em empresas construtoras.

O trabalho traz a discussão das principais modificações propostas pela nova versão da Norma ISO 9000, analisando com mais detalhe a ISO 9001:2000 - Requisitos, que passa a ser a única norma da série utilizada para fins de certificação.

Analisam-se os tópicos voltados para o enfoque no processo da organização, necessidade de comprovação da melhoria contínua e obrigatoriedade de se ter o Sistema de Gestão da Qualidade com o foco voltado para a satisfação das exigências e expectativas do cliente.

Nos estudos de caso são identificados os desafios que cada uma das empresas tiveram que superar para adaptarem seus Sistemas de Gestão de modo a atender aos novos conceitos da Norma. Conclui-se com a análise dos impactos destas adaptações, tanto no âmbito gerencial da empresa, como também na produção, em seus canteiros de obras. 


\begin{abstract}
The worldwide interest related to the quality management has been increasing in the past few decades. This fact is associated with the deep changes in the economic, political and social scenery that has caused a necessity for reevaluation of the adopted entrepreneurial position. The civil construction, in particular, since the beginning of the 90's, has been engaged to enhance the quality. In Brazil, such phenomenon is also verified. The ISO 9000 standards series revision and the publication of its new version in December 2000, identified the need to evaluate its potential impact on the management and certification of contractor organizations.
\end{abstract}

This paper presents the discussion of the main changes proposed in the new version of ISO 9000 series, mainly analyzing the ISO 9001:2000 - Requirements, which is now the only standard of the series used for certification.

The topics focused on the process of the organization, the need of evidence in the continuous improvement and the obligation of having the quality management system focused on the satisfaction of requirements and customers' expectations are analyzed.

The case studies are identified the challenges that each company have to exceed to adapt their Management System in order to meet the new concept of the ISO 9001 Standard. This analysis ends with the evaluation of the impact of this implementation, both in the office and in the production activities, in their building sites. 


\section{SUMÁRIO}

RESUMO

$i$

ABSTRACT ii

LISTA DE FIGURAS III

LISTA DE TABELAS IV

LISTA DE ABREVIATURAS E SIGLAS V

\section{Introdução}

\section{1}

1.1. Justificativa para desenvolvimento do tema 5

1.2. Objetivo 7

1.3. Metodologia __ 8

1.4. Estruturação do trabalho___ 9

2. Análise das Normas 11

2.1. Elementos do Sistema de Gestão 11

2.2. Histórico da Série ISO 9000 13

2.3. Panorama da qualidade 15

2.4. A Série ISO 9000:1994 17

2.5. A Série ISO 9000:2000 26

2.5.1. A NBR ISO 9000:2000 - Fundamentos e Vocabulário 34

2.5.2. A NBR ISO 9001:2000 - Requisitos 37

3. Mudanças no SGQ com a Versão 2000 da ISO 9000 44

3.1. Estrutura e exigências da Norma versão $2000 \_47$

3.2. As mudanças e suas conseqüências.

3.3. A proposta para a Abordagem Sistêmica ___ 61

3.4. Auditoria da qualidade e a nova ISO 19011:2002_ 62

3.5. O processo de auditoria na nova versão da ISO $9000 \_66$

3.6. A certificação ISO 9001:2000_ 69 
4. Estudos de Caso

4.1. Empresa A

4.2. Empresa B 78

4.3. Empresa $\mathrm{C}$ 87

4.4. Empresa D 97

4.5. Comparação entre as empresas 103

5. Considerações Finais 106

5.1. As Alterações da Norma 107

5.2. A Importância do Treinamento 112

5.3. Agregar Valor com o SGQ 114

5.4. As Mudanças no Cenário 116

5.5. Situação das Empresas Estudadas 119

5.6. Propostas de continuidade 121

Anexo A-Modelo da Pesquisa da $1^{a}$ fase 122

Anexo B - Modelo da Pesquisa da $2^{a}$ fase 127 Anexo C-Ferramenta para monitoramento de um dos processos da produção da empresa $B$ 130

Anexo D - Análise de processo da empresa $C$ 132 Anexo E-Ferramenta para monitoramento de um dos processos da produção da empresa $C$ 136 Referências Bibliográficas 138 


\section{LISTA DE FIGURAS}

Figura 1 - Elementos do SGQ para empresas construtoras (Adaptação: PICCHI, 1993) 12

Figura 2 - Estrutura das Série ISO 9000:1994 (Fonte: MARANHÃO, 1996) 18

Figura 3 - Modelo de um SGQ baseado em processo (Fonte: ABNT, 2000) 27

Figura 4 - Modelo de Sistema de Gestão proposto pela ISO 14001:1996 (Fonte: ABNT, 1996) 28

Figura 5- $1^{\circ}$ Passo: Fluxo básico de processo 28

Figura 6-2 ${ }^{\circ}$ Passo: Processos internos ao fluxo básico 29

Figura $7-3^{\circ}$ Passo: Importância do Cliente na revisão 2000 da ISO $9000 \_29$

Figura 8-4 ${ }^{\circ}$ Passo:Introdução do ciclo da qualidade na Realização do Produto __ 30

Figura 9- $5^{\circ}$ Passo: Melhoria contínua aplicada ao $S G Q \_30$

Figura 10 - Seções da NBR ISO 9001:2000__ 37

Figura 11 - Modelo de interação dos processos internos com o SGQ (Fonte: UCIEE,2003) 44

Figura 12 - Interpretação do conceito de PDCA da Série NBR ISO 9000:2000 (Fonte: UCIEE,2003).

Figura 13 - Visão geral das atividades típicas de auditoria (FONTE: ABNT, 2002) 51

Figura 14 - Conceito de Competência (FONTE: ABNT, 2002) 65

Figura 15 - Organograma funcional da empresa A. (Fonte: empresa A) 66

Figura 16-Macro-fluxo de processo da empresa A. (Fonte: empresa A) 73

Figura 17 - Organograma funcional da empresa B. (Fonte: empresa B) 75

Figura 18 - Macro fluxo de processo da empresa B. (Fonte: empresa B) 78

Figura 19 - Evolução do indicador de retrabalho nas obras. (Fonte: Empresa B) 81

Figura 20 - Evolução do indicador de organização do canteiro (Fonte: Empresa B) 84

Figura 21 - Organograma de funções da empresa C. (Fonte: empresa C) 85

Figura 22 - Macro-fluxo de processo da empresa C. (Fonte: empresa C) 88

Figura 23 - Evolução do índice de retrabalho (Fonte: Empresa C) 91

Figura 24 - Evolução do número de acidentes com afastamento (Fonte: Empresa C) 93

Figura 25 - Monitoramento das inspeções de processos (Fonte: Empresa C). 93

Figura 26 - Índice de entrega de aptos na primeira vistoria. (Fonte: Empresa C) 94

Figura 27 - Evolução do desempenho do almoxarifado (Fonte: Empresa C) 95

Figura 28 - Organograma de funções da empresa D. (Fonte: empresa D) 96

Figura 29 - Macro-fluxo de processo da empresa D (Fonte: empresa D) 97

Figura 30 - A Transição para um SGQ Dinâmico (Adaptação: Hoyle e Thompson, 2001) 100 110 


\section{LISTA DE TABELAS}

Tabela 1: Requisitos da ISO 9000 aplicáveis em cada uma das normas da Série (Fonte: ABNT, 1994)

Tabela 2: Correspondência entre os elementos do SQ (Fonte: CTE, 1995) 25

Tabela 3: Descrição dos requisitos da NBR ISO 9001:2000 48

Tabela 4: Sintese das principais alterações na versão 2000 da NBR ISO 9001. 60

Tabela 5: Ações tomadas visando aumento da competitividade 74

Tabela 6: Objetivos, indicadores e metas para os processos de produção (Fonte: Empresa A). 77

Tabela 7: Objetivos, indicadores e metas ligadas ao processo produção (Fonte: Empresa B) 83

Tabela 8: Formas de contratação da empresa $C$ 87

Tabela 9: Objetivos, indicadores e metas para os processos de produção (Fonte: Empresa C). 92

Tabela 10: Estratégias utilizadas pela empresa D para manter a competitividade 98

Tabela 11: Objetivos, indicadores e metas ligadas ao processo produção (Fonte: Empresa D) _ 102

Tabela 12: Quadro comparativo dos estudos de caso 103

Tabela 13: Relação entre "Garantia da Qualidade" e "Gestão da Qualidade" (Fonte: NBS, 2000) 


\section{LISTA DE ABREVIATURAS E SIGLAS}

\begin{tabular}{|c|c|c|}
\hline ABNT & - & Associação Brasileira de Normas Técnicas \\
\hline $\mathrm{ACD}$ & - & Análise Crítica pela Direção \\
\hline AQAP & - & Allied Quality Assurance Publication \\
\hline $\mathrm{BS}$ & - & British Standard \\
\hline CB & - & Comitê Brasileiro \\
\hline CDHU & - & Companhia de Desenvolvimento Habitacional e Urbano \\
\hline CEE & - & Comunidade Econômica Européia \\
\hline $\mathrm{CEF}$ & - & Caixa Econômica Federal \\
\hline CTE & - & Centro de Tecnologia de Edificações \\
\hline DEF.STAN. & - & Defense Standard \\
\hline DICOR & - & Divisão de Credenciamento de Organismos \\
\hline DNV & - & Det Norske Veritas Certificadora \\
\hline FCAV & - & Fundação Carlos Alberto Vanzolini \\
\hline IAF & - & International Accreditation Fórum \\
\hline INMETRO & - & $\begin{array}{l}\text { Instituto Nacional de Metrologia, Normalização e Qualidade } \\
\text { Industrial. }\end{array}$ \\
\hline ISO & - & International Organization of Standardization \\
\hline LLOYDs & - & Lloyds Register Quality Assurance \\
\hline NBS & - & NBS Consulting Group \\
\hline NIT & - & Norma Interna Tecnológica (INMETRO) \\
\hline OCC & - & Organismo de Certificação Credenciado \\
\hline OCS & - & $\begin{array}{l}\text { Organismos de Certificação de Sistema da Qualidade } \\
\text { Credenciados }\end{array}$ \\
\hline OTAN & - & Organização do Tratado do Atlântico Norte. \\
\hline Pará-Obras & - & $\begin{array}{l}\text { Programa Evolutivo de Qualificação de Empresas de Serviços } \\
\text { e Obras do Estado do Pará }\end{array}$ \\
\hline PBQP & - & Programa Brasileiro da Qualidade e Produtividade \\
\hline PBQP-H & - & Programa Brasileiro da Qualidade e Produtividade no Habitat \\
\hline PDCA & - & Plan-Do-Check-Act \\
\hline QUALIHAB & - & $\begin{array}{l}\text { Programa da Qualidade da Construção Habitacional do Estado } \\
\text { de São Paulo }\end{array}$ \\
\hline QUALIOP & - & $\begin{array}{l}\text { Programa de Qualidade das Obras Públicas do Governo do } \\
\text { Estado da Bahia }\end{array}$ \\
\hline QUALIPAV & - & $\begin{array}{l}\text { Programa Municipal da Qualidade em Obras de Pavimentação, } \\
\text { Obras de Arte e Obras de Drenagem Urbana. (RJ) }\end{array}$ \\
\hline RA & - & Representante da Administração \\
\hline $\mathrm{RD}$ & - & Representante da Direção \\
\hline $\mathrm{SAC}$ & - & Serviço de Atendimento ao Cliente \\
\hline SEDU & - & Secretaria Especial de Desenvolvimento Urbano \\
\hline SG & - & Sistema de Gestão \\
\hline SGQ & - & Sistema de Gestão da Qualidade \\
\hline Sinduscon & - & Sindicado da Indústria da Construção \\
\hline SiQ-C & - & $\begin{array}{l}\text { Sistema de Qualificação de Empresas de Serviços e Obras - } \\
\text { Construtoras }\end{array}$ \\
\hline TC & - & Technical Committee \\
\hline UCIEE & - & União Certificadora \\
\hline
\end{tabular}




\section{INTRODUÇão}

Quando analisado o processo de maturação dos conceitos de qualidade no Brasil, verifica-se que, nos anos 90, houve uma migração do anterior status eminentemente operacional e fabril, focada basicamente na qualidade do produto final, para a busca pela qualidade total, privilegiando a gestão dos processos.

Teixeira $(2000)^{1}$ relata que, na década de 80 , a preocupação com a qualidade acontecia como um movimento disperso, fechado em algumas poucas empresas, em setores específicos da economia, e com foco restrito à qualidade nos processos de produção e nos produtos finais. Esta preocupação transformou-se numa verdadeira revolução gerencial em muitas empresas brasileiras na década de 90 , com o foco sendo ampliado para a qualidade da gestão lato sensu. Esse movimento tornou-se um dos impulsionadores de relevo ao desenvolvimento econômico nacional no período.

Assim, nos anos 90 a qualidade ganhou o status de modelo de gestão empresarial, indo além das linhas de produção para os processos gerenciais mais amplos. A família de normas ISO 9000, editada em 1987, consolidou-se na década de 90 como referência de sistemas da qualidade, aceita internacionalmente.

No Brasil, o número de certificados ISO 9000 cresceu exponencialmente, saindo de 18 certificados emitidos em 1990 para $7513^{2}$ em 2003, dos quais 445 referiam-se ao setor da construção civil.

Em 14/12/2003 os certificados ISO 9000 com base na versão de 94 perderam sua validade. A partir daí e se tratando somente dos certificados ISO 9001 na versão 2000 tem-se $3352^{3}$ emitidos, sendo 307 emitidos para empresas com atuações ligadas à Construção Civil conforme descrição IAF (International Accreditation Forum).

\footnotetext{
${ }^{1} \mathrm{O}$ sistema de referência bibliográfica adotada apresenta o nome do autor seguido da data de publicação. Os dados completos de cada referência podem ser encontrados ao final deste trabalho.

${ }^{2}$ Dados obtidos do site: http://www.abntcb25.com.br acessado em 07/04/2003.

${ }^{3}$ Dados obtidos do site: http://www.abntcb25.com.br acessado em 08/01/2004.
} 
Embora a ISO 9000 deva ser considerada como um dos mais importantes indutores da qualidade na gestão empresarial brasileira, refletindo sua enorme aceitação mundial como elemento facilitador do comércio internacional, seu escopo muito focado na padronização de processos produtivos não foi o fator determinante da mencionada mudança de status experimentada pela qualidade. Prova disso é que sua recente revisão ISO 9001:2000 amplia significativamente seu escopo, que passa agora a incluir questões sobre a gestão do "negócio", isto é, passa a considerar o desempenho da organização.

Não se pode deixar de considerar que fatores conjunturais importantes foram os mais fortes elementos de impulso da citada revolução pela qualidade total. O novo ambiente competitivo estabelecido com a globalização e a abertura econômica do país, expondo as empresas brasileiras ao duro jogo da competição internacional, ressaltou o valor da qualidade da gestão, segundo os postulados básicos da qualidade total, tais como o posicionamento estratégico com foco no cliente e no mercado, a gestão das informações competitivas e a liderança para a excelência.

Segundo Teixeira (2000), foi a necessidade de competir em termos globais, aumentando vigorosamente sua participação em mercados do exterior, que acelerou dramaticamente a conquista de certificados ISO 9000 pelas empresas brasileiras. Também a drástica mudança no ambiente macroeconômico, com a queda vertiginosa da inflação, revelou mais claramente as ineficiências e deficiências da gestão de muitas empresas.

No novo contexto instalado, os ganhos de aumento de produtividade e da efetividade do sistema produtivo, possíveis com a gestão pela qualidade total, antes considerados marginais no ambiente inflacionário brasileiro, tornaram-se importantes fatores de aumento de margens nas vendas, aumento da rentabilidade dos produtos e aumento da lucratividade das empresas de modo geral.

Mais para o final da década de 90, o modelo da gestão pela qualidade total reforçou seu foco em resultados empresariais, vistos de modo balanceado segundo diversas dimensões, com destaque para os resultados de clientes e mercado e de desempenho financeiro. Essa nova e importante ênfase tornou a abordagem pela qualidade mais 
pragmática e menos "romântica", contribuindo para o aumento do interesse neste modelo pelas empresas.

Certamente, o Programa Brasileiro da Qualidade e Produtividade (PBQP), lançado pelo governo federal no início da década de 90, constituiu-se em elemento de integração de esforços, de disseminação de informações e experiências, e de estímulo à aplicação crescente de novas práticas gerenciais, para a consolidação da gestão pela qualidade total no país.

Naquele início de década, sob o patrocínio do PBQP, intensificou-se o intercâmbio com instituições americanas, européias e japonesas, de modo que rapidamente formou-se uma expressiva competência nacional quanto à gestão pela qualidade total, multiplicada para muitas empresas.

Segundo Fontenelle (2002) o setor da Construção Civil no Brasil ainda aparece freqüentemente rotulado como um setor "atrasado" quando comparado a outros setores industriais devido à sua baixa produtividade global, em função, principalmente, de seu baixo nível de industrialização, elevado desperdício de materiais e reduzida qualificação de sua mão-de-obra, o que resulta também na baixa qualidade de seu produto final.

Grande desigualdade nos padrões de qualidade, prática da não-conformidade intencional, desarticulação, concorrência predatória, esperdício na produção e obras e baixo nível de inovação tecnológica. Isso tudo se refletia em um habitat urbano de baixa qualidade, necessitando de constantes reparos e serviços de manutenção, além do desperdício de matéria prima, que significa poluição ambiental e moradias mais caras.

Este era o retrato do setor da construção civil, um dos setores produtivos mais importantes da economia, mas que necessitava de um esforço conjunto em busca da qualidade e produtividade.

Em 1998, esse esforço ganhou corpo com a criação do Programa Brasileiro da Qualidade e Produtividade no Habitat (PBQP-H), com enfoque inicial no setor da construção habitacional; posteriormente, o programa teve seu âmbito ampliado para a 
inclusão do conceito de "Habitat", envolvendo não apenas a habitação, mas também as obras civis nas áreas de saneamento e infra-estrutura urbana, possibilitando assim uma abordagem mais sistêmica e integrada da gestão do ambiente urbano.

Foram emitidos, até final de 2003, $1313^{4}$ atestados de qualificação nos diversos níveis evolutivos ${ }^{5}$ do PBP-H em todo o país.

Por meio do PBQP-H o Governo passou então a apoiar o esforço de reestruturação do setor produtivo em torno de duas questões fundamentais: a melhoria da qualidade do habitat e a modernização produtiva. O setor público participa essencialmente como indutor de um processo evolutivo de qualidade, e o setor privado assumindo o compromisso com a implementação dos sistemas de qualidade do programa.

Observa-se que houve grandes mudanças no setor da Construção Civil brasileira. De acordo com Rocha (1998), cada vez mais, as empresas construtoras investem na melhoria da qualidade através do uso de tecnologias inovadoras ou da implantação de sistemas de gestão da qualidade para atender às novas necessidades de mercado.

Fontenelle (2002) acrescenta que houve uma maior conscientização dos consumidores, notadamente após a aprovação do Código de Defesa do Consumidor (Lei 8078/90) que deram respaldo legal e agilidade aos processos de denúncia de falhas ou vícios de construção em edificações, e também pela queda de seu poder de compra devido à inúmeras crises financeiras sofridas pelo país neste período.

Este cenário levou as empresas construtoras a mudarem suas estratégias competitivas para que pudessem sobreviver neste mercado, estas mudanças passaram a considerar necessariamente, os aspectos de melhoria da qualidade de seus produtos e de maior eficiência nos seus processos de produção.

\footnotetext{
${ }^{4}$ Dados obtidos da lista de empresas qualificadas atualizado em 19/12/2003, disponível no site http://www.cidades.gov.br/pbqp-h .

${ }^{5} \mathrm{O}$ programa do PBQP-H possui 4 níveis de qualificação evolutiva, sendo D, C, B e A. Em cada um deles as exigências em relação ao atendimento aos requisitos da norma vão se tornando mais completas.
} 
De acordo com Souza (1997), o movimento pela certificação ISO 9000 vem ganhando corpo no setor da Construção Civil desde a década de 80, liderado por empresas construtoras tanto da área imobiliária quanto da área industrial e de obras públicas.

Picchi (1993) coloca que, para a Construção Civil esse movimento foi, sem dúvida, reflexo da ênfase pela qualidade que vinha ocorrendo em todos os setores e em todo mundo, mas decorre também de mudanças que afetam especificamente esse setor e que têm levado as empresas de construção de edifícios a buscarem métodos de gestão mais modernos, seguindo o exemplo da indústria de produtos seriados.

\subsection{Justificativa para desenvolvimento do tema}

Nos últimos anos, pode-se afirmar que foi presenciada uma verdadeira evolução na área da qualidade, em particular com sistemas de gestão da qualidade ISO 9000.

Entretanto, segundo Battistuzzo (2000), nem tudo é motivo de comemoração. No mínimo, pode-se dizer que há dúvidas sobre qual o grau de melhoria que a implementação da ISO 9000 produziu nas organizações. Em outras palavras, até que ponto as organizações evoluíram devido ao processo de certificação, não somente em aspectos relacionados à qualidade, mas na realização de negócios e ação de seus clientes.

A preocupação com a qualidade, no segmento de edificações, tem sido crescente nos últimos quatro ou cinco anos, pode-se identificar uma série de iniciativas que demonstram o maior interesse da comunidade acadêmica e técnica a esse respeito.

Isso fica evidenciado pelo aumento do número de estudos e trabalhos realizados, ou em fase de desenvolvimento, entre empresas de construção e universidades ou institutos de pesquisa, pelo grande número de eventos relacionados ao tema, pela maior facilidade de se encontrar publicações relativas ao assunto em revistas especializadas e artigos técnicos e, finalmente, pelo crescente número de empresas que, em conjunto ou não, com entidades setoriais, se interessam em implementar programas voltados à melhoria da qualidade e produtividade em suas organizações. 
A certificação com base nas Normas ISO 9000:1994, alcançada por várias empresas construtoras, tornou-se uma espécie de "cartilha" na busca da qualidade. A partir do momento em que essas empresas, em atitude praticamente isolada, começaram a modificar sua forma de atuação no mercado, passaram a influenciar toda a cadeia produtiva, desde projetistas e fornecedores até subempreiteiros que, hoje, já sentem a necessidade de mudar suas atitudes em um mercado cada vez mais exigente em que, a cada dia que passa, os compradores conhecem melhor seus interesses e direitos.

Para que o setor, mais uma vez, não fique atrás na evolução dos conceitos de qualidade, se faz necessário um estudo das alterações da nova versão da Norma ISO 9000, enfocando os impactos causados nas empresas do setor da construção civil.

De acordo com Mendonça (2000), diversas empresas apontaram a adaptação das Normas ISO 9000:1994 à construção civil como um difícil obstáculo a ser superado, sempre havendo a necessidade de forte intervenção de consultores para a sua melhor compreensão.

O fato dos sistemas certificados com base nas Normas NBR ISO 9000:1994 possuírem sua validade expirada em 14/12/2003 tornou-se necessário a análise dos impactos da implantação de um Sistema de Gestão da Qualidade (SGQ) agora seguindo as orientações da NBR ISO 9001:2000, de modo a entender o que modificou nesta versão em relação à anterior.

Neste contexto, a justificativa do tema é de enorme relevância, existem inúmeras questões que precisam ser levantadas e respondidas a esse respeito, de modo a auxiliar o processo de evolução dos sistemas de gestão (SG) em empresas construtoras.

Outro fator motivador à pesquisa é o movimento nacional pela qualidade na construção civil, podendo ser citados além do PBQP-H em âmbito Nacional; QUALIHAB em São Paulo; QUALIPAV no Rio de Janeiro; QUALIOP na Bahia; PARÁ-OBRAS no Pará; entre outros. 
Todos estes programas têm como referência as Normas NBR ISO 9000 e uns já adequados à versão 2000 outros ainda na versão 1994, o que não persistirá por muito tempo.

Pode-se citar ainda mais um fato de relevância para a pesquisa, o de bancos privados como BRADESCO, ABN AMRO REAL e ITAÚ aderirem em 06/12/2002 ao programa, seguindo a estratégia adotada pela Caixa Econômica Federal (CEF), utilizando seu poder de compra de somente liberar financiamento às empresas qualificadas no PBQP-H.

Diante do exposto, fica claro a grande preocupação do setor da Construção Civil na busca pela qualidade e a importância dos SGQ's, considerados um instrumento de fundamental importância para qualquer empresa que pretenda promover sua melhoria contínua, tornando-se, assim, uma empresa preparada para o mercado cada vez mais competitivo.

\subsection{Objetivo}

O objetivo da pesquisa é a avaliação das modificações introduzidas pela adequação dos Sistemas de Gestão da Qualidade de quatro empresas construtoras de edifícios que atuam em São Paulo para torná-los aderente ao enfoque da NBR ISO 9001:2000. Para isto pretende-se coletar informações relativas aos desafios encontrados para esta adequação e as melhorias alcançadas com esta nova configuração de seus SGQ's.

A investigação será concentrada em empresas que tenham seus sistemas de gestão já certificados segundo a versão 1994 e possuem a intenção de atualiza-los com base na versão 2000 da NBR ISO 9001. Ele também analisa as relações organizacionais e de gestão que se desenvolvem entre os agentes envolvidos na implementação e manutenção do SGQ, ligadas às atividades de produção nos canteiros de obra e no próprio escritório central das empresas estudadas. 


\subsection{Metodologia}

A pesquisa utilizou-se, como metodologia para o seu desenvolvimento, de revisões bibliográficas, estudos de caso voltados aos agentes envolvidos e entrevistas com profissionais e especialistas no assunto.

As revisões bibliográficas, fundamentais para um direcionamento adequado do trabalho de pesquisa, no início e também durante todo o desenvolvimento da pesquisa, foram realizadas com o intuito de:

Conhecer as novas diretrizes da série NBR ISO 9000:2000 - Sistema de Gestão da Qualidade;

Tomar conhecimento e apresentar as recomendações da nova NBR ISO 19011:2002 - Diretrizes para Auditorias de Sistema de Gestão da Qualidade e/ou Ambiental;

$\checkmark$ Analisar as opiniões e experiências dos diversos autores e pesquisadores referenciados;

$\checkmark$ Ampliar o conhecimento do pesquisador sobre o assunto.

Nesta fase de aprofundamento dos conhecimentos do pesquisador foram feitas consulta, através de visitas, reuniões e acompanhamento de auditorias, a empresas certificadoras e de consultoria como FCAV, UCIEE, DNV, CTE e NBS, além de reuniões com especialistas da área no ambiente da Universidade, visando:

$\checkmark$ Verificar principais alterações sobre a versão da Norma ISO 9000:2000 observadas na prática por estes profissionais;

$\checkmark$ Confrontar os conhecimentos do pesquisador com aqueles obtidos junto a estes profissionais;

$\checkmark$ Obter sugestões úteis ao desenvolvimento da pesquisa. 
Para a realização do estudo de caso foram realizadas as seguintes atividades:

$\checkmark$ Análise detalhada e circunstanciada das alterações introduzidas na série ISO 9000 pela versão 2000 das Normas, isto se fez necessário para que, uma vez nas empresas, o pesquisador tivesse condições de obter as informações que realmente fossem relevantes ao trabalho;

Elaboração de questionários que tiveram como função orientar o pesquisador durante as entrevistas "in loco". Foram utilizados dois tipos de questionário, o primeiro (Anexo A), aplicado durante a primeira fase do estudo, serviu para dar uma visão geral da empresa e de seu SGQ ao pesquisador; já o segundo (Anexo B) foi aplicado nos canteiros de obras das empresas pesquisadas, verificando os impactos observados pelos envolvidos na produção;

Com os questionários (Anexos A e B) foi feito o levantamento de dados, em quatro empresas construtoras certificadas na versão de 1994 e em processo de adaptação de seu sistema ou que já adaptaram seu sistema em relação à ISO 9001:2000.

\subsection{Estruturação do trabalho}

A dissertação está dividida em seis capítulos. Além deste primeiro que traz a justificativa, objetivos, metodologia e estruturação do mesmo, temos mais cinco capítulos.

O segundo capítulo intitulado de Análise das Normas traz de forma geral os elementos para o entendimento de um SGQ. É mostrado também neste capítulo um breve histórico da Série ISO 9000, um panorama da qualidade no Brasil e no Mundo além de uma análise das séries NBR ISO 9000 de 1994 e de 2000.

No Capítulo 3, são mostradas as principais mudanças necessárias aos SGQ com a publicação da versão 2000 da ISO 9000. São apresentadas as estruturas e exigências desta versão e a proposta de abordagem por processos. É apresentada uma breve análise da NBR ISO 19011:2002, norma utilizada para auditoria de sistema de 
gestão, que já está adequada ao novo enfoque da ISO 9000, além das mudanças nos processos de auditorias e de certificação com este novo enfoque.

Os estudos de casos são tratados no Capítulo 4, levantando as dificuldades e possíveis frustrações com relação aos Sistemas de Gestão da Qualidade (SGQ) implantados com base na versão de 1994 da série ISO 9000, verificando como foi o processo de adaptação dos SGQ para a nova versão da Norma e buscando identificar as dificuldades neste processo e as expectativas das empresas com esta nova realidade.

No quinto capítulo, são apresentadas as considerações finais, em que se faz a análise dos estudos de casos comparando as informações de cada uma das empresas, procurando demonstrar a importância do trabalho realizado.

Nesta parte do trabalho estão relacionados alguns documentos de apoio utilizado durante a pesquisa, estes documentos estão nos Anexos A, B, C, D e E.

O Anexo A traz o modelo da pesquisa utilizada como ferramenta durante as entrevistas iniciais junto às empresas; já o Anexo $\mathrm{B}$ traz o modelo da pesquisa utilizada na fase de investigação em campo.

Os Anexos C e E trazem modelos de formulário utilizado como ferramentas por duas das empresas pesquisadas para monitorar seus processos ligados à produção.

E o Anexo D traz a apresentação detalhada de um dos processos de uma das empresas, estes fluxos foram analisados e auxiliaram no desenvolvimento da pesquisa.

No último capítulo estão relacionadas as referências bibliográficas utilizadas como fonte de consulta e citadas neste trabalho. 


\section{ANÁlise das Normas}

\subsection{Elementos do Sistema de Gestão}

Os sistemas da qualidade definidos na série de Normas NBR ISO 9000 têm aplicação universal. Exatamente por essa razão estas Normas são genéricas e necessitam de adaptações e maior detalhamento em função do setor industrial em questão.

Segundo Maciel; Melhado (1995), a implantação e o desenvolvimento dos programas de gestão da qualidade na indústria da Construção Civil não seguiu o mesmo processo evolutivo da qualidade ocorrido na indústria de um modo geral. Este fato ocorreu devido a diversos motivos e, dentre eles, a idéia da não aplicabilidade dos conceitos de qualidade a este tipo de indústria, por esta apresentar características absolutamente peculiares.

De acordo com Reis (1998), a série de normas ISO 9000 - Normas de Gestão e Garantia da Qualidade - foi elaborada visando atender à indústria seriada. Quando se procura transferir os conceitos e modelos dessas normas para as empresas construtoras, necessita-se um esforço de adaptação considerável, de forma que elas possam também ser utilizadas por uma indústria tão peculiar como é a Construção Civil.

Souza (1997) diz que na Construção Civil, que tem tantas especificidades se comparada à indústria de produtos seriados, o fundamental de um sistema da qualidade não é seguir rigidamente os requisitos das Normas ISO, e sim, demonstrar o atendimento a eles, desenvolvendo sistemas da qualidade adequados ao setor de construção civil e o mais eficazes quanto possível.

Nesse sentido, os sistemas da qualidade para a construção civil devem ser ligados ao ciclo da qualidade do setor, que não é idêntico para todas as empresas construtoras, mas, pode-se afirmar, é muito semelhante.

Assim sendo, um sistema da qualidade que acompanha o ciclo da qualidade da construção deve referendar os seguintes elementos: 
$\checkmark$ Política e organização do sistema da qualidade;

$\checkmark$ Qualidade em recursos humanos e administração;

$\checkmark$ Qualidade no processo comercial;

$\checkmark$ Qualidade no projeto;

$\checkmark$ Qualidade na aquisição;

$\checkmark$ Qualidade no gerenciamento e execução de obras;

$\checkmark$ Qualidade na operação e assistência técnica pós-uso.

A Figura 1 apresenta esses elementos e suas inter-relações, formando o sistema da qualidade.

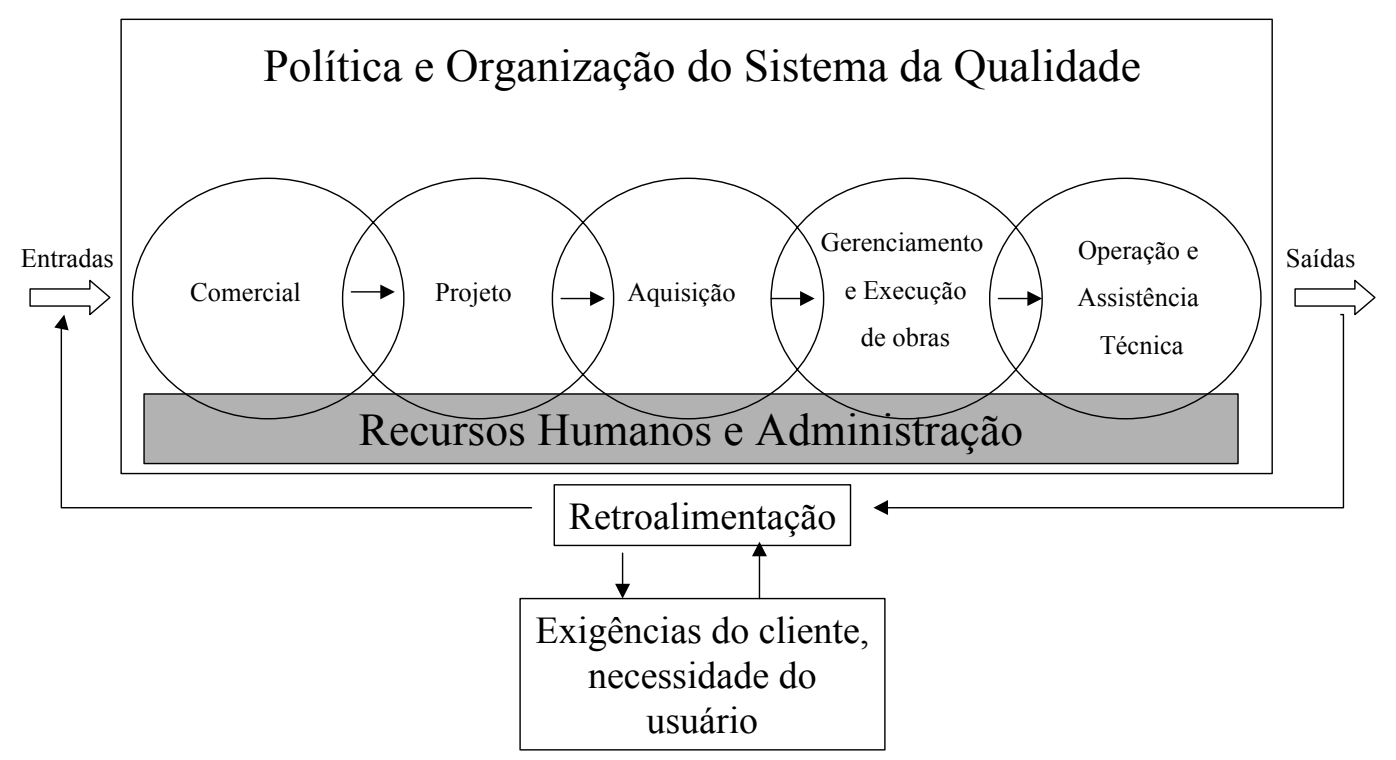

Figura 1 - Elementos do SGQ para empresas construtoras (Adaptação: PICCHI, 1993)

Reis (1998) coloca que os elementos que formam o Sistema da Qualidade, apresentados na Figura 1, estão dinamicamente relacionados entre si e isso significa que só atingirão as metas da Qualidade Total e o bom funcionamento da organização quando todos os setores trabalharem de forma integrada e coordenada, cada um com suas atribuições e responsabilidades, porém, sempre preocupados com a satisfação das necessidades e expectativas de seus clientes internos ou externos. 


\subsection{Histórico da Série ISO 9000}

Com o objetivo de entender o que é a série de normas intituladas ISO 9000, sua importância para as organizações e o motivo de sua existência, é necessário, num primeiro momento, investigarmos a sua história.

Andrade; Xavier (1996) colocam que nos anos pós Segunda Guerra Mundial, a situação da industria bélica na Europa e nos Estados Unidos da América era precária, isto porque a prioridade de produção visando à quantidade deteriorou profundamente a qualidade dos armamentos e serviços, comprometendo a segurança e integridade do seu próprio pessoal, face à falta de confiabilidade dos fornecedores.

No final dos anos 40 o Departamento de Defesa dos Estados Unidos reconheceram os benefícios de um Sistema de Gestão que transformou a industria japonesa. O sistema de padronização desenvolvido pelo Departamento de Defesa foi chamado de quality assurance segundo o qual as organizações envolvidas estabeleciam procedimentos para gerenciar todas as funções que afetavam a qualidade dos produtos manufaturados. 6

Seguindo a busca pelo desenvolvimento de padrões da qualidade criou-se as Normas Allied Quality Assurance Publication (AQAP) em 1970, as quais foram utilizadas pela Organização do Tratado do Atlântico Norte (OTAN). Com base nos benefícios obtidos com as Normas da AQAP, o Ministério da Defesa da Inglaterra e seus fornecedores observaram que a necessidade da aplicação de padrões para Sistema da Qualidade não se restringia apenas a armamentos e demais materiais bélicos. Era necessário abranger as demais indústrias fabricantes de bens de consumo e bens de capital.

No Reino Unido surgiu as Defense Standards (DEF.STAN.) normas das Forças Armadas sobre Sistemas da Qualidade, que deram base para a BS 5750 (British Standard) publicada em 1979.

\footnotetext{
${ }^{6}$ Informações obtidas do site: http://www.bsi-global.com acessado em 10/08/2003
} 
Neste mesmo ano nasce o grupo ISO TC 176 (Technical Committee da ISO para a qualidade), para elaborar Normas sobre Qualidade procurando uniformizar conceitos, padronizar modelos para garantia da qualidade e fornecer diretrizes para implantação da gestão da qualidade nas organizações. Só em 1987 as Normas são aprovadas constituindo a Série 9000. Esta foi baseada na última versão da Norma BS 5750 (1987) e aceita rapidamente como um padrão mundial para Sistemas da Qualidade.

Souza (1997) ainda coloca que tais normas eram utilizadas por grandes clientes compradores para qualificação de empresas fornecedoras. Entretanto, com o decorrer do tempo, a proliferação de normas dessa natureza e a crescente importância dada pelos clientes à questão da qualidade começaram a provocar sérios distúrbios nas trocas comerciais, uma vez que empresas fornecedoras se viram obrigadas a atender requisitos de sistemas da qualidade diferentes, conforme a norma utilizada para cada cliente.

De acordo com Souza (1997), os sistemas da qualidade foram utilizados inicialmente somente em situações contratuais, seguindo diversas normas que estabeleciam requisitos para os sistemas, adequados para países e setores industriais específicos. Surgiram assim, em diversos países, normas de sistemas da qualidade para o setor nuclear, aeronáutico, petrolífero e outros.

No final dos anos 80, as Normas da série ISO 9000 entraram no primeiro processo de revisão. A intenção desta primeira revisão foi corrigir as inconsistências e erros observados no decorrer da utilização e melhorar sua aplicabilidade para as organizações voltadas para a prestação de serviços. Resultou desse trabalho a série de normas ISO 9000, lançada em 1987 que teve uma pequena revisão em 1994 e em 2000 passou por uma reestruturação bem mais complexa e importante.

Para manter a eficácia da série ISO 9000, as normas são periodicamente revisadas buscando a evolução gradual no campo do gerenciamento da qualidade. O ISO/TC 176 monitora os usuários das normas para determinar como elas podem ser aprimoradas, conhecendo as necessidades e expectativas destes usuários, visando à próxima revisão das normas, que se dá aproximadamente a cada cinco anos. (Fonte: http://www.iso.ch acessado em 04 de abril de 2003) 


\subsection{Panorama da qualidade}

A exemplo do que aconteceu com outros aspectos do universo empresarial, a década de 90 representou um grande avanço para a qualidade no Brasil. Essa década iniciouse no Brasil com a tradução em 1990 pela ABNT das normas ISO 9000, as quais haviam sido lançadas internacionalmente em 1987. No primeiro momento, houve por parte das empresas (inclusive das grandes multinacionais) muito interesse e curiosidade, porém poucos possuíam informações confiáveis sobre essa série de normas recém-lançada.

Mas, rapidamente, as normas ISO 9000 alcançaram um destaque muito grande, mercê da feliz confluência de alguns fatores. Um deles foi o Programa Brasileiro da Qualidade e Produtividade - PBQP, o qual também nascia com a nova década. De forma inteligente, o PBQP articulava as diversas empresas estatais e governamentais - Petrobrás, empresas dos sistemas Eletrobrás e Telebrás, entre outras, utilizando seu poder de compra para alavancar o desempenho dos fornecedores, via exigência de sistemas de garantia da qualidade conforme as normas ISO 9000. Para mostrar a importância dessa articulação, o governo brasileiro era, na época, o maior comprador em todos os segmentos industriais.

No âmbito internacional, os países pertencentes à Comunidade Econômica Européia (CEE), atual União Européia, estabeleceram a exigência de modelos de certificação para a circulação de um grande número de produtos em seu território. Esses modelos de certificação tinham a necessidade de sistemas da qualidade compatíveis com um dos três modelos de garantia da qualidade ISO 9000. Vale lembrar que entre os 12 países da então CEE estavam (como ainda estão) quatro países membros do G-7 (Alemanha, França, Inglaterra e Itália) o que dá uma idéia do que representou essa exigência.

Assim, pressionadas pelos mercados interno e externo, muitas empresas brasileiras buscaram a sua certificação e, dessa forma, o Brasil passou a ter maior visibilidade no cenário internacional da qualidade. Em paralelo a esse processo mercadológico, o CB-25/ABNT (Comitê Brasileiro da Qualidade) desenvolvia um trabalho articulando organismos governamentais e empresas privadas com o objetivo de ocupar espaços 
em vários grupos de trabalho do ISO/TC-176 e, com isso, aumentar a influência nas suas decisões.

Paralelamente ao fenômeno ISO 9000 citado, em 1992 foi criado o Prêmio Nacional da Qualidade, estabelecendo um referencial de excelência para a área e indicando caminhos para aquelas empresas que tinham aspirações mais amplas em relação aos seus sistemas de gestão.

A qualidade em sua concepção mais abrangente, como a que se apresenta na definição da norma NBR ISO 8402:1997, como sendo "a totalidade das características de uma entidade que determina a sua capacidade de atender necessidades explícitas e implícitas", ocupa um papel singular e ainda não de todo compreendido pelos gestores de empresas.

Alves (2001) coloca que a gestão da qualidade alcança os níveis estratégicos, táticos e operacionais das empresas, cruza as múltiplas funções nela executadas e abrange fatores tecnológicos, organizacionais e humanos que afetam o seu desempenho. Portanto, a qualidade pode (ou, deve) estar incluída no processo de gestão estratégica da empresa, ser associada à lucratividade e ao desempenho competitivo, sendo definida de acordo com o ponto de vista do cliente e de demandas impostas por outros atores do ambiente de atuação da empresa.

Pela sua natureza multidisciplinar, a qualidade é a (única) dimensão que possibilita a integração de todos os níveis, fatores e aspectos da empresa, como propõe implicitamente o "modelo" definido pelos critérios de excelência do Prêmio Nacional da Qualidade. Esse “modelo" integra aspectos mercadológicos, financeiros, humanos, tecnológicos e organizacionais, resultando num sistema de gestão com enfoque sistêmico (na acepção exata da palavra). Ressalte-se que este tipo de sistema de gestão é extremamente importante no momento atual, na medida em que disponibiliza recursos efetivos para fazer frente aos desafios impostos à empresa por um ambiente que é complexo, extremamente competitivo e que muda rápida e continuamente. 
Como conseqüência do desenvolvimento na sua concepção ocorrida nos anos 90 , desde as normas ISO até os "critérios de excelência", a qualidade foi inserida no universo da administração. Ao contrário do que ocorria até a década de 80 , quando a qualidade era vista como sendo simplesmente um conjunto de métodos e ferramentas para resolver problemas de produção, a sua importância é hoje reconhecida por profissionais e teóricos da área de administração de empresas. Alves (2001) coloca que isso pode ser constatado por meio de vários artigos e livros publicados naquela década, os quais passavam a registrar o seu papel dentro da Teoria das Organizações e tendo Deming e Juran como principais referências, colocaram-nos no mesmo patamar em que se encontram os grandes teóricos e pensadores da administração do século XX.

\subsection{A Série ISO 9000:1994}

A série NBR ISO 9000:1990, que foi a primeira versão traduzida pela ABNT passou por uma pequena revisão em 1994. A versão de 1994 como a versão anterior, não trata de especificações de produtos e sim são normas sistêmicas, que estabelecem os elementos do sistema de gestão e da garantia da qualidade a serem consideradas pelas empresas.

De acordo com Maranhão (1996), as normas ISO 9000 são normas sistêmicas, e devem ser aplicadas na empresa como um todo e não a produtos, materiais ou serviços.

A Figura 2 mostra como estava distribuída a família de normas ISO 9000 versão 1994, que seguiu a mesma estrutura da versão de 1990. 


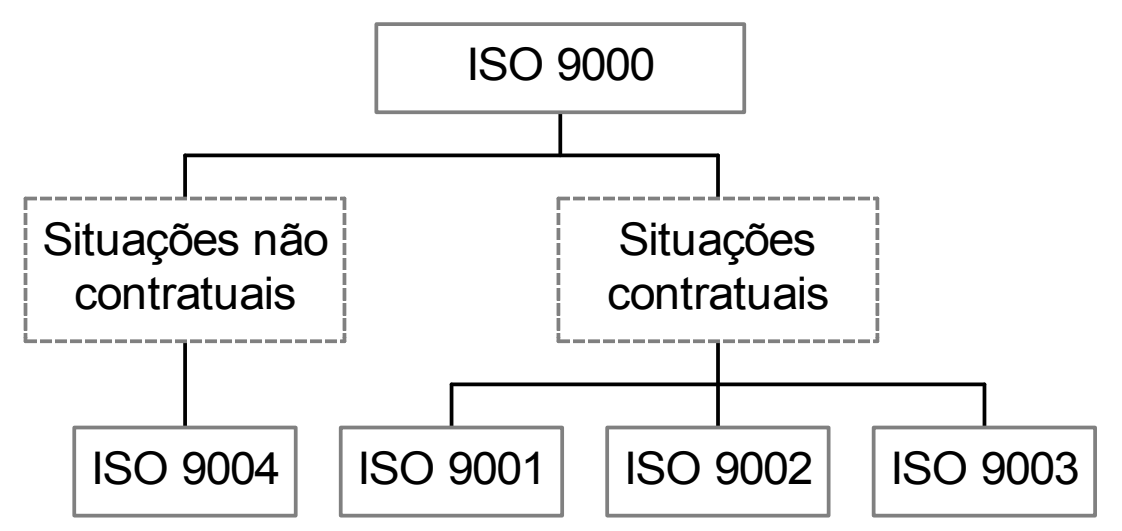

Figura 2 - Estrutura das Série ISO 9000:1994 (Fonte: MARANHÃO, 1996)

Segundo Maranhão (1996), as normas ISO 9001, 9002 ou 9003 fixavam os requisitos, exigências ou itens de verificação dos contratos entre as organizações e clientes.

Em função da atividade da empresa, seu Sistema da Qualidade poderia ser certificado de acordo com a ISO 9001, ISO 9002 ou ISO 9003.

O Brasil, por meio da Associação Brasileira de Normas Técnicas - ABNT, adotou a mesma numeração da série ISO 9000, chamando-a de série NBR ISO 9000.

A NBR ISO 9000 - Normas de Gestão da Qualidade e Garantia da Qualidade Diretrizes para seleção e uso (parte 1) e Diretrizes gerais para aplicação das NBR ISO 9001, NBR ISO 9002 e NBR ISO 9003 (parte 2), tem como objetivos esclarecer as diferenças e a inter-relação entre os principais conceitos da qualidade e fornecer diretrizes para a seleção e uso das outras normas da série, que podem ser utilizadas para Gestão da Qualidade Interna e Garantia da Qualidade Externa.

A NBR ISO 9001 especifica requisitos do Sistema da Qualidade e, segundo Souza (1997), é utilizada quando um contrato entre duas partes exige a demonstração da capacidade do fornecedor para projetar e fornecer produtos. Os requisitos especificados nesta norma destinam-se, primordialmente, à prevenção de nãoconformidades em todos os estágios, desde o projeto até à assistência técnica. De acordo com Reis (1998), esta Norma é a mais abrangente de todas e destina-se a contratos cujo interesse é proporcionar proteção e garantia da Qualidade em todas as fases das atividades técnicas da empresa, desde o projeto até a assistência técnica. 
Andrade; Xavier (1996) apontam ainda que esta norma é o padrão para os sistemas da qualidade relativos a projeto, desenvolvimento, produção, inspeção e ensaios, instalação e serviços associados. Em outras palavras, esta norma é adequada para organizações que fornecem produtos com base em projeto próprio; que produzem e entregam seus produtos aos clientes. Se a organização também agrega às suas atividades a instalação e os serviços associados, estes também são cobertos pela norma.

Para Souza (1997), a NBR ISO 9002 especifica requisitos do Sistema da Qualidade para uso no qual um contrato entre duas partes exige a demonstração da capacidade do fornecedor para controlar os processos que determinam a aceitabilidade do produto fornecido. Os requisitos especificados nesta norma destinam-se, primordialmente, à prevenção e à detecção de qualquer não-conformidade durante a produção e instalação e na implementação de meios para prevenir a sua reincidência. Reis (1998) coloca ainda que esta norma destina-se a proporcionar abrangência de proteção da qualidade de todo o ciclo produtivo, exceto o projeto e desenvolvimento do produto. Segundo Andrade; Xavier (1996) ela é similar à 9001, mas abrange apenas produção, inspeção e ensaios, instalação e serviços associados. Projeto não faz parte da abrangência desta norma.

A NBR ISO 9003 especifica requisitos do Sistema da Qualidade para uso no qual um contrato entre duas partes requer a demonstração da capacidade do fornecedor em detectar e controlar a disposição de qualquer produto não-conforme, durante a inspeção e ensaios finais. É aplicável em situações contratuais quando a conformidade do produto aos requisitos especificados pode ser obtida pela documentação adequada de determinada capacidade do fornecedor, para inspeção e ensaios efetuados no produto fornecido. Esta norma destina-se a empresas que focam seu sistema da qualidade apenas nas inspeções e ensaios finais do produto (Reis, 1998). Para Andrade; Xavier (1996) esta norma tem o objetivo, como uma das normas da série, de abranger organizações envolvidas apenas com inspeção e ensaios. Contém todos os requisitos da 9001, exceto projetos, aquisição, controle de processos e serviços associados. Como resultado dessas exclusões, os demais requisitos ficaram menos rígidos. A ISO 9003 não era muito adequada como norma 
de Sistema da Qualidade para muitas organizações e, dessa maneira, foi pouco utilizada.

A NBR ISO 9004 destina-se a organizações que desejam implantar espontaneamente um Sistema de Gestão da Qualidade. Descreve um conjunto básico de elementos através do qual o Sistema de Gestão da Qualidade pode ser desenvolvido. O sistema da qualidade aplica-se tipicamente a todas as atividades relativas à qualidade de um produto ou serviço, interagindo com as mesmas. Ele envolve todas as fases, desde a identificação inicial até a satisfação final dos requisitos e expectativas do cliente. Sendo assim o usuário dessa norma pode selecionar os elementos do Sistema da Qualidade que são adequados à sua realidade empresarial. (CTE, 1995)

Souza (1997) diz que dentre as normas da série para fins contratuais, a NBR ISO 9001 é a mais completa, tendo as demais (NBR ISO 9002 e NBR ISO 9003) um nível de exigência decrescente.

Na versão de 1994, a seção 4 descreve os elementos ou requisitos do sistema da qualidade, sendo:

\section{$\checkmark$ Seção 4.1 - Responsabilidade pela Administração: Descreve as} responsabilidades da administração da organização para com os objetivos e a política da qualidade, bem como o seu compromisso com a qualidade; inclui também esta seção a responsabilidade por parte da Administração, pela realização da análise crítica de todo o sistema da qualidade, buscando verificar a contínua adequação e eficácia em atender aos requisitos da Norma;

$\checkmark$ Seção 4.2 - Sistema da Qualidade: Requisitos para a estruturação e documentação do Sistema da Qualidade, incluindo o planejamento para desenvolvimento e manutenção do sistema;

Seção 4.3 - Análise Crítica de Contrato: Descreve os requisitos para a organização assegurar que todos os contratos, propostas ou pedidos estão de acordo com o solicitado e atendem aos seus requisitos, assim como àqueles do cliente; inclui também a identificação de como a emenda a um contrato é feita e transferida às funções envolvidas; 
$\checkmark$ Seção 4.4 - Controle de Projeto: Descreve os requisitos para a organização em assegurar que os produtos e serviços são projetados para atender às necessidades dos clientes e da organização; inclui o planejamento para desenvolvimento do projeto, requisitos de entrada e saída;

Seção 4.5 - Controle de Documentos: Descreve os requisitos para o controle e manutenção de todas as exigências relativas ao Sistema, incluindo a necessidade de se definir responsáveis pela análise e aprovação de toda a documentação, controle de emissões e revisões e identificação da natureza das alterações nos documentos ou anexos apropriados;

Seção 4.6 - Aquisição: Descreve requisito para a organização assegurar que todos os materiais e serviços adquiridos, que afetem a qualidade do produto, estejam de acordo com os requisitos especificados, incluindo a obrigatoriedade de qualificação e avaliação de seus fornecedores;

\section{Seção 4.7 - Controle de Produto Fornecido pelo Cliente: Descreve os} requisitos para controle, que devem ser aplicados quando o cliente se torna um fornecedor, não eximindo a organização de verificar, armazenar e manter o produtor fornecido dentro dos critérios estabelecidos;

Seção 4.8 - Identificação e Rastreabilidade do Produto: É a exigência de identificar materiais, produtos e serviços em todos os estágios do processo e, se necessário, a habilidade de rastrear o produto individualmente ou em lotes;

$\checkmark$ Seção 4.9 - Controle de Processo: Trata da necessidade de se aplicar controles nos processos de produção, instalação e na prestação de serviços, para assegurar que os requisitos especificados são atendidos; inclui a necessidade de uso de equipamentos adequados e apresenta a situação onde os resultados dos processos não podem ser plenamente verificados, sendo que nestes casos a Norma exige que estes processos sejam executados por operadoras especializadas e monitorados continuamente;

Seção 4.10 - Inspeção e Ensaios: Descreve os requisitos a serem aplicados na inspeção e ensaios de matérias-primas e materiais, processo (incluindo 
serviços) e produto final, para assegurar a conformidade com as solicitações especificadas;

$\checkmark$ Seção 4.11 - Controle de Equipamentos de Medição, Inspeção e Ensaios: São requisitos que tratam da necessidade da organização verificar a eficácia e exatidão dos resultados fornecidos pelos equipamentos de medição e inspeção; inclui também a necessidade da organização em identificar todos os equipamentos de inspeção e medição que possam afetar a qualidade do produto, aferindo-os a intervalos definidos;

Seção 4.12 - Situação de Inspeção e Ensaios: Descrevem requisitos em que se exige que todos os produtos e serviços sejam identificados quanto à sua aprovação ou não em relação às inspeções e aos ensaios estabelecidos, buscando assegurar que somente produtos ou serviços aprovados pela inspeção e ensaios sejam liberados, utilizados ou instalados;

Seção 4.13 - Controle de Produto Não-Conforme: Descreve a necessidade de isolar e prevenir da utilização todos os materiais, produtos e serviços que não estejam de acordo com os requisitos estabelecidos; inclui a necessidade da análise crítica deste produto para a correção, reclassificação ou rejeição deste produto ou serviço;

$\checkmark$ Seção 4.14 - Ação Corretiva e Preventiva: Descreve requisitos para tomada de ações visando a correção de processos que não estão em bom funcionamento e a criação de medidas para assegurar que, no futuro, as falhas encontradas não voltem mais a ocorrer;

\section{Seção 4.15 - Manuseio, Armazenamento, Estoque, Preservação e}

Entrega: Descreve os requisitos para manter a qualidade dos materiais, produtos em processo e produto final até chegarem ao cliente; asseguram também que os serviços cheguem ao cliente de acordo com os requisitos especificados;

Seção 4.16 - Controle de Registros da Qualidade: É o requisito que estabelece a manutenção de todos os registros da qualidade, incluindo a 
necessidade da criação de parâmetros para a identificação, coleta, indexação, acesso e disposição após o período de retenção destes registros da qualidade;

$\checkmark$ Seção 4.17 - Auditorias Internas da Qualidade: Descrevem requisito sobre as auditorias na organização, que devem ser planejadas, implementadas e documentadas, para verificar se as atividades da qualidade e respectivos resultados estão em conformidade com as disposições planejadas e para determinar a eficácia do sistema da qualidade;

Seção 4.18 - Treinamento: Descreve que a organização tem a necessidade de providenciar treinamento a todos os envolvidos em funções que influenciam na qualidade, mantendo pessoal capacitado e qualificado para determinadas funções;

$\checkmark$ Seção 4.19 - Serviços Associados: É o requisito que traz a necessidade de assegurar que os serviços pós-entrega atendam aos requisitos especificados;

Seção 4.20 - Técnicas Estatísticas: Descreve que a organização deve identificar as técnicas estatísticas requeridas para estabelecimento, controle e verificação da capabilidade ${ }^{7}$ do processo e das características do produto.

7 Capabilidade é a amplitude total da variação inerente a um processo estável, determinada utilizando-se de dados provenientes de cartas de controle. Definição obtida do site: http://www2.ciesp.org.br/qualidade/mainglos.htm acessado em 15/08/2003 
A seguir é apresentada a Tabela 1, na qual demonstra-se quais requisitos são exigidos em cada uma das Normas da série ISO 9000 versão 1994.

Tabela 1: Requisitos da ISO 9000 aplicáveis em cada uma das normas da Série (Fonte: ABNT, 1994)

\begin{tabular}{|c|c|c|c|}
\hline \multirow{2}{*}{ Requisitos } & \multicolumn{3}{|c|}{ Norma ISO } \\
\hline & 9001 & 9002 & 9003 \\
\hline 4.1 - Responsabilidade pela Administração & $\mathbf{X}$ & $\mathbf{X}$ & $\mathbf{X}$ \\
\hline 4.2 - Sistema da Qualidade & $\mathbf{X}$ & $\mathbf{X}$ & $\mathbf{X}$ \\
\hline 4.3 - Análise Crítica de Contrato & $\mathbf{X}$ & $\mathbf{X}$ & \\
\hline 4.4 - Controle de Projeto & $\mathbf{X}$ & & \\
\hline 4.5 - Controle de Documentos & $\mathbf{X}$ & $\mathbf{X}$ & $\mathbf{X}$ \\
\hline 4.6 - Aquisição & $\mathbf{X}$ & $\mathbf{X}$ & \\
\hline 4.7 - Controle de Produto Fornecido pelo Cliente & $\mathbf{X}$ & $\mathbf{X}$ & \\
\hline 4.8 - Identificação e Rastreabilidade do Produto & $\mathbf{X}$ & $\mathbf{X}$ & $\mathbf{X}$ \\
\hline 4.9 - Controle de Processo & $\mathbf{X}$ & $\mathbf{X}$ & \\
\hline 4.10 - Inspeção e Ensaios & $\mathbf{X}$ & $\mathbf{X}$ & $\mathbf{X}$ \\
\hline 4.11 - Controle de Equipamentos de Medição, Inspeção e Ensaios & $\mathbf{X}$ & $\mathbf{X}$ & $\mathbf{X}$ \\
\hline 4.12 - Situação de Inspeção e Ensaios & $\mathbf{X}$ & $\mathbf{X}$ & $\mathbf{X}$ \\
\hline 4.13 - Controle de Produto Não-Conforme & $\mathbf{X}$ & $\mathbf{x}$ & $\mathbf{X}$ \\
\hline 4.14 - Ação Corretiva e Preventiva & $\mathbf{X}$ & $\mathbf{X}$ & \\
\hline 4.15 - Manuseio, Armazenamento, Estoque, Preservação e Entrega & $\mathbf{X}$ & $\mathbf{X}$ & $\mathbf{X}$ \\
\hline 4.16 - Controle de Registros da Qualidade & $\mathbf{X}$ & $\mathbf{X}$ & $\mathbf{X}$ \\
\hline 4.17 - Auditorias Internas da Qualidade & $\mathbf{X}$ & $\mathbf{X}$ & \\
\hline 4.18 - Treinamento & $\mathbf{X}$ & $\mathbf{X}$ & $\mathbf{X}$ \\
\hline 4.19 - Serviços Associados & $\mathbf{X}$ & $\mathbf{X}$ & \\
\hline 4.20 - Técnicas Estatísticas & $\mathbf{X}$ & $\mathbf{X}$ & $\mathbf{X}$ \\
\hline
\end{tabular}

Para melhor visualizar quais são as principais diferenças em termos de níveis de exigência, é apresentada a Tabela 2. 
Tabela 2: Correspondência entre os elementos do SQ (Fonte: CTE, 1995)

\begin{tabular}{|c|c|c|c|}
\hline \multirow{3}{*}{$\begin{array}{l}\text { Elementos do Sistema da Qualidade (ISO 9004) } \\
\text { Legenda: Requisito pleno } \\
\star \text { Menos rigoroso que na ISO } 9001 \\
* \text { Menos rigoroso que na ISO } 9002\end{array}$} & \multicolumn{3}{|c|}{$\begin{array}{l}\text { Elementos correspondentes } \\
\text { na norma }\end{array}$} \\
\hline & ISO & ISO & ISO \\
\hline & 9001 & 9002 & 9003 \\
\hline Responsabilidade da administração & $\theta$ & is & $*$ \\
\hline Princípios do Sistema da Qualidade & $\theta$ & $\theta$ & ts \\
\hline Auditoria do Sistema da Qualidade (interna) & $\theta$ & ts & - \\
\hline Economia (consideração sobre custos relacionados com qualidade). & - & - & - \\
\hline Qualidade em marketing (análise crítica do contrato) & $\theta$ & 0 & - \\
\hline Qualidade na especificação e projeto (controle de projeto) & $\theta$ & - & - \\
\hline Qualidade na aquisição (compras) & $\theta$ & $\theta$ & - \\
\hline Qualidade na produção (controle de processo) & $\theta$ & $\theta$ & - \\
\hline Controle de produção & $\theta$ & $\theta$ & - \\
\hline $\begin{array}{l}\text { Controle e rastreabilidade de materiais (identificação e } \\
\text { rastreabilidade de produto) }\end{array}$ & $\theta$ & $\theta$ & $\vec{t}$ \\
\hline Controle do estado de verificação (situação da inspeção e ensaios). & $\theta$ & $\theta$ & th \\
\hline Verificação de produto (inspeção e ensaios) & $\theta$ & $\theta$ & ts \\
\hline $\begin{array}{l}\text { Controle de equipamento de medição e ensaios (equipamento de } \\
\text { inspeção, medição e ensaio) }\end{array}$ & $\theta$ & $\theta$ & $\dot{t}$ \\
\hline Não-conformidade (controle de produto não-conforme) & $\theta$ & $\theta$ & ts \\
\hline Ação corretiva & $\theta$ & $\theta$ & is \\
\hline $\begin{array}{l}\text { Funções de manuseio e pós-produção (manuseio, armazenamento, } \\
\text { embalagem e expedição) }\end{array}$ & $\theta$ & $\theta$ & th \\
\hline Serviços pós-venda & $\theta$ & - & - \\
\hline Documentação e registros da qualidade (controle de documentos) & $\theta$ & $\theta$ & ts \\
\hline Registros da qualidade & $\theta$ & $\theta$ & $\dot{t}$ \\
\hline Pessoal (treinamento) & $\theta$ & $\theta$ & $*$ \\
\hline Segurança e responsabilidade pelo fato do produto & - & - & - \\
\hline Uso e método estatístico (técnicas estatísticas) & $\theta$ & $\theta$ & it \\
\hline Produtos fornecidos pelo cliente & $\theta$ & $\theta$ & - \\
\hline
\end{tabular}

Segundo Souza (1997) é importante ressaltar que as normas NBR ISO 9001, NBR ISO 9002 e NBR ISO 9003 têm por objetivo dar confiança ao comprador, em situações contratuais, de que os procedimentos foram seguidos, devendo ser consideradas como requisitos mínimos para manter um certo nível de qualidade da organização. As empresas que pretendem melhorar a sua competitividade devem, 
adicionalmente, desenvolver um sistema de gestão da qualidade centrado na satisfação do cliente, que pode ser fundamentado na norma ISO 9004.

\subsection{A Série ISO 9000:2000}

No dia 15 de dezembro de 2000, foi finalmente publicada a nova série de normas ISO 9000, após mais de quatro anos de discussões.

O sistema normativo adotado pela ISO pressupõe a atualização periódica das normas, principalmente por se tratar de uma norma não técnica, que envolve questões de gestão organizacional em contínuo processo de mudança. Em relação à edição inicial de 1987, a revisão de 1994 - ainda em vigor para fins de certificação - resolveu pequenos desentendimentos e corrigiu falhas conceituais simples, sem profundas alterações de formato ou de conceitos. Mesmo assim, na época a revisão causou algumas dificuldades para as organizações que já estavam certificadas ou em via de se certificarem.

Uma das questões que se coloca é como as organizações já certificadas devem agir para se adaptarem, mantendo seu certificado e usufruir os benefícios com a adoção das modernas ferramentas de gestão da revisão. Na realidade, a travessia, ou transição, que uma organização certificada terá de efetuar para atender à versão 2000 do modo mais simples e proveitoso, deve ser considerada como um novo projeto, tão importante quanto aquele de implantação inicial, onde se aproveitarão as conquistas da versão atual e serão concebidas as mudanças visando a conseguir os benefícios e as melhorias introduzidas com a nova versão. Este projeto não pode ser tratado com simplicidade, nem deve ser deixado para a última hora, sob o risco de não se conseguir chegar a bons resultados.

Uma das situações que certamente deixa ou deixará muitos gerentes da qualidade preocupados é retornar de um curso aberto sobre a nova norma e constatar que, na realidade, quem deveria ter feito o curso era seu diretor. Isto porque as mudanças mais significativas não estão na produção, mas sim na gestão organizacional, na administração de recursos e das melhorias que normalmente estão sob poder e responsabilidade da alta direção. 
De acordo com Branchini (2002), muito se tem escrito e falado sobre a nova versão da ISO 9000; contudo, a verdade é que ela está trazendo mudanças significativas com relação à versão de 1994, pois o seu foco, agora, não está direcionado apenas para assegurar a qualidade do produto, mas também inclui a necessidade de a empresa demonstrar sua capacidade de atingir a satisfação do cliente, com a aplicação da melhoria contínua de seus processos e da prevenção de nãoconformidades. Em vez de um sistema de garantia da qualidade, a norma passa a ser caracterizada como um sistema de gestão da qualidade.

Usuários de todas as partes do mundo, ouvidos através de uma pesquisa conduzida pela própria ISO, foram muito críticos em relação à ISO 9001:1994, classificando-a como "pesadona", "confusa" e com "fortes tendências à manufatura". Esses aspectos foram detalhadamente analisados, em conjunto com as sugestões dos usuários que queriam uma norma voltada para os processos da organização, para seus clientes e para a melhoria contínua do desempenho do Sistema de Gestão da Qualidade (SGQ). Com tudo isto em mente, o Subcomitê (SC2) do TC 176 da ISO desenvolveu um modelo de processo para retratar os requisitos genéricos de um SGQ, como mostrado na Figura 3.

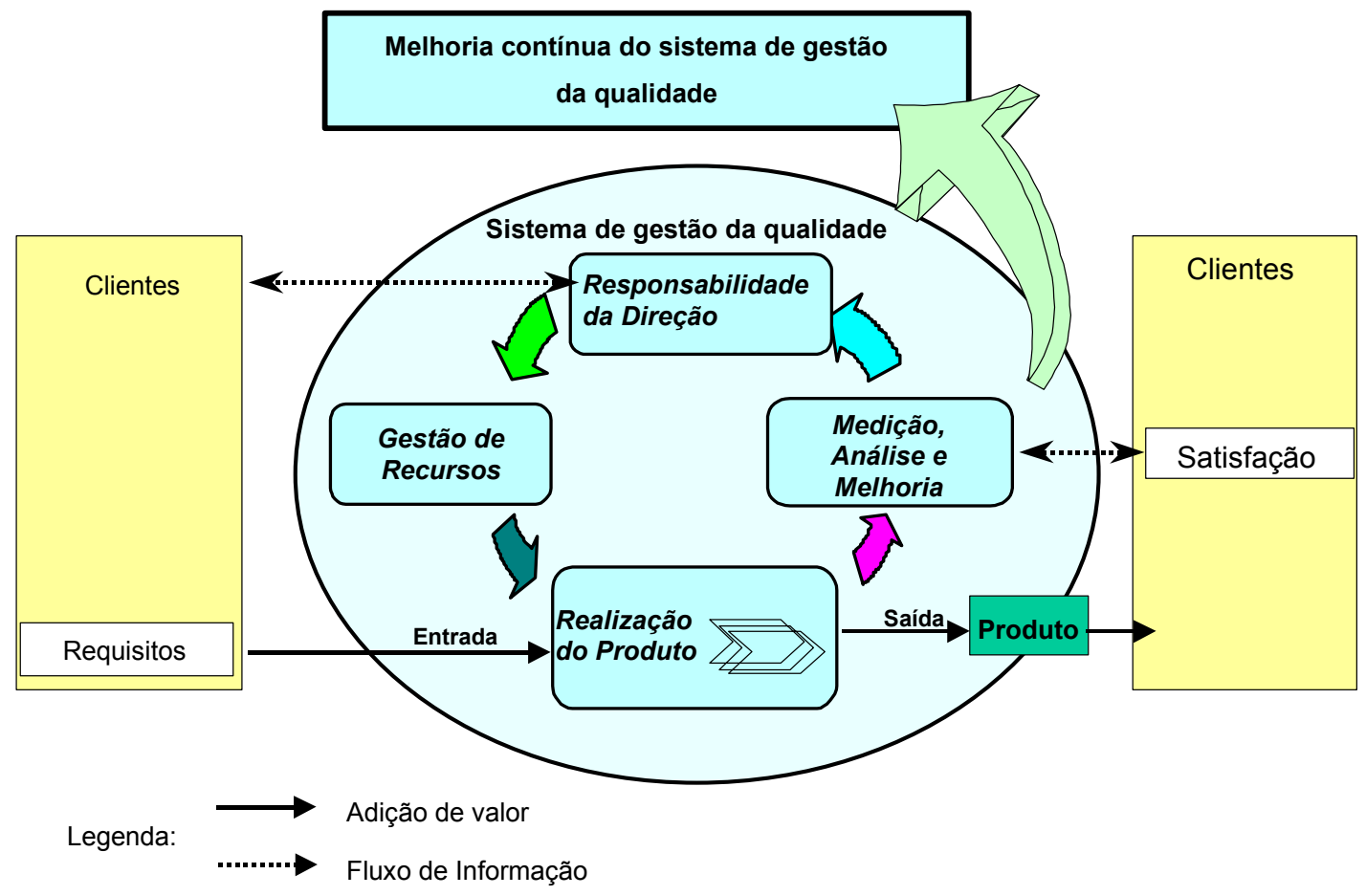

Figura 3 - Modelo de um SGQ baseado em processo (Fonte: ABNT, 2000) 
De acordo com Cysne (2001), apresentada desta forma a figura adotada na nova versão da ISO 9000 parece um tanto quanto confusa devido ao excesso de informações, ainda mais quando comparada à ISO 14001 (Figura 4) que possui um modelo mais simples, que apresenta o ciclo PDCA (Plan-Do-Check-Act) bem fácil de ser visualizado.

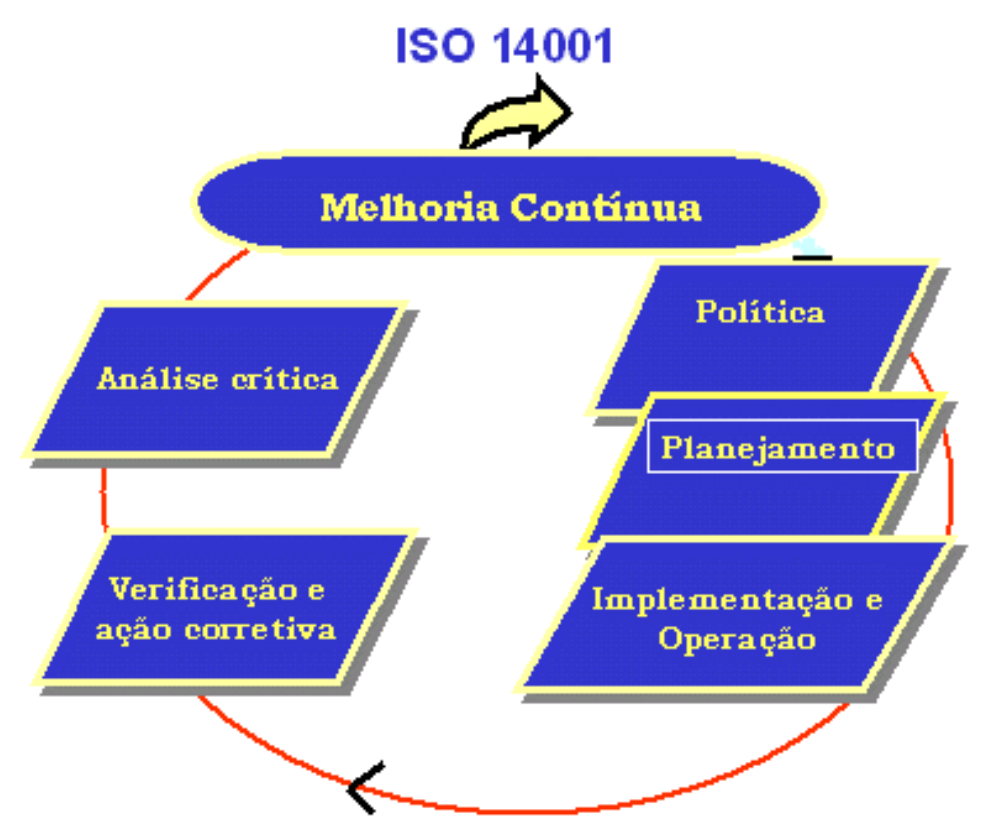

Figura 4 - Modelo de Sistema de Gestão proposto pela ISO 14001:1996 (Fonte: ABNT, 1996)

Ainda segundo Cysne (2001) uma abordagem que facilita a compreensão desta figura é trabalhá-la passo a passo. O primeiro passo (Figura 5) é fácil de entender se levar em conta o fluxo básico de um processo. Para a fabricação de um produto (ou serviço), temos as entradas sendo transformadas através da Realização do produto em saídas que nada mais são que os próprios produtos fabricados. Este é um esquema básico que qualquer empresa no mundo utiliza.

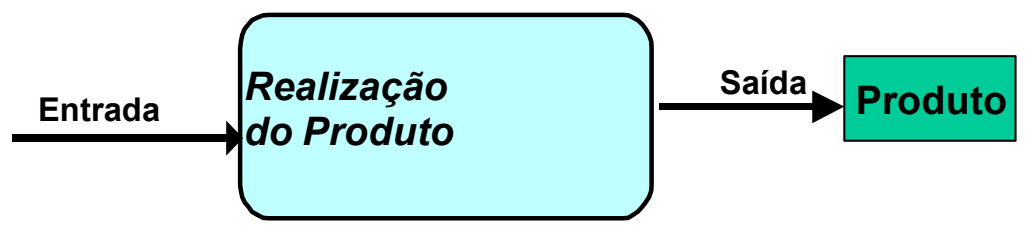

Figura $5-1^{\circ}$ Passo: Fluxo básico de processo

O segundo passo (Figura 6) aparentemente é igual ao primeiro, porém a pequena diferença é que não só os processos finais (que geram os produtos) devem ser levados em consideração, mas também todos os processos que estejam ligados ao 
sistema de gestão da qualidade e que influem na qualidade estabelecida para o produto. Por isso aparecem na figura os polígonos na caixa de Realização do produto. Esta preocupação com os demais processos mostra que todos eles devem trabalhar de forma harmônica com a Realização do produto.

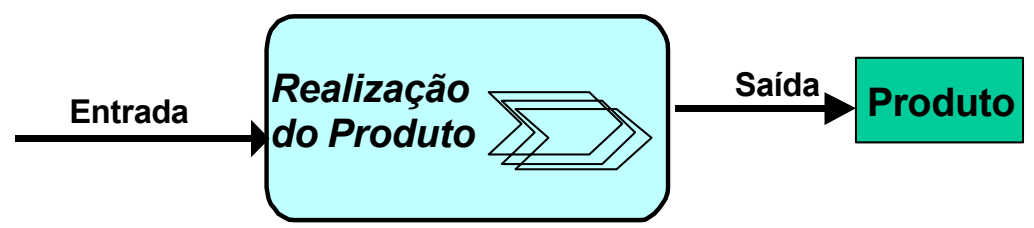

Figura 6 $-2^{\circ}$ Passo: Processos internos ao fluxo básico

O terceiro passo (Figura 7) apresenta uma das grandes mudanças da ISO nesta revisão. Na versão de 1994 a satisfação do cliente estava "escondida" na norma. Nesta revisão, os clientes ganham destaque. Eles estão antes da Realização do produto, informando quais são os requisitos requeridos ao sistema, e na saída, para que sua a satisfação seja atendida.

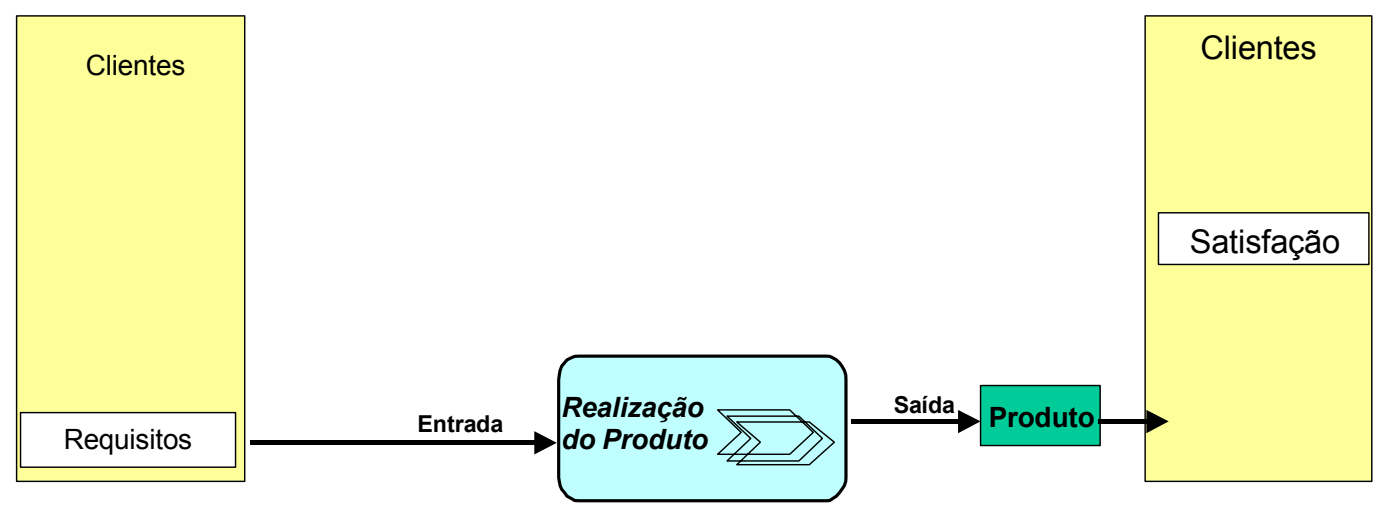

Figura $7-3^{\circ}$ Passo: Importância do Cliente na revisão 2000 da ISO 9000

No quarto passo (Figura 8) é introduzido o ciclo de qualidade nas demais etapas. A norma reforça que são importantes a Realização do Produto e a voz do cliente mas isso deve ser realizado através de um planejamento coerente (Responsabilidade da Direção e Gestão de Recursos ) e com Medição, análise e melhoria de todo o sistema de gestão da qualidade. Este é um ponto que garante a continuidade do sistema. 


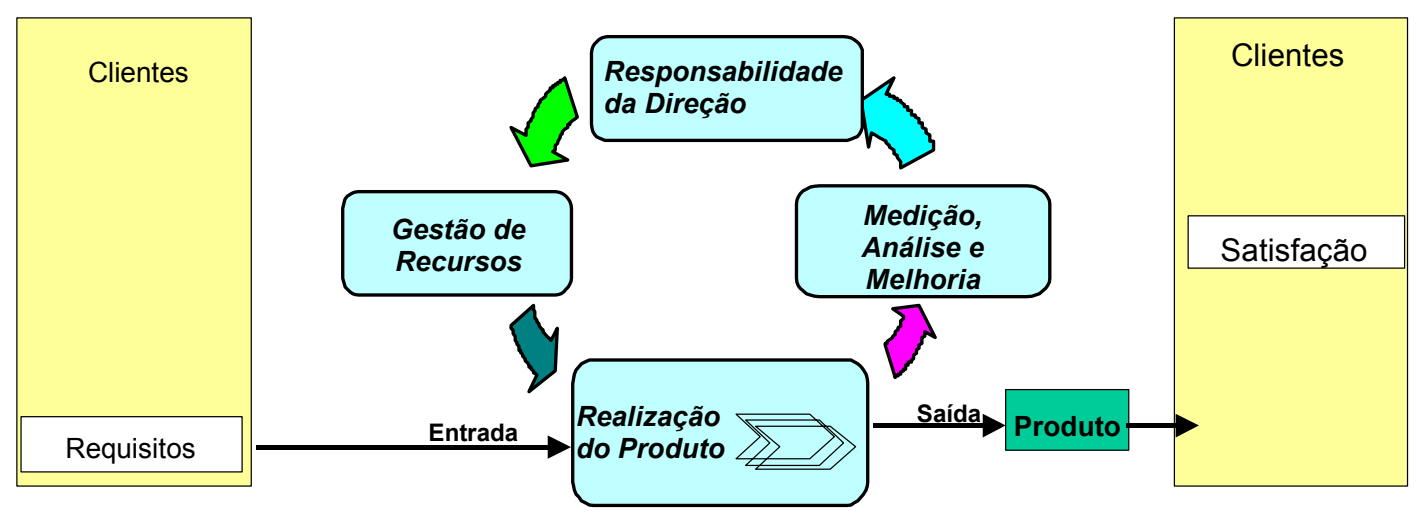

Figura 8-4 ${ }^{\circ}$ Passo:Introdução do ciclo da qualidade na Realização do Produto

No quinto passo (Figura 9) a norma apresenta uma outra grande mudança, que é a introdução da Melhoria Contínua. Este conceito promove a renovação e atualização do sistema de gestão da qualidade permitindo que ele evolua com o tempo.

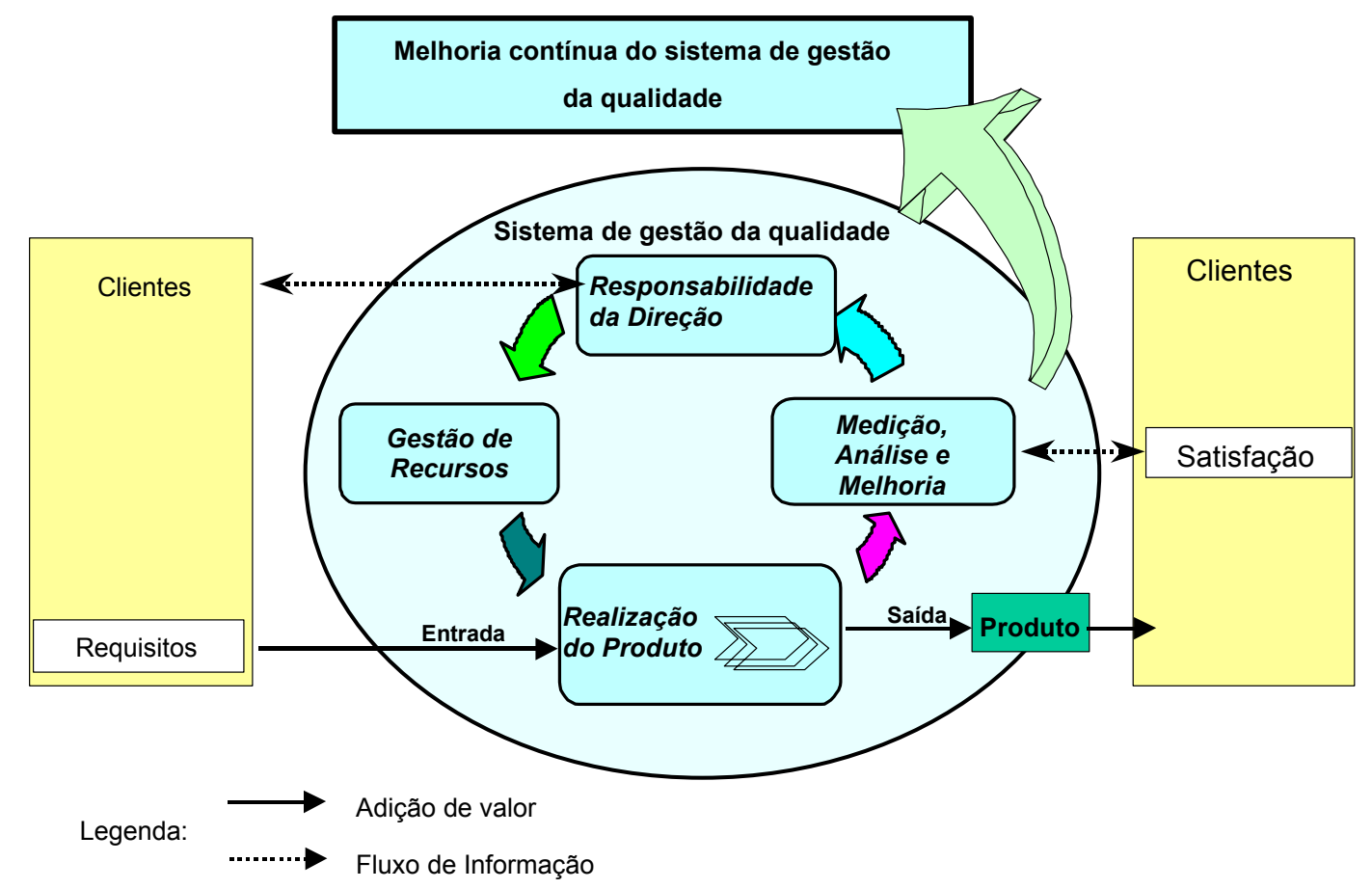

Figura 9- $5^{\circ}$ Passo: Melhoria contínua aplicada ao SGQ

Assim, com esta abordagem, fica mais fácil o entendimento da figura adotada pela ISO 9000:2000 em toda a sua totalidade e a visualização do modelo de processo proposto por esta revisão. 
A série ISO 9000:2000 está estruturada da seguinte forma:

$\checkmark$ ISO 9000:2000 - Sistema de gestão da qualidade - Fundamentos e Vocabulários;

$\checkmark$ ISO 9001:2000 - Sistema de gestão da qualidade - Requisitos;

$\checkmark$ ISO 9004:2000 - Sistema de gestão da qualidade - Diretrizes para melhoria do desempenho.

A revisão 2000 se caracteriza pela redução do número de normas da série, pela existência de requisitos explícitos para a medição da satisfação dos clientes, pela melhoria contínua e também por uma nova abordagem que privilegia os processos organizacionais. A nova série estabelece oito princípios fundamentais que levam em conta a concepção mais atualizada de um sistema de gestão da qualidade.

Dentro deste contexto a nova versão toma por base os seguintes princípios de gestão da qualidade.

\section{Princípio 1 - Foco no cliente}

Determina que a organização deve ter processos específicos para identificar os requisitos dos clientes, assim como, medir a satisfação do cliente para verificar seu cumprimento.

Os requisitos dos clientes podem ser identificados através de diversas fontes, tanto de tipo pro-ativo - através de pesquisas de mercado, dinâmicas de grupo e testes de mercado - como de tipo reativo - através de análise dos dados de devoluções, reclamações e/ou a participação de mercado dos concorrentes.

\section{$\checkmark$ Princípio 2-Liderança}

Dá maior ênfase ao papel de liderança da Alta Direção na determinação das políticas e práticas englobadas no processo de qualidade da organização. A Direção deve assumir uma função ativa na avaliação do desempenho, 
orientando os esforços de melhoria e fornecendo os recursos necessários para implementar, manter e melhorar continuamente os processos.

O principal fator de sucesso no processo para a melhoria é a liderança da Alta Direção. A ênfase maior dada pela ISO 9000:2000 para o envolvimento da Alta Direção é um acréscimo muito positivo às normas.

\section{$\checkmark$ Princípio 3 - Envolvimento de pessoas}

Determina que a Direção assegure que todos os colaboradores tenham "consciência" de como seu trabalho contribui para o alcance dos objetivos de qualidade da organização. Também determina que a Direção deve fornecer treinamento e assegurar que os colaboradores tenham a competência (não apenas a qualificação) necessária para desempenhar suas atividades. Ferreira (1986) define competência como "Qualidade de quem é capaz de apreciar e resolver certo assunto, fazer determinada coisa; capacidade, habilidade, aptidão, idoneidade". A competência não é responsabilidade do indivíduo, mas da Direção.

A causa raiz mais freqüente dos não-cumprimentos dos requisitos (e da insatisfação dos clientes) é a ausência de requisitos claros, ou falhas na comunicação de requisitos claros, para aqueles que operam os processos.

\section{$\checkmark$ Princípio 4 - Abordagem de processo}

Define um processo como: "uma atividade que usa recursos e os gerencia de maneira a permitir a transformação de entradas, em saídas", em cada categoria. A "abordagem de processo" reconhece que uma empresa engloba uma série de processos individuais com os resultados de um freqüentemente fornecendo entradas para o próximo processo.

Um sistema de gestão da qualidade baseado em processos promove a análise da organização através das linhas funcionais e departamentais, procurando identificar a interação entre os processos. 
O conceito, com base nos processos, afasta a ISO 9000 de suas raízes e do controle de qualidade, além de alinhá-la com o pensamento moderno de melhoria continua.

\section{$\checkmark$ Princípio 5 - Abordagem sistêmica para a gestão}

A abordagem sistêmica relacionada a Direção implica que ela deverá fornecer recursos e processos capazes de:

- Determinar quais as expectativas dos clientes;

- Traduzir essas expectativas em requisitos específicos de produtos e serviços;

- Desenvolver processos capazes e confiáveis para entregar os produtos e serviços;

- Medir a fim de conferir se os clientes estão recebendo o que foi prometido; e

- Adotar ações para melhorar continuamente os processos, com base nos dados levantados.

\section{$\checkmark$ Princípio 6-Melhoria contínua}

Determina que a organização deverá utilizar as informações provenientes do sistema de qualidade para implementar melhorias. A Norma determina especificamente que os esforços de melhoria devem incluir uma política da qualidade, objetivos da qualidade, análise das medições, ações corretivas, ações preventivas e a análise crítica pela administração de sua efetividade.

\section{$\checkmark$ Princípio 7 - Abordagem factual para tomada de decisão}

O sétimo princípio enfatiza a necessidade de levantar e analisar dados sobre os processos de trabalho. Os dados são obtidos de diversas fontes, como por exemplo, medições da satisfação dos clientes, reclamações dos clientes, garantias, devoluções, falhas em ensaios e outras medições dos processos. As decisões devem ser tomadas com 
base em fatos, ao invés de opiniões. As medições em andamento fornecem a evidência da eficácia das ações de melhoria.

\section{$\checkmark$ Princípio 8-Benefícios mútuos nas relações com os fornecedores}

Os relacionamentos da organização com seus fornecedores devem ser desenvolvidos do mesmo modo que a abordagem sistêmica e o envolvimento da Alta Direção (vide princípio \#5), ou seja, atravessando as barreiras departamentais para a melhoria da qualidade, para assegurar que o cliente receba o que foi prometido. A organização deve compartilhar informações detalhadas sobre a qualidade com seus fornecedores e deve insistir na participação dos fornecedores nas ações de melhoria. A franqueza e a confiança mútua é fundamental para que ambos prosperem com este tipo de relacionamento.

\subsubsection{A NBR ISO 9000:2000 - Fundamentos e Vocabulário}

Esta Norma descreve os fundamentos de um sistema de gestão da qualidade e estabelece a terminologia para estes sistemas.

Na tentativa de explicar os benefícios de um SGQ, é colocado que a implantação deste sistema pode ajudar as organizações a aumentar a satisfação do cliente.

Clientes exigem produtos com características que satisfaçam as suas necessidades e expectativas. Estas necessidades e expectativas são expressas nas especificações de produtos e são geralmente designadas como requisitos do cliente. Requisitos do cliente podem ser especificações contratuais ou serem determinadas pela própria organização. Em qualquer caso, será sempre o cliente que, em última análise, determinará a aceitabilidade do produto. Como as necessidades e expectativas dos clientes estão mudando, e devido às pressões competitivas e aos avanços tecnológicos, as organizações são induzidas a melhorar continuamente seus produtos e processos.

Assim colocada na NBR ISO 9000:2000, a abordagem do sistema de gestão da qualidade incentiva as organizações a analisar os requisitos do cliente, definir os 
processos que contribuem para a obtenção de um produto que é aceitável para o cliente e manter estes processos sob controle. Um sistema de gestão da qualidade pode fornecer a estrutura para a melhoria contínua com o objetivo de aumentar a probabilidade de ampliar a satisfação do cliente e de outras partes interessadas. Ele fornece confiança à organização e a seus clientes de que é capaz de fornecer produtos que atendam aos requisitos do cliente de forma consistente.

No item 2.3 da Norma é colocado que os itens para desenvolver e implementar um sistema de gestão da qualidade consistem em:

$\checkmark$ Determinar as necessidades e expectativas dos clientes;

Estabelecer uma Política da Qualidade e seus objetivos;

Determinar os principais processos internos;

Disponibilizar recursos;

Definir e aplicar métodos para medir a eficácia e eficiência dos processos;

Determinar formas para prevenir não-conformidades e eliminar as suas causas;

Buscar ferramentas para garantia da melhoria contínua do SGQ.

Para que as organizações funcionem de forma eficaz, elas têm que identificar e gerenciar processos inter-relacionados e interativos. A identificação sistemática e a gestão dos processos empregados na organização e, particularmente, as interações entre tais processos são definidas nesta Norma como "abordagem de processos".

A intenção desta Norma, como é citado em seu próprio texto, é de encorajar a adoção da abordagem de processos para a gestão das organizações.

Dentro do SGQ proposto pela nova versão da série ISO 9000:2000 a alta direção tem função primordial para a sustentação de todo o sistema. No item 2.6 da NBR ISO 9000:2000 é colocado que através de liderança e ações, a Alta Direção pode criar um 
ambiente onde as pessoas estão totalmente envolvidas e no qual o sistema de gestão da qualidade pode operar eficazmente.

Os princípios de gestão da qualidade podem ser usados pela Alta Direção como base de sua função.

Esta série da Norma traz também o valor da documentação, não simplesmente exigindo a elaboração de diversos procedimentos documentados, sendo descrito que esta documentação permite a comunicação do propósito e a consistência da ação. Seu uso contribui para atingir a conformidade com os requisitos, prover os treinamentos, assegurar a rastreabilidade e a repetibilidade, prover a evidência objetiva e por fim avaliar a eficácia e a contínua adequação do SGQ.

De acordo com esta Norma é descrito que a geração da documentação não deva ser um fim em si mesma, mas uma atividade que agregue valor.

Em se tratando do processo de avaliação do SGQ a Norma coloca que devem ser formuladas quatro questões básicas em relação a cada um dos processos que estão sendo avaliados.

$\checkmark$ O processo está identificado e apropriadamente definido?

$\checkmark$ As responsabilidades estão atribuídas?

$\checkmark$ Os procedimentos estão implementados e mantidos?

$\checkmark$ O processo é eficaz em alcançar os resultados requeridos?

Dentro do processo de avaliação do SGQ as auditorias têm um papel fundamental. Elas são usadas para determinar em que grau os requisitos do SGQ foram atendidos. As constatações da auditoria são usadas para avaliar a eficácia do SGQ e para identificar oportunidades de melhoria.

Uma das definições para um SGQ é que ele representa a parte da organização cujo enfoque é alcançar resultados em relação aos objetivos da qualidade, para satisfazer às necessidades, expectativas e requisitos das partes interessadas, conforme 
apropriado. Os objetivos da qualidade complementam outros objetivos da organização, tais como os relacionados ao crescimento, captação de recursos financeiros, lucratividade, meio ambiente, segurança e saúde ocupacional. As várias partes de um SG da organização podem ser integradas, juntamente com o SGQ, dentro de um SG único, utilizando-se elementos comuns. Isto pode facilitar o planejamento, a alocação de recursos, definição de objetivos complementares e avaliação da eficácia global da organização.

\subsubsection{A NBR ISO 9001:2000 - Requisitos}

A Norma especifica requisitos para um sistema, segundo os quais uma organização precisa:

$\checkmark$ demonstrar sua capacidade para prover consistentemente produtos que atendam aos requisitos do cliente e aos regulamentos aplicáveis, e

$\checkmark$ atingir a satisfação do cliente através da efetiva aplicação do sistema, incluindo processo para melhoria contínua e prevenção de não-conformidades.

O resultado das considerações e revisões foi a criação de um novo formato para a ISO 9001, direcionando-a a um enfoque de processo, o qual classifica as atividades de uma organização em cinco seções básicas. A Figura 10 mostra estas cinco seções.

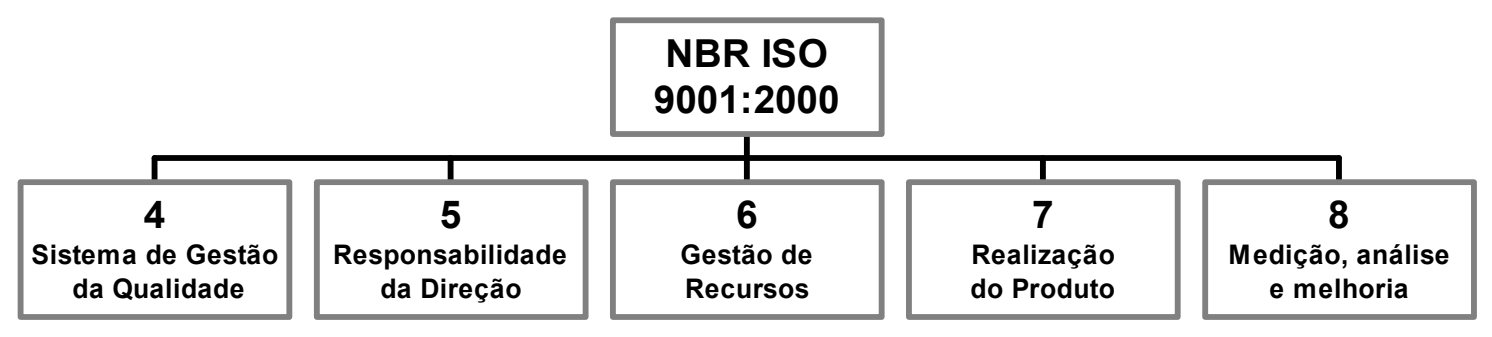

Figura 10 - Seções da NBR ISO 9001:2000

\section{Seção 4 - Sistema de Gestão da Qualidade:}

Estabelece requisitos globais para um SGQ, incluindo requisitos para documentação e registros. A documentação do SGQ deve incluir declaração da Política da Qualidade e seus objetivos, Manual da Qualidade, procedimentos documentados e 
outros julgados necessários à gestão da qualidade da organização, e os registros requeridos.

O Manual da Qualidade deve incluir detalhes e justificativas para qualquer exclusão, procedimentos documentados ou referência aos mesmos e, um item novo, uma descrição da seqüência e interação entre os processos incluídos no SGQ.

As exclusões de algum requisito somente são permitidas desde que não isentem a organização de sua responsabilidade de fornecer produtos que atendam aos requisitos do cliente e aos requisitos regulamentares aplicáveis. Estas exclusões permitidas limitam-se aos requisitos da seção 7 (Realização do Produto) e podem ser devido à natureza da organização, aos requisitos do cliente ou a requisitos regulamentares aplicáveis, devendo ser descritas e justificadas, como já foi dito, no Manual da Qualidade, a fim de garantir que os clientes não sejam induzidos a erros ou fiquem confusos sobre os objetivos do SGQ da empresa.

A norma exige também que a organização, para realizar suas atividades de produção e serviços associados, considere a disponibilidade de instruções de trabalho. As pessoas-chave da empresa deverão demonstrar ter um efetivo controle sobre os processos e sobre o SGQ como um todo.

O controle de registros agora é tratado como um dos subitens constantes desta seção (4.2.4) e não mais em um requisito à parte como na versão 94. Mudaram alguns parâmetros para controle com a finalidade de objetivar o controle dos registros da qualidade, sendo eles a identificação, armazenamento, proteção, recuperação, tempo de retenção e descarte dos registros.

\section{$\checkmark$ Seção 5 - Responsabilidade da Direção:}

A responsabilidade da direção passa a assumir uma nova dimensão, em que os membros da direção devem acompanhar desde a manutenção até a melhoria do Sistema. Esta versão foi projetada de forma a transferir a responsabilidade pelo SGQ do RD (Representante da Direção) para a Alta direção. 
Percebe-se a mudança conceitual do papel da direção em relação ao SGQ com a inclusão recorrente na introdução dos itens da expressão “A Alta Direção deve...”, o que denota o papel que a ISO espera que as gerências superiores cumpram no estabelecimento e condução do SGQ da empresa.

Isto fica bem claro logo no requisito 5.1 Comprometimento da direção, no qual está descrito que "A Alta Direção deve fornecer evidências do seu comprometimento com o desenvolvimento e com a implantação do sistema de gestão da qualidade e com a melhoria contínua de sua eficácia...". Neste ponto a Norma explicita que a Direção da empresa deve mostrar-se envolvida, através de ações concretas, com o todo o SGQ, sendo que estas ações devem ser tomadas no sentido de obter uma maior eficácia e se possível melhorar a eficiência de todo este sistema. Entende-se aqui que a eficácia e eficiência do SGQ estão ligadas com a eficácia e eficiência do negócio da empresa.

Uma das muitas novidades desta nova versão é o "foco no cliente", sobre o qual o texto da Norma diz: "A Alta Direção deve assegurar que os requisitos do cliente são determinados e atendidos com o propósito de aumentar a satisfação do cliente". Segundo Giammusso (2000), as organizações dependem de seus clientes e, portanto, devem compreender suas necessidades atuais e futuras, atender suas solicitações e esforçar-se para exceder suas expectativas.

Nesse sentido, Melhado (1994) coloca que um dos pontos mais críticos do subsetor de edificações está nos problemas de projeto, devido à incorreta identificação e interpretação dos desejos dos clientes e dos objetivos do empreendimento na elaboração do programa de necessidades.

Com relação à Política da Qualidade, que agora possui um item específico (5.3), as mudanças observadas foram a inclusão da melhoria contínua da eficácia do SGQ da empresa e a sua análise crítica periódica.

Os objetivos da qualidade nesta nova revisão não mais se limitam somente ao atendimento da Política da Qualidade; a alta direção deve assegurar que estes objetivos são estabelecidos para as funções e níveis pertinentes da organização de 
modo a demonstrar o comprometimento com a melhoria contínua e o atendimento aos requisitos do produto.

Para a análise crítica da Direção foram inseridos itens de entrada que devem incluir o desempenho atual e oportunidade de melhoria relativa a resultados de auditorias, informações de clientes, desempenho do processo e conformidade do produto, situações de ações corretivas e preventivas, ações de acompanhamento de análises anteriores e mudanças que possam afetar o SGQ. Já como saída, a Norma estabelece que estes resultados devem incluir, além de ações relativas à melhoria contínua do SGQ, a melhoria do produto relativa aos requisitos do cliente e às necessidades de recursos.

\section{$\checkmark$ Seção 6 - Gestão de Recursos}

De acordo com esta seção a organização deve determinar e prover recursos necessários para implementar, manter e melhorar continuamente o SGQ além de aumentar a satisfação dos clientes. Os requisitos referentes aos recursos humanos foram ampliados, bem como introduzidas questões como a competência da equipe, suas habilidades, experiência profissional e eficácia dos treinamentos.

Percebe-se que na versão 2000 a qualificação dos funcionários fica bem definida, sem contudo estar vinculada a procedimentos documentados, sendo aceitos experiência profissional, habilidades e outras competências dos funcionários, havendo uma maior preocupação com a efetividade dos treinamentos e da utilização das capacidades individuais da equipe na busca pela qualidade.

Com relação à infra-estrutura necessária para alcançar a conformidade com os requisitos do produto, a versão 2000 determina que ela inclua, quando aplicável, espaço de trabalho, edifícios, instalações associadas, equipamentos e serviços de apoio. Também se deve determinar e gerenciar as condições do ambiente de trabalho. 


\section{$\checkmark$ Seção 7 - Realização do produto}

Os principais requisitos dessa seção incluem os elementos a seguir enumerados, devendo o usuário da norma sempre lembrar que, conforme definido em toda a série ISO 9000, o termo "produto" pode também significar "serviço":

- Requisitos para planejamento e desenvolvimento dos processos necessários para a realização do produto;

- Requisitos para análise crítica de contrato e comunicação com o cliente, nos processos relacionados ao cliente;

- Requisitos para projeto e desenvolvimento do produto, incluindo o controle de alterações desses elementos;

○ Requisitos para aquisição;

- Requisitos para a produção e fornecimento de serviços (controle de processos, incluindo processos especiais, requisitos para identificação e rastreabilidade; requisitos para controle da propriedade do cliente e para preservação do produto);

○ Controle de dispositivos de monitoramento e medição.

Esta é a seção da versão 2000 da ISO 9001 que instrui a organização como efetuar o planejamento dos seus processos.

Qualquer processo é uma atividade ou uma seqüência de atividades correlacionadas que têm entradas e saídas. São de extrema importância a definição das saídas requeridas dos processos e a identificação das entradas necessárias e das atividades requeridas para sua realização eficaz e eficiente.

A inter-relação dos processos pode ser complexa, resultando em redes de processos. Para assegurar a operação eficaz e eficiente da organização, é necessário reconhecer que a saída de um processo pode se tornar entrada para um outro. 
O entendimento de que um processo pode ser representado como uma sucessão de atividades ajuda a direção a definir as entradas do processo. Uma vez que as entradas tenham sido definidas, podem ser determinadas as atividades necessárias, bem como as ações e os recursos requeridos para o processo, com a finalidade de se obterem as saídas desejadas.

É a única seção em que a organização tem permissão de excluir algum requisito, desde que não afetem a capacidade ou responsabilidade da organização de fornecer produtos que atendam aos requisitos dos clientes e do produto, e estas exclusões devem ser muito bem explicadas no Manual da Qualidade.

Esta seção está estruturada seguindo o conceito de processo produtivo, independente do tipo de produto entregue pela organização. Partindo do planejamento, seguindo pelos processos relacionados ao cliente, processos de projeto e desenvolvimento do produto, aquisição, produção e finalmente medição e acompanhamento.

Percebe-se que esta nova estruturação reforça o conceito de gestão orientada para processos, pois os requisitos devem ser cumpridos observando-se a sua interligação e não separadamente.

De acordo com Alves (2001), no caso da construção civil, isto facilita a compreensão da norma quanto à sua utilização, pois se utiliza a mesma estrutura comum ao setor, partindo-se dos requisitos do cliente e do projeto, passando pelo planejamento, execução e controle da obra.

\section{$\checkmark$ Seção 8 - Medição, Análise e Melhoria}

Nessa seção, os requisitos para auditoria interna foram ampliados, incluindo agora também a auditoria do SGQ conforme disposições estabelecidas pela própria organização. Outros elementos dessa seção abrangem:

- Planejamento e implementação de processos de monitoramento, medição, análise e melhoria contínua;

- Monitoramento de informações relacionadas ao cliente, como uma das medidas de desempenho do SGQ; 
○ Monitoramento e medição de processos;

○ Monitoramento e medição do produto;

○ Controle de produto não-conforme;

○ Análise de dados;

○ Melhoria contínua da eficácia do SGQ;

○ Ação corretiva;

○ Ação preventiva.

A nova revisão exige da organização não só a análise dos resultados das inspeções dos processos internos e de seus produtos, ela também exige a análise do desempenho do próprio SGQ e de como este atende as expectativas dos clientes e cumprimento da política da qualidade.

De acordo com a NBR ISO 9004:2000, medições são importantes para se tomar decisões com base em fatos. Convém que a alta direção assegure medições eficazes e eficientes, coletando e validando os dados para assegurar o desempenho da organização e a satisfação das partes interessadas. Convém que isso inclua a análise crítica da validade e da finalidade das medições e o uso pretendido dos dados para assegurar valor agregado à organização. 


\section{MudanÇAS No SGQ COM A VERSÃo 2000 da ISO 9000}

Nos capítulos anteriores foram analisados alguns itens da série ISO 9000 versão 2000. Já neste capítulo serão abordadas as principais mudanças introduzidas com esta revisão, algumas delas são apresentadas abaixo:

$\checkmark$ A Série ISO 9000: Existência de uma única norma para certificação e cancelamento das ISO 9001:1994, 9002:1994 e 9003:1994;

$\checkmark$ Terminologia: Substituição da terminologia "subcontratado $\rightarrow$ fornecedor cliente" por "fornecedor $\rightarrow$ organização $\rightarrow$ cliente";

$\checkmark$ Procedimentos obrigatoriamente documentados: A revisão 2000 da norma agora exige somente seis procedimentos, devendo a empresa decidir sobre qual outra documentação ela necessitará para controlar suas operações e processos;

$\checkmark$ Abordagem por processos: Enfoque baseado no modelo de processo, a versão 1994 da norma dividia os requisitos para um sistema da qualidade em 20 categorias, promovendo a determinação da responsabilidade de seu cumprimento aos departamentos funcionais tradicionais (Pesquisa e desenvolvimento, engenharia, compras, inspeção, ensaios, logística, etc.). Há um requisito específico para a organização descrever seus processos e como eles interagem. A Figura 11 mostra a visão da União Certificadora (UCIEE) em relação à interação dos processos internos da empresa e seu SGQ.

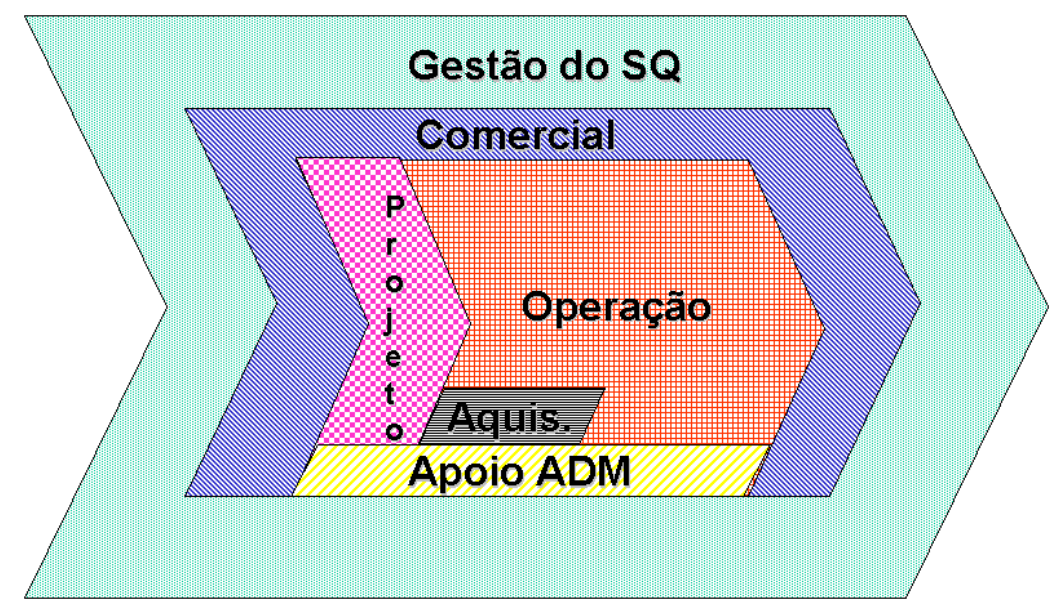

Figura 11 - Modelo de interação dos processos internos com o SGQ (Fonte: UCIEE,2003) 
$\checkmark$ Melhoria Contínua: Exigência formal de um processo de melhoria contínua e de monitoramento da satisfação do cliente, a versão de 1994 obrigava a organização a demonstrar que os processos de trabalho eram definidos, que os operadores cumpriam essas definições e que os produtos não-conformes eram identificados e segregados. Chama a atenção que a versão de 1994 não exigia que a organização adotasse qualquer ação para melhorar a qualidade de seus produtos e serviços.

$\checkmark$ Comunicação interna: Há agora uma seção que estabelece que uma organização deve ter um processo de comunicação interna que forneça informações sobre o SGQ e sua eficácia, As versões da norma de 1987 e 1994 podiam ser atendidas com base nas funções tradicionais (e independentes) de qualidade. Planejamento da qualidade, gestão da qualidade dos suprimentos, inspeção e ensaios, ações corretivas e auditorias da qualidade podiam ser administradas como extensões das atividades produtivas, ao invés de integrá-los nos processos de forma a acrescentar valor aos resultados da organização.

$\checkmark$ Competência: A questão foi também introduzida e deverá ser considerada na avaliação e no treinamento dos recursos humanos da organização. Na versão 1994 a exigência de treinamento é descrita no item 4.18, segundo o qual a organização deve estabelecer e manter procedimentos para identificar as necessidades de treinamento e providenciá-lo para o pessoal que executa as atividades que influem na qualidade.

Representante da Direção: A versão 1994 apenas estabelecia exigências de indicar um "representante da administração" e de ter uma política da qualidade. Hoje, o papel da liderança é muito mais abrangente. Na versão anterior, a responsabilidade da direção (ou da Administração segundo ISO 9001 versão 1994), era estabelecida principalmente pelo estabelecimento da política e dos objetivos da qualidade, comunicando-os ao restante da organização. A questão da responsabilidade da direção era passada ao RA (Representante da Administração), que deveria estabelecer a documentação, enquanto os principais membros da direção apenas participavam de reuniões semestrais para a análise crítica do SGQ da empresa. 
Foco no cliente: A versão 1994 focalizava os padrões internos da organização, ao invés das expectativas do cliente. Se os padrões da empresa não coincidiam com as necessidades dos clientes eles ficavam desapontados. A norma de 1994 não exigia qualquer medição da satisfação dos clientes.

$\checkmark$ Abordagem sistêmica: A versão de 1994 determinava um conjunto de práticas de qualidade que, até determinado grau, levava à implementação de partes do sistema, mas sem a integridade de uma "abordagem sistêmica". Isso resultava em que cada silo da organização fizesse a tarefa designada. Assim, Marketing identificava o que os clientes queriam, Pesquisa e Desenvolvimento traduziam isso em especificações, Engenharia projetava, Suprimentos comprava as peças, Produção produzia, Qualidade media os defeitos, Logística entregava e Serviços aos Clientes pediam desculpas pelos resultados. A abordagem sistêmica elimina as barreiras entre as funções (inclusive entre a organização e seus fornecedores e clientes).

$\checkmark$ Política da Qualidade: Na versão de 1994 a Política da Qualidade poderia ser estabelecida e não passar por nenhuma melhoria ou alteração, o que não acontece com a versão 2000, que visa justamente a sua análise e atualização para a melhoria contínua do sistema.

$\checkmark$ Análise Crítica: Na versão anterior este item ficava restrito à necessidade da realização de análises críticas periódicas, suficientes para assegurar a adequação e eficácia no atendimento aos requisitos na Norma, Política da Qualidade e de seus objetivos, não havendo preocupação com a real eficácia, melhoria contínua e retroalimentação de informações do cliente.

$\checkmark$ Ambiente de trabalho: Na versão 1994, as condições de ambiente de trabalho e infra-estrutura necessários ao bom andamento das atividades de produção encontram-se no item 4.9 b. Em ambas as versões fica a cargo da empresa a determinação de que condições adequadas de trabalho são essas e que equipamentos e serviços de suporte podem ser necessários. 
Crosby (2003) resume os benefícios potenciais de utilizar as normas ISO 9000:2000 para ajudar a impulsionar as iniciativas de melhoria da qualidade. Ele coloca que a ISO 9000:2000 tem o potencial de tornar-se muito útil, à medida que aqueles que a utilizam recebam a educação necessária e sejam bem orientados através dos seus princípios e requisitos.

Este mesmo autor complementa que o mundo empresarial tem a angustiante necessidade de tornar-se mais confiável. Em todos os lugares, os executivos falam do seu desejo de que suas empresas tenham a reputação de serem confiáveis. As especificações da ISO 9000:2000 poderão ajudar bastante, mas necessitam ser corretamente posicionadas e precisam ser sustentadas pela educação. Necessitam ser parte de uma abordagem ampla e abrangente, visando ajudar as organizações a tornarem-se confiáveis. A ISO 9000:2000 não pode sustentar tudo isso, de forma isolada.

\subsection{Estrutura e exigências da Norma versão 2000}

As 20 cláusulas da versão de 1994 foram reduzidas para apenas 8 cláusulas. Segundo Mott (2003) a versão de 1994 era fundamentada em um modelo de manufatura e incluía requisitos específicos para projetos, de produção e gestão de fornecedores. Isso resultou em uma abordagem do tipo "caixa preta", a partir da qual algumas consultorias de ISO escreviam procedimentos genéricos de qualidade para seus clientes. Como conseqüência, em algumas empresas, as práticas gerenciais reais divergiam consideravelmente das práticas documentadas para a obtenção do certificado.

Com a abordagem por processos as organizações podem eliminar muito da complicada documentação de um SGQ. A Norma ISO 9001:2000 dá a oportunidade de se analisar por completo o sistema gerencial da empresa, alinhando-se o mais próximo possível com a prática gerencial do dia-a-dia.

Este enfoque de processo unificado, classifica as atividades da organização em cinco cláusulas básica, como detalhado no capítulo 2. A Tabela 3 trás resumidamente a descrição dos requisitos exigidos por estas cláusulas. 
Tabela 3: Descrição dos requisitos da NBR ISO 9001:2000

\begin{tabular}{|c|c|}
\hline Seção & Descrição \\
\hline $\begin{array}{l}4 \text { - Sistema de } \\
\text { Gestão da Qualidade }\end{array}$ & $\begin{array}{l}\checkmark \text { Estabelece requisitos globais para um SGQ, incluindo } \\
\text { requisitos para documentação e registros; } \\
\checkmark \text { Define condições para documentar a Política, os } \\
\text { Objetivos e o Manual da Qualidade. }\end{array}$ \\
\hline $\begin{array}{l}5 \text { - Responsabilidade } \\
\text { da Direção }\end{array}$ & $\begin{array}{l}\checkmark \text { Estabelece responsabilidades da Alta Direção em relação } \\
\text { ao SGQ, incluindo seu comprometimento, foco no } \\
\text { cliente, planejamento das atividades do SGQ e } \\
\text { comunicação interna; } \\
\checkmark \text { É da responsabilidade da Alta Direção designar um } \\
\text { membro da organização para ser seu Representante para } \\
\text { assuntos ligados ao SGQ; } \\
\checkmark \text { Conduzir análises críticas periódicas do SGQ, } \\
\text { demonstrando que são tomadas ações relativas às } \\
\text { atividades de melhoria do Sistema da empresa. }\end{array}$ \\
\hline $\begin{array}{l}\text { 6-Gestão de } \\
\text { Recursos }\end{array}$ & $\begin{array}{l}\checkmark \text { Estabelece requisitos para o fornecimento de recursos } \\
\text { para o SGQ, incluindo requisitos para treinamento; } \\
\checkmark \text { Determina que as empresas executem suas atividades } \\
\text { com pessoal competente, com base em ações de } \\
\text { educação, treinamento, habilidades e experiências } \\
\text { apropriadas; } \\
\checkmark \text { Provenha a infra-estrutura necessária para a } \\
\text { conformidade com os requisitos do produto; } \\
\checkmark \text { Gerencie fatores de ambiente de trabalho. }\end{array}$ \\
\hline $\begin{array}{l}7 \text { - Realização do } \\
\text { Produto }\end{array}$ & $\begin{array}{l}\checkmark \text { Estabelece requisitos para a realização de produtos e } \\
\text { serviços, incluindo planejamento, análise de contrato, } \\
\text { projeto, aquisição, controle de processos de produção, } \\
\text { identificação e rastreabilidade, controle da propriedade } \\
\text { do cliente, preservação do produto e calibração de } \\
\text { equipamentos. }\end{array}$ \\
\hline $\begin{array}{l}8 \text { - Medição, Análise } \\
\text { e Melhoria }\end{array}$ & $\begin{array}{ll}\checkmark & \text { Estabelece requisitos para medição, incluindo satisfação } \\
& \text { do cliente, análise de dados e melhoria contínua; } \\
\checkmark & \text { Auditorias Internas; } \\
\checkmark & \text { Monitoramento dos processos e produtos; } \\
\checkmark & \text { Controle do produto não conforme; } \\
\checkmark & \text { Ações Corretivas e Preventivas. }\end{array}$ \\
\hline
\end{tabular}


A ISO 9001:2000 identifica seis requisitos específicos de procedimentos obrigatoriamente documentados (em oposição aos pelo menos 17 da versão de 1994). Todos eles estão relacionados a itens referentes aos sistemas de apoio à garantia da qualidade e não à realização do produto e/ou serviço.

Especificamente, são requeridos procedimentos obrigatoriamente documentados para:

\section{$\checkmark$ Controle de Documentos;}

$\checkmark$ Controle de Registros;

\section{$\checkmark$ Auditoria Interna;}

\section{$\checkmark$ Controle de Produto Não-Conforme;}

\section{Ação Corretiva e;}

\section{Ação Preventiva.}

É possível integrar os procedimentos de 'Controle de Produto Não-conforme', 'Ação Corretiva' e 'Ação Preventiva' em um único procedimento documentado. $\mathrm{Na}$ verdade, também é possível integrar os procedimentos de 'Controle de Documentos' e 'Controle de Registros'. Se isso for feito, somente serão necessários três procedimentos documentados.

A ISO 9001:2000 também requer que sejam incluídos no Sistema de Gestão da Qualidade “documentos necessários à organização para assegurar o planejamento, a operação e o controle eficazes de seus processos". O que a norma espera desse segundo tipo de 'documentação' é tanto quanto vago.Você tem uma liberdade considerável para decidir como apresentar essa 'documentação', como denominá-la e qual o nível de detalhamento que ela terá.

Entretanto, os documentos necessários para suas operações são um requisito claro e devem ser adequados à sua empresa. Eles têm a finalidade de descrever seus processos e sua operação e controles eficazes.

Em outras palavras, é preciso descrever os processos que fazem parte de seu SGQ. Também se pode optar por ter procedimentos documentados detalhados para tais processos ou alguma alternativa não especificada. De maneira muito sensata, a norma diz que a abrangência da documentação do sistema de gestão da qualidade varia de empresa para empresa (vide nota 2 da seção 4.2 da ISO 9001). 
Alguns dos fatores são o porte da organização, seu tipo, complexidade e interação, bem como a competência de seu pessoal.

Os itens da ISO 9001 que sugerem ou requerem esse segundo tipo de documentação (e os números das seções) são:

$\checkmark$ Comprometimento da direção (5.1) - utilizando a política da qualidade (5.3), os objetivos da qualidade (5.4.1) e através de ações;

$\checkmark$ Responsabilidade e autoridade (5.5.1) - precisam ser definidas e comunicadas e as responsabilidades designadas;

$\checkmark$ Planejamento dos processos de realização (7.1 b) - a necessidade de estabelecer os processos, documentos e fornecer recursos;

$\checkmark$ Análise crítica dos requisitos relacionados ao produto (7.2.2) - esse tipo de documento era conhecido como ‘análise crítica de contrato’ na ISO 9001:1994;

Disponibilidade de instruções de trabalho (7.5.1b) - quando necessário.

Este segundo tipo de documentos é muito mais flexível. Será possível utilizar a grande variedade de opções desse segundo tipo de documentos adequando-os à abordagem de competências.

Esta versão exige, além da implantação de sistemas de qualidade, a melhoria continua dos processos de trabalho. Mott (2003) coloca que isso estimula os trabalhadores a entender melhor os requisitos dos clientes, para fornecer-lhes o que desejam. Tendo em vista que as novas normas contêm menos preceitos, existirá uma maior probabilidade de que as empresas documentem suas práticas reais em vez de, simplesmente, reescrever os requisitos da norma. 


\subsection{As mudanças e suas conseqüências.}

Embora a linguagem da versão 2000 ainda tenda a alinhar-se mais com indústrias de manufatura, tornou-se mais fácil de ser aplicada em organizações de serviços.

Pode-se observar que as Normas da Série ISO 9000:2000 mudaram conceitualmente, absorvendo o princípio de retroalimentação do ciclo PDCA, preocupando-se com o sistema de gerenciamento e melhoria da empresa como um todo e estimulando um sistema de comunicação e retroalimentação com o cliente. A empresa deve ser gerenciada por processos, identificando aqueles que são críticos para a realização do produto. A Figura 12 mostra a interpretação adotada pela UCIEE em relação a este novo conceito da norma.

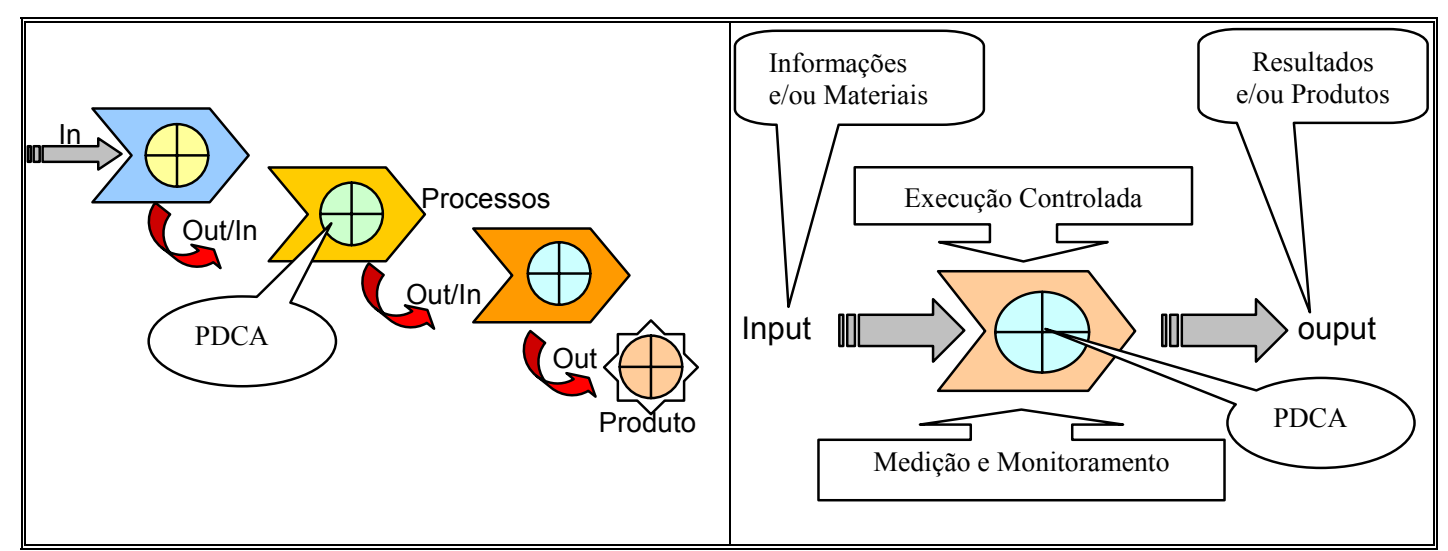

Figura 12 - Interpretação do conceito de PDCA da Série NBR ISO 9000:2000 (Fonte: UCIEE,2003).

Este sistema de comunicação deve ser pró-ativo e planejado, enfatizando-se a necessidade da prevenção das não-conformidades, exigindo-se que a medição dos processos, a coleta e análise de dados se dêem no sentido da busca de melhoria contínua e não para a correção de erros.

A versão 2000 deu enfoque ao estabelecimento e implementação de documentação necessária para a comprovação da capacidade da empresa em atender aos requisitos do cliente. A intenção é a de possibilitar a efetividade e a melhoria contínua do SGQ, tornando a empresa competitiva no mercado, diferente da versão de 1994 que apenas estabelecia 20 critérios a serem atendidos, sem a correlação entre estes e sem a necessidade de garantia de satisfação do cliente e melhoria contínua. 
Ficam claros os três principais enfoques da versão 2000: a melhoria contínua; a avaliação da satisfação do cliente; e os indicadores de desempenho.

A partir daqui serão abordados os destaque em algumas das seções da versão 2000 da série NBR ISO 9001:2000.

O ponto de destaque da seção "Introdução" da ISO 9001:2000 é, sem dúvida alguma, o modelo de processo em que agora deve se basear o Sistema de Gestão da Qualidade de uma organização. Como conseqüência, foi eliminada a estrutura de "20 elementos" da versão de 1994 e o seu conteúdo foi distribuído por toda a nova norma, tendo sido o texto consideravelmente modificado, com o propósito de apresentar os requisitos de maneira mais concisa e clara, sem contudo alterar de forma significativa o seu intento.

Já no título da nova versão, verifica-se a extinção do termo "garantia da qualidade", decorrente do fato de que esta versão vai além da garantia da qualidade do produto, visando principalmente a satisfação do cliente. Inclusive este termo aparece cerca de trinta vezes na versão 2000, enquanto que na versão 1994 só aparece quatro ou cinco vezes, comenta Alves (2001).

Na seção “Objetivo" da versão 2000, a maior mudança ocorreu com a introdução do conceito de "direcionar a satisfação do cliente por meio da efetiva aplicação do sistema, incluindo processos para a melhoria contínua e para a prevenção de nãoconformidades". Esse é, certamente, um acréscimo de grande importância, particularmente em função da necessidade explícita que uma empresa terá na busca da melhoria contínua da satisfação de seus clientes.

De acordo com a NBR ISO 9001:1994, seus objetivos seriam especificar requisitos de sistema da qualidade para uso onde há necessidade de demonstrar a capacidade do fornecedor para projetar e fornecer produtos conformes; e os requisitos especificados destinam-se primordialmente à obtenção da satisfação do cliente pela prevenção de não-conformidades em todos os estágios, desde o projeto até os serviços associados.

Já a NBR ISO 9001:2000 apresenta como objetivo a especificação de requisitos para um sistema de gestão da qualidade, quando uma organização necessita demonstrar 
sua capacidade para fornecer de forma coerente produtos que atendam aos requisitos do cliente e requisitos regulamentares aplicáveis; e pretende aumentar a satisfação do cliente por meio da efetiva aplicação do sistema, incluindo processos para melhoria contínua do sistema e a garantia da conformidade com os requisitos do cliente e requisitos regulamentares aplicáveis.

Em ambas as versões, nota-se que no primeiro momento os requisitos são para garantir que a organização forneça produtos ou serviços que atendam às especificações do cliente; porém, a grande diferença é que o foco da versão 1994 está na padronização dos processos e na versão 2000 há uma preocupação com a melhoria contínua e o aumento da satisfação do cliente.

A nova norma, como já foi dito, cancela a ISO 9001:1994, a ISO 9002:1994 e a ISO 9003:1994. Na seção 1.2 (Exclusões Permitidas), a versão 2000 dá a necessária flexibilidade para cobrir as diferenças existentes entre as três normas citadas. Tais exclusões, entretanto, estão restritas somente aos requisitos contidos na seção 7 (Realização do Produto) da ISO 9001:2000. As organizações que têm adotado a ISO 9002:1994 (que exclui o requisito "projeto e desenvolvimento") devem agora se enquadrar e acomodar seus requisitos dentro dessa abordagem de "exclusões permitidas". As empresas que estiverem em conformidade com a versão 2000 serão todas certificadas apenas pela ISO 9001 e, se forem consentidas exclusões, estas deverão ser parte integrante do critério de auditoria do Organismo Certificador e estar explicitadas no respectivo certificado.

A Política da Qualidade agora também será avaliada periodicamente para atestar a sua adequação, bem como para que hajam alterações no sentido da melhoria contínua.

A Análise Crítica pela Direção (ACD) recebeu novos itens de entradas e saídas, onde são analisados o desempenho atual e as oportunidades de melhoria do SGQ, sendo analisados inclusive requisitos explícitos e implícitos do cliente e disponibilidade de recursos materiais, humanos e financeiros. 
Foi incluído o requisito de comunicação interna como forma de criar uma atmosfera de cooperação, engajamento e co-participação de toda a equipe no andamento do SGQ, não se limitando ao representante da direção e níveis gerenciais.

Os requisitos para a provisão de recursos foram ampliados, principalmente no que diz respeito aos recursos humanos, com a introdução da análise de competências, habilidades e experiência profissional da equipe, bem como a análise da efetividade dos treinamentos realizados.

Na seção que traz a "Realização do Produto" a norma foi organizada com o conceito de processo produtivo, independentemente do tipo de produto entregue pela organização. Percebe-se que esta nova estruturação reforça o conceito de gestão orientada para processos, pois os requisitos devem ser cumpridos observando-se a sua interação e não separadamente.

Para a Construção Civil, isto facilita a compreensão da norma quanto à sua utilização, pois se utiliza a mesma estrutura comum ao setor, partindo-se dos requisitos do cliente e do projeto, passando pelo planejamento, execução e controle de obra.

Na subseção de "Planejamento da Realização do Produto" a norma estabelece que a organização deve planejar a realização de seus produtos, determinando, quando apropriado, os objetivos da qualidade e requisitos do produto.

Isto significa que, no caso da Construção Civil, no Plano da Qualidade da obra devem estar descritos os objetivos da qualidade específicos para a obra em questão, os requisitos do produto como especificações, projetos, catálogos informações dos clientes e outras, bem como a descrição e metodologia das verificações a serem realizadas na obra como forma de avaliar a conformidade com os requisitos estabelecidos.

A principal mudança introduzida na subseção 7.2 da ISO 9001 (Processos Relacionados ao Cliente) diz respeito às atividades que, na versão 1994, estavam apenas implícitas na norma como, por exemplo, a necessidade de serem considerados os requisitos legais e incluídas as expectativas do cliente. 
Isto afeta profundamente a Construção Civil, pois a comunicação com o cliente deverá ser constante a fim de reduzir suas dúvidas, realizar alterações e esclarecer ambigüidades das especificações e projetos. Maior dificuldade será encontrada no atendimento de requisitos subjetivos por excelência como status, vista, conforto entre outros tão comuns a setor.

Melhado (1994) ressaltou a importância da identificação das necessidades dos clientes através do programa de necessidades, indicando alguns dos desafios do setor da Construção Civil na elaboração dos mesmos. Aqueles citados pelo autor são a falha de especificação das características do produto por parte do empreendedor; a fixação de prazos curtos para a elaboração dos projetos; a falta de requisitos técnicos de orientação do arquiteto, quanto à escolha de métodos construtivos e especificações do edifício; a elaboração do projeto de forma compartilhada; e a dificuldade de comunicação entre projetistas e consumidores.

Na edição 2000, a subseção 7.3 (Projeto e/ou Desenvolvimento), como o próprio título sugere, agora inclui, além do projeto, requisitos relacionados a todo o desenvolvimento do produto. A subseção 7.3.1 engloba o conteúdo de 4.4.1, 4.4.2 e 4.4.3 da versão 1994.

As entradas relativas a requisitos do produto devem ser determinadas e registradas. A versão 2000 estabelece claramente que devem ser incluídos aí requisitos de funcionamento e de desempenho dos projetos, inclusive com a utilização de informações de projetos semelhantes anteriores. Devem ser incluídos também requisitos regulamentares e outros julgados essenciais ao projeto.

Há na NBR ISO 9001:2000 uma nota que estabelece que os requisitos do projeto deverão estar completos, sem ambigüidades e não conflitantes entre si. Nota-se que esta é preocupação clara em relação à informação contida nos projetos para torna-los eficazes na satisfação de seus requisitos.

Esta preocupação é bastante pertinente, uma vez que em muitos casos a dificuldade no atendimento às necessidades do cliente deve-se às ambigüidades existentes nos projetos. Para a Construção Civil, isto significará a necessidade de uma maior 
atenção aos projetos, mesmo para as empresas construtoras, pois a inexistência, inadequação ou ambigüidade de suas informações serão de responsabilidade de quem executa os serviços.

Alves (2001) coloca que apesar deste item estar mais conciso na versão 2000, a exigência quanto à eficácia dos projetos é maior. As empresas construtoras deverão encontrar maneiras de diminuir as dúvidas e incompatibilidade dos projetos em tempo hábil, a fim de não comprometer a satisfação do cliente na inspeção e recebimento final do edifício.

Ainda com relação ao requisito de projeto a NBR ISO 9001:2000 estabelece que as análises críticas da organização deverão avaliar a capacidade dos resultados do projeto atenderem aos requisitos e identificar qualquer problema. No caso da Construção Civil, os projetos passarão a ser analisados periodicamente e não mais apenas no seu recebimento na obra. A equipe técnica da obra deverá preocupar-se em realizar constantemente análises críticas e verificação de compatibilidade dos projetos, estreitando a sua relação com os diversos projetistas envolvidos a fim de verificar a sua adequação.

Há um novo conceito na ISO 9001:2000: o de que a "Propriedade do Cliente" (ou "Controle de Produto Fornecido pelo Cliente", da edição 1994) pode incluir a propriedade intelectual como, por exemplo, a informação fornecida em confiança. As empresas de serviços são provavelmente as que mais poderão ser afetadas por esse novo conceito.

Para as empresas construtoras que permitem modificação propostas por clientes, este requisito deve ser aplicado, pois um projeto arquitetônico proposto por um cliente deve ser considerado como de sua propriedade.

Na subseção “Aquisição” (7.4), a NBR ISO 9001:2000, estabelece que o processo de aquisição da organização deverá assegurar que os produtos adquiridos estão de acordo com os requisitos especificados, sendo que o tipo e a extensão do controle aplicado ao fornecedor e ao produto adquirido deverão depender do efeito deste produto na realização do produto final. 
$\mathrm{Na}$ versão de 94 (item 4.6.2), a norma estabelecia praticamente a mesma coisa, porém com uma redação que pode dar margem a distorções. A versão atual dá mais flexibilidade em relação aos requisitos necessários à aquisição dos produtos, tornando-a mais facilmente aplicável aos diversos setores.

Para a Construção Civil, a inclusão do item que estabelece que na avaliação dos fornecedores e dos produtos deve-se levar em conta o seu efeito no produto final, significa que os itens críticos da obra devem ser avaliados mais minuciosamente como no caso do concreto estrutural, instalações e outros estabelecidos pela empresa construtora no plano da qualidade da obra.

Ainda nesta subseção, é estabelecido que as informações de aquisição devem descrever o produto a ser adquirido e incluir, onde apropriado, requisitos para a aprovação deste produto. Esta é outra alteração significativa para a Construção Civil, pois se por um lado, a versão 2000 é mais abrangente e flexível neste requisito, por outro exige que sejam incluídos os requisitos para a aprovação, definindo os critérios de aceitação.

A versão 2000 da NBR ISO 9001 estabelece que para a "Produção e Fornecimento de Serviço" (7.5) devem ser definidos, quando aplicável, a disponibilidade de informações que descrevam as características do produto, a disponibilidade de instruções de trabalho, o uso de equipamentos adequados, a disponibilidade e a implementação de dispositivos de monitoramento e medição, além da determinação de critérios de liberação e entrega e atividades de pós-entrega.

A subseção 7.5.2 (Validação de Processos) cobre os chamados "Processos Especiais" da 4.9 da versão 1994. Ela continua abrangendo os mesmos conceitos e ainda requer o mesmo grau de controle e verificação. A edição 2000 utiliza o termo "verificação" em vez de "qualificação", partindo da premissa de que o conceito de verificação é mais amplo e inclui a qualificação.

Muitas vezes na Construção Civil, alguns dos processos de produção só podem ser validados após o uso das edificações. Tem-se no entanto os processos de produção de materiais a serem incorporados à edificação que permitem a sua validação antes de 
serem aplicados. É o caso, por exemplo, da produção de argamassa e concreto in loco que devem ter seus "traços" ensaiados para verificar se atendem às especificações de projeto.

A versão 2000 também removeu a ambigüidade que havia na norma de 1994: se os requisitos de manuseio, armazenamento, embalagem e preservação deveriam ser aplicados somente ao produto final ou a todos os estágios do processamento interno. Agora, está bem claro que eles se aplicam a todos os estágios do referido processamento, bem como à entrega final do produto, independentemente de tais requisitos estarem ou não contratualmente especificados.

Isto na Construção Civil não é uma grande alteração, pois os materiais e serviços executados ao longo da obra são na sua grande maioria protegidos a fim de se evitar a sua degradação antes da entrega da mesma, com por exemplo a proteção da cabine do elevador definitivo durante a fase final da obra, permitindo com isso o uso pelos operários sem causar danos antes da entrega.

O item correspondente ao antigo 4.11 (Controle de Equipamentos de Inspeção, Medição e Ensaios), atualmente 7.6 (Controle de Dispositivo de Medição e Monitoramento), basicamente não foi alterado. O que se percebe é que houve uma síntese, sendo a versão 2000 menos descritiva.

A seção 8 (Medição, Análise e Melhoria) foi a mais inovadora, declara Alves (2001), pois fecha o processo iniciado na responsabilidade da direção e, através do item de melhorias, fecha o ciclo PDCA.

Para a Construção Civil, especificamente neste item, é mais facilmente assimilável, adaptando-se melhor às empresas de serviços, pois possibilita que a organização estabeleça quais são os indicadores que melhor se aplicam ao seu ramo de negócios e à sua política e objetivos da qualidade já estabelecidos.

Já as menções à melhoria contínua e à eficácia do SGQ são completamente novas. Isto indica claramente a mudança conceitual da versão 2000, que se preocupa com um sistema de gestão baseada em fatos consistente, tanto na busca pela melhoria da eficácia do Sistema quanto para um melhor desempenho da empresa como um todo. 
As empresas deverão ter atenção na definição de seus indicadores, buscando utilizar aqueles que tenham aplicação prática, que sejam facilmente mensuráveis e que sejam essenciais ao bom desempenho de seus produtos/serviços, SGQ e da própria empresa.

A subseção 8.2.1, trata da Medição da Satisfação e/ou Insatisfação do Cliente. Cada empresa deverá definir como pretende fazer isso, que abordagens adotará, e como os dados serão registrados, analisados e utilizados.

Segundo Jobim e Formoso (1998) apud Alves (2001), o foco no cliente deve iniciar muito antes das etapas de projeto e produção. A primeira etapa do processo de comunicação com o cliente é a própria identificação das necessidades do mesmo. A avaliação do cliente e a avaliação de sua satisfação devem servir de fonte de dados para a retroalimentação das etapas de um empreendimento como um todo, como por exemplo marketing, planejamento, projeto, suprimento, gerenciamento, execução e manutenção de obras.

Este monitoramento da satisfação dos clientes talvez seja um dos requisitos que, conceitualmente, trazem mais dificuldades de aplicação na Construção Civil, pois implicam num canal de comunicação e avaliação pós-ocupação para todos os empreendimentos, o que não ocorre usualmente.

No caso de clientes públicos esta situação ainda se torna mais delicada, pois os contratantes não são normalmente os usuários finais. Muitas vezes a insatisfação destes usuários finais com relação ao empreendimento ou à Construtora são na realidade reflexo das definições do órgão contratante, como por exemplo insatisfação devido a uma concepção equivocada de projeto, que normalmente não é de responsabilidade da construtora.

A subseção 8.4 (“Análise de Dados”) é outro requisito novo que foi introduzido. Os resultados dessa análise deverão se relacionar com a subseção 8.5 ("Melhoria”) e, possivelmente, com a “Análise Crítica pela Administração” (subseção 5.6). 
Na versão de 94, o único item que mencionava de avaliação com base em dados era o referente às técnicas estatísticas. Porém nela a organização deveria apenas identificar a necessidade da utilização destas técnicas para implementá-las e controla-las.

A análise de dados deverá ser objetiva, baseada em dados reais e visar uma efetiva melhoria do SGQ, tendo seus resultados analisados periodicamente para manter a sua eficácia. Com isso o SGQ obrigatoriamente se tornará mais dinâmico.

Para facilitar a compreensão e tornar mais claras as principais mudanças, a Tabela 4 traz uma síntese destas mudanças.

Tabela 4: Síntese das principais alterações na versão 2000 da NBR ISO 9001.

\begin{tabular}{|c|c|}
\hline Era na versão 94 & Como é hoje... \\
\hline $\begin{array}{l}\checkmark \text { O SGQ era baseado } \\
\text { fortemente em seus } \\
\text { procedimentos documentados. }\end{array}$ & $\begin{array}{l}\checkmark \text { O SGQ é baseado em seus processos. (item } \\
0.2 \text { ) }\end{array}$ \\
\hline $\begin{array}{l}\checkmark \text { O desenvolvimento de } \\
\text { procedimentos documentados } \\
\text { era requerido de forma } \\
\text { extensiva. }\end{array}$ & $\begin{array}{l}\checkmark \text { Procedimentos documentados são exigidos } \\
\text { em apenas seis requisitos. Em todos os } \\
\text { demais casos a necessidade de documentar } \\
\text { um determinado procedimento é decidida } \\
\text { pela própria empresa (itens } 4.1 \text {.c e } 4.2 .1 \text {.d) }\end{array}$ \\
\hline $\begin{array}{l}\checkmark \text { O objetivo maior do SGQ era } \\
\text { assegurar a repetitividade e a } \\
\text { previsibilidade. }\end{array}$ & $\begin{array}{l}\checkmark \text { Repetitividade e previsibilidade são } \\
\text { necessárias, mas o principal objetivo do } \\
\text { SGQ é a satisfação dos clientes. (itens } 0.2 \mathrm{e} \\
0.3 \text { ) }\end{array}$ \\
\hline $\begin{array}{l}\checkmark \text { A estrutura da Norma permitia } \\
\text { análises e auditorias de } \\
\text { requisitos de forma isolada. }\end{array}$ & $\begin{array}{l}\checkmark \text { Os requisitos da Norma estão mais } \\
\text { "integrados" sob ponto de vista } \\
\text { sistêmico.Determinados aspectos do SGQ } \\
\text { são abordados em mais de um requisito, o } \\
\text { que requer dos auditores um maior } \\
\text { aprofundamento em termos de entendimento } \\
\text { do sistema auditado. }\end{array}$ \\
\hline $\begin{array}{l}\checkmark \text { Um dos principais focos da } \\
\text { auditoria era avaliar o } \\
\text { cumprimento dos } \\
\text { procedimentos documentados }\end{array}$ & $\begin{array}{l}\checkmark \text { Um dos principais focos da auditoria é } \\
\text { evidenciar a eficácia dos processos em } \\
\text { atingir os resultados planejados e agregar } \\
\text { valor ao auditado (não se limitar a detectar } \\
\text { não-conformidades) }\end{array}$ \\
\hline
\end{tabular}




\begin{tabular}{||l|l||}
\hline \multicolumn{1}{|c|}{ Era na versão 94...(cont.) } & \multicolumn{1}{c|}{ Como é hoje...(cont.) } \\
\hline$\checkmark$ A padronização era o "fim" & $\checkmark \begin{array}{l}\text { O padrão nada mais é do que início do } \\
\text { processo (sem fim) de melhoria contínua. } \\
\text { (item 0.2 e 8.5.1) }\end{array}$ \\
\hline$\checkmark \begin{array}{l}\text { Requisitos do cliente eram os } \\
\text { explicitados na análise crítica } \\
\text { de contrato }\end{array}$ & $\checkmark \begin{array}{l}\text { Os requisitos relacionados ao produto } \\
\text { incluem os explícitos, os não declarados } \\
\text { pelos clientes e os legais e estatutários. (item } \\
7.2 .1 \text { ) }\end{array}$ \\
\hline$\checkmark \begin{array}{l}\text { Registros da qualidade } \\
\text { serviam essencialmente para } \\
\text { evidenciar conformidade e } \\
\text { deviam ser mantidos }\end{array}$ & $\checkmark \begin{array}{l}\text { Os registros são valiosos para demonstrar a } \\
\text { eficácia do SGQ e seus processos. Mais do } \\
\text { que mantidos, devem ser analisados. (item } \\
\text { 4.2.4 e 8.4) }\end{array}$ \\
\hline
\end{tabular}

\subsection{A proposta para a Abordagem Sistêmica}

Na nova versão da norma, a Abordagem Sistêmica para a Gestão é uma decorrência de outro princípio, o da Abordagem de Processos. A abordagem de processos contribui para a implementação da visão sistêmica, na medida em que permite quebrar os paradigmas de gestão decorrente do uso da estrutura funcional.

Tradicionalmente, as organizações são orientadas para tarefas e adotam a departamentalização funcional (marketing, engenharia, suprimentos, etc.). Este tipo de estrutura oferece a vantagem da qualidade técnica do trabalho, devido à especialização dos profissionais em torno da função, e da otimização dos recursos pessoas, equipamentos, instalações - centralizados, atendendo a toda a empresa.

De acordo com Prieto (2002), a demarcação de territórios comumente leva a organização a apresentar alguns sintomas característicos de perda de velocidade e flexibilidade para atender as demandas do ambiente no qual está inserida. Problemas com cumprimento de prazos, lentidão para solução de problemas, dificuldade das áreas trabalharem em conjunto, sub-otimização das metas organizacionais.

Todos estes problemas vão resultar em uma percepção negativa por parte do cliente, sobre a qualidade do trabalho que lhe é oferecido. Ele é levado de um departamento ao outro para obter as respostas e o atendimento que necessita, o que, muitas vezes poderia ser evitado. O cliente passa a ter que, ele mesmo, fazer a integração. 
Já os processos atravessam as fronteiras dos departamentos. Quando são mapeados e nomeados, evidenciam que o cliente não será atendido satisfatoriamente sem a cooperação ou trabalho conjunto das áreas envolvidas.

A utilização da Abordagem de Processos tem reflexos positivos na gestão organizacional com ênfase na Abordagem Sistêmica, tornando possível definir objetivos para cada um dos processos e não apenas para áreas distintas, o que aumenta a cooperação para o alcance dos objetivos globais.

Com isso também se verifica um aumento do foco no cliente, pois os processos delineiam claramente as entradas e saídas a partir da compreensão das necessidades dos clientes, quer sejam eles internos ou externos. O resultado final é a entrega de valor ao cliente externo, que tem as suas necessidades e expectativas atendidas.

Esta abordagem é compatível com estruturas mais "achatadas". A empresa pode nomear líderes de processos para garantir a coordenação das atividades, ao invés da verticalização da estrutura funcional.

Outro reflexo é o aumento da flexibilidade e da comunicação entre as diferentes funções.

Segundo Prieto (2002), é importante ressaltar que existem diferentes graus de adaptação à abordagem - desde que se mantenha a estrutura funcional e permeando a visão de processos por entre elas até a mudança completa da estrutura.

Ainda segundo este autor, alguns fatores podem contribuir diretamente para $\mathrm{o}$ sucesso da implementação (do sistema): a correta definição dos processos, a percepção da voz do cliente externo e interno, a definição de objetivos para os processos interligados aos objetivos da organização e a competência dos líderes de processos.

\subsection{Auditoria da qualidade e a nova ISO 19011:2002}

Esta Norma não trata apenas da gestão dos programas de auditorias para os Sistemas de Gestão da Qualidade orientados pela NBR ISO 9001, mas também para os Sistemas de Gestão Ambiental balizados pela NBR ISO 14001. Ela cancela e 
substitui as antigas NBR ISO 10011 (partes 1, 2 e 3) de 1993 que traziam diretrizes para auditorias da qualidade e as NBR ISO 14010, 14011 e 14012 de 1996 que traziam diretrizes para auditorias ambiental.

As séries de Normas ISO 9000 e ISO 14000 enfatizam a importância de auditorias como uma ferramenta de gestão para monitorar e verificar a eficácia da implementação da política da qualidade de uma empresa. As auditorias também são uma parte essencial das atividades de avaliação da conformidade, tais como certificação/registro externo e avaliação e acompanhamento da cadeia de fornecedores.

A auditoria é definida nesta norma como sendo um "processo sistemático, documentado e independente para obter evidência de registros, apresentação de fatos ou outras informações, pertinentes e verificáveis e avaliá-los objetivamente para determinar a extensão na qual os conjuntos de política, procedimentos ou requisitos são atendidos".

Ainda segundo com esta Norma a auditoria é caracterizada pela confiança em alguns princípios. Eles fazem da auditoria uma ferramenta eficaz e confiável em apoio a políticas de gestão e controles, fornecendo informações sobre as quais uma empresa pode agir para melhorar seu desempenho.

São considerados princípios relacionados à atuação dos auditores:

$\checkmark$ Conduta ética: o fundamento do profissionalismo. Confiança, integridade, confidencialidade e discrição são essenciais para auditar;

$\checkmark$ Apresentação justa: a obrigação de reportar com veracidade e exatidão. As constatações da auditoria, conclusão de auditoria e relatórios de auditoria refletem verdadeiramente e com precisão as atividades da auditoria. Obstáculos significantes encontrados durante a auditoria e opiniões divergentes não resolvidas entre a equipe de auditores e o auditado são relatados. 
$\checkmark$ Devido cuidado profissional: a aplicação de diligência e julgamento na auditoria. Os auditores devem ter o cuidado necessário considerando a importância da atividade que eles executam e a confiança colocada neles pelos clientes da auditoria e outras partes interessadas.

$\checkmark$ Independência: a base para a imparcialidade da auditoria e a objetividade das conclusões de auditoria. Os auditores são independentes da atividade a ser auditada e são livres de tendência e conflito de interesse.

$\checkmark$ Abordagem baseada em evidência: o método racional para alcançar conclusões de auditoria confiáveis e reprodutíveis em um processo sistemáticas de auditoria. Evidência de auditoria é verificável. É baseada em amostras das informações disponíveis, uma vez que uma auditoria é realizada durante um período finito de tempo e com recursos finitos. $\mathrm{O}$ uso apropriado de amostragem está intimamente relacionado com a confiança que pode ser colocada nas conclusões de auditoria.

Destaca-se nesta norma que o auditor, preferencialmente, tenha boa compreensão técnica e empresarial pertinente às atividades a serem auditadas.

Um programa de auditoria pode incluir uma ou mais auditorias, dependendo do tamanho, natureza e complexidade da empresa a ser auditada. Um programa de auditoria também inclui todas as atividades necessárias para planejar e organizar os tipos e números de auditorias e para fornecer os recursos para conduzi-las eficaz e eficientemente dentro do período de tempo especificado. Na Figura 13 são destacadas algumas destas atividades típicas de uma auditoria. 


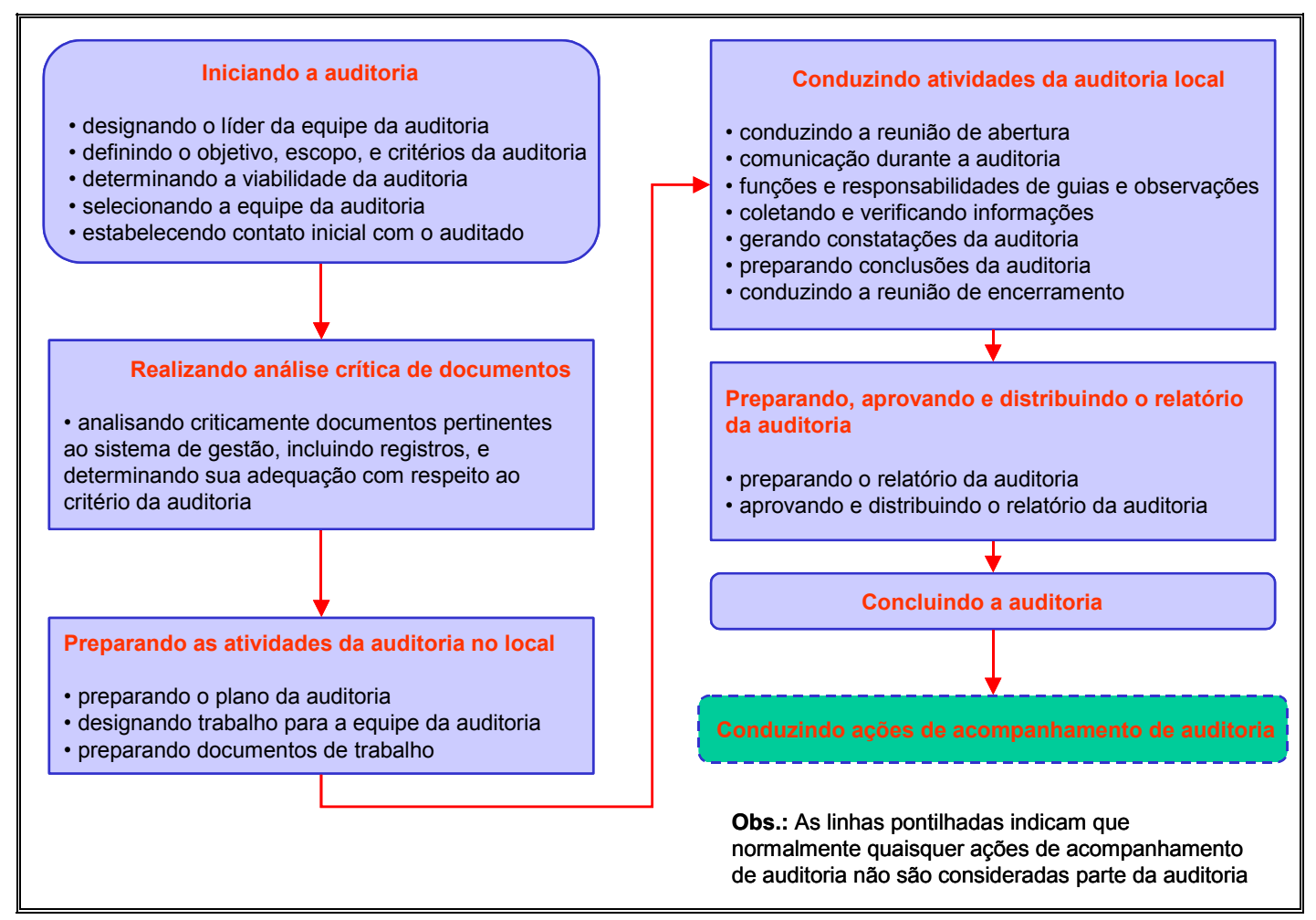

Figura 13 - Visão geral das atividades típicas de auditoria (FONTE: ABNT, 2002)

Dentro dos objetivos de um programa de auditoria, convém que ela seja baseada em objetivos, escopo e critérios documentados. Os objetivos definem o que é para ser realizado, o escopo descreve a abrangência e os limites da auditoria como atividades e processos a serem auditados, bem como o período de tempo coberto pela auditoria. Já o critério da auditoria é usado como uma referência contra a qual a conformidade é determinada e pode incluir políticas aplicáveis, procedimentos, normas, leis e regulamentos, etc.

Segundo a ISO 19001, a segurança e confiança no processo de auditoria dependem da competência daqueles que conduzem a auditoria. Este conceito de competência do auditor está ilustrado na Figura 14. Alguns dos conhecimentos e habilidades descritos são comuns a auditores de sistemas de gestão da qualidade e ambientais; porém, alguns deles são específicos do sistema de gestão a ser auditado. 


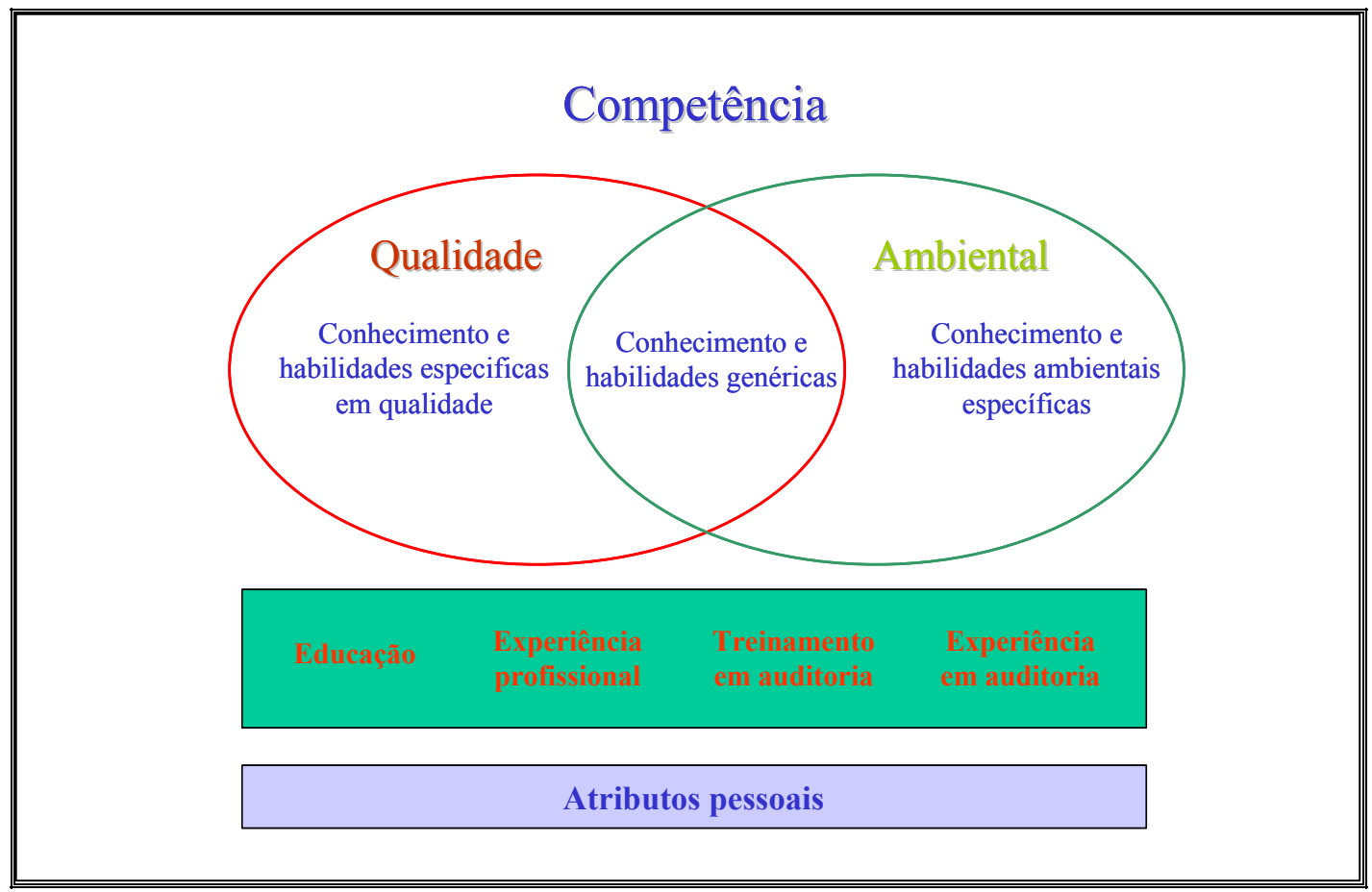

Figura 14 - Conceito de Competência (FONTE: ABNT, 2002)

Os auditores desenvolvem, mantêm e aperfeiçoam a sua competência através do contínuo desenvolvimento profissional e participação regular em auditorias. As avaliações dos auditores são planejadas, implementadas e registradas de acordo com um procedimento do programa de auditoria. O processo de avaliação deve identificar as necessidades de treinamento e outros reforços de habilidade.

A Norma coloca que a avaliação de auditores acontece em três fases.

$\checkmark$ A avaliação inicial de pessoas que desejam se tornar auditores;

$\checkmark$ A avaliação dos auditores como parte do processo de seleção de uma equipe de auditoria;

A avaliação contínua do desempenho de auditores, de modo a identificar necessidades de manutenção e aperfeiçoamento de conhecimento e habilidades.

\subsection{O processo de auditoria na nova versão da ISO 9000}

Desde seu lançamento em 1987, a série ISO 9000 sofreu mudanças e a função qualidade gerou mudanças operacionais profundas, processos foram "enxugados", 
empresas reestruturadas e com essas alterações profissionais dessas empresas migraram para a área de prestação de serviços. Assim com esta migração, o mercado da qualidade, de certificação e de consultoria teve a oportunidade de verificar e absorver profissionais qualificados, mas também muitos profissionais despreparados, necessitando entender conceituação sistêmica e principalmente gestão.

Segundo Jatobá (2002), houve uma acomodação das organizações, dos consultores e auditores, pois na ISO 9001:1994, modelos de sistemas foram desenvolvidos quase que para serem auto-implementados a distância, como se qualidade significasse procedimentos e registros, ou seja, escreva o que se faz e faça o que se escreve. Até livros ou disquetes com modelos estavam disponíveis no mercado.

Mott (2003) diz que o princípio fundamental para obter a certificação ISO 9001:1994 consiste em documentar o sistema da qualidade e, em seguida, executar os processos de trabalho consistentemente, de acordo com os procedimentos documentados. Periodicamente, são exigidas auditorias internas e externas (pela organização certificadora) para comprovar que a empresa continua operando conforme os procedimentos documentados.

Isso tudo gerou burocracia e redundância e até, em alguns casos, ineficiência. Teve, também, é verdade, um lado positivo para algumas empresas: o da padronização de suas atividades. Todavia, a certificação do sistema para a qualidade não é garantia de que o cliente receba o que foi prometido. A conformidade com um processo ruim não terá efeitos diferentes da conformidade com um processo bom.

As empresas certificadas de acordo com a ISO 9001:1994 continuavam produzindo produtos e serviços que não atendiam às expectativas do cliente. Na melhor das hipóteses elas conseguiam identificar e remediar os problemas mais rapidamente. $\mathrm{Na}$ pior, os clientes ficavam mais tranqüilos e com uma ilusória confiança.

Para solucionar esse problema, os autores dessas normas reeditadas resolveram exigir que a organização meça a satisfação dos clientes e utilize esses dados para orientar melhorias contínuas de seus processos de trabalho. 
Com a nova versão da norma, as organizações, consultores e principalmente auditores não encontrarão mais SGQ padrões, e nem tão pouco manuais da qualidade formatados com um procedimento para cada item da norma e suas respectivas instruções de trabalho. Agora, com a ISO 9001:2000, pretende-se que a organização tenha de demonstrar sua identidade, seu negócio, mapear seus processos, mostrar as relações entre eles e criar indicadores que são fundamentais para a gestão do negócio.

Ficou um trabalho mais árduo aos auditores, sejam eles internos ou de terceira parte. As organizações e seus auditores têm agora a tarefa de impedir que os sistemas da qualidade sejam viciados, e levá-los realmente a atender a gestão e os negócios da empresa. Os auditores deverão desenvolver mais a conceituação sistêmica, analisando os clientes da organização, seus requisitos, desdobramento de planos, estratégias, técnicas de melhoria de processos, indicadores, análise de competências, isto é, promover melhorias e agregar valor ao negócio da organização.

Ainda se não bastasse tudo isto, o auditor tem de ter o entendimento de legislação, das normas e requisitos legais que regem o negócio. Saber realmente analisar as exclusões permitidas pela norma ISO. Os auditores deverão planejar bem uma auditoria antes de auditar, checar o mapeamento dos processos, suas interações e criticidades com o negócio, validando assim o sistema de gestão da qualidade implantado, e verificando sua eficácia.

Auditor da ISO 9001:2000 tem de ter em mente que todo sistema pode ser melhorado e fomentar o processo de melhoria contínua. Deve ter a capacidade de entender gestão de processos, estratégia, negócios e resultados. A verdadeira auditoria ISO 9001:2000 irá separar os profissionais qualificados dos profissionais despreparados.

Em reportagem a ISO Management System (2002), o IQNet colocou que a implementação de um SGQ com base na ISO 9001:2000 é muito útil, não apenas para as indústrias de manufatura mas também para os demais setores da indústria como serviço, tecnologia e informação, setores governamentais, etc. Sobre tudo, com as auditorias focadas em abordagem por processos que parecem realçar a efetividade destas auditorias nos SGQ, agregando mais valor à certificação. 
O fato é que a ISO 9001:2000 conduz a uma maior integração, conscientizando os envolvidos sobre as responsabilidades das suas funções e a importância do resultado de cada um com um todo (indicadores de processos). Isso possibilitará maior ênfase ao desempenho da administração e de todos os colaboradores em atender às expectativas dos clientes.

A versão 2000 da ISO 9001 bem implementada e principalmente bem auditada pode ser um instrumento muito útil de gerenciamento global, fornecendo dados para a análise de resultados por processos. As organizações e principalmente os auditores deverão entender os oito princípios definidos na série ISO 9000:2000 (já citados no capítulo 2 item 2.4).

Ao final da auditoria, há uma responsabilidade de agregar valor, otimizar custos e recursos. Criar um verdadeiro ambiente de gestão da qualidade.

\subsection{A certificação ISO $9001: 2000$}

Nem todas as indústrias exigem a certificação dos sistemas de qualidade de seus fornecedores. Se seu cliente não exige a certificação ISO, é preciso questionar se existem razões válidas que justifiquem o investimento necessário, em tempo e dinheiro.

Os melhores motivos para procurar a certificação dos sistemas de qualidade são padronizar as práticas para a qualidade e comprometer-se formalmente a adotar uma cultura de melhoria continua. A versão 1994 determinava a adoção de práticas para a qualidade, eficazes na contenção de defeitos, mas que não eram efetivas para induzir a melhoria. Contudo, é necessário reconhecer que muitas boas empresas certificadas ISO, felizmente, foram além da "conformidade" às normas e adotaram um padrão de desempenho para a melhoria contínua.

O estabelecimento de um objetivo gerencial específico para certificar o sistema de qualidade da organização e a determinação de comprometer-se em longo prazo a preservar a certificação, contribuirá para manter a Direção focada em fazer as "coisas certas". 
Como um conjunto de boas práticas gerenciais, os requisitos da ISO 9001 deveriam ser seguidos pela organização como mecanismo básico de se prevenir a ocorrência de problemas. Porém, a situação mais comum é o sistema ser "atropelado" por ações de "bombeiros" - não se faz planejamento da qualidade porque é necessário entregar o produto, não se analisam os requisitos do produto e a capacidade do processo, pois temos de gerar receita, o produto não é entregue porque se esqueceram de avaliar os requisitos do cliente de forma completa, os problemas reais não são registrados para não se criar problemas com o cliente e com o auditor, e assim por diante.

Aliado a um sistema geralmente fraco com relação às ações corretivas, preventivas e análises críticas do sistema, entra-se em um ciclo vicioso difícil de ser rompido sem uma visão coerente e clara sobre a real função de um sistema de gestão da qualidade: auxiliar a organização a fazer melhor suas atividades - se essa função não está sendo cumprida, a única conclusão possível é que o sistema não está sendo eficaz e deve ser alterado. Com o advento da ISO 9001:2000, todos os profissionais da área esperam que esse objetivo básico da norma seja cumprido. Por outro lado, até que ponto a norma em si será capaz de produzir essa alteração de foco é fonte para outras discussões.

Assim como houve um grande crescimento no número de certificados emitidos, várias empresas especializadas em consultoria em qualidade surgiram para atender a forte demanda por especialistas em qualidade, particularmente quando à série ISO 9000. Como decorrência natural das pressões de mercado, os serviços são alocados às empresas de consultoria que propõem a implementação do sistema de gestão da qualidade ao menor custo e no menor prazo. Apesar de inicialmente interessante, essa escolha da organização pode trazer conseqüências ruins - o sistema tende a ser “distante" da realidade da organização, de suas necessidades e, principalmente, longe de cumprir sua função básica: melhorar as atividades da organização.

Por último, pode-se citar as dificuldades relacionadas ao processo de certificação em si - o coroamento do processo de implementação de um projeto ISO 9000 é centralizado no organismo de certificação. Sem dúvida, uma enorme responsabilidade para o organismo de certificação. 
Deve-se salientar as limitações do processo de auditoria: é uma avaliação limitada em termos de tempo, com um tempo de planejamento e preparação reconhecidamente insuficientes em que apenas um dos auditores (normalmente, o líder da equipe) avaliou e tem conhecimento do sistema documentado do cliente. Durante a auditoria de campo, o auditor deve avaliar, por amostra, a aderência da organização aos requisitos da norma - como exemplo temos que, para o dimensionamento de uma auditoria em uma empresa de 250 funcionários, seguindo as recomendações da NIT DICOR 037 do INMETRO, a auditoria de campo em ISO 9001 deveria ser realizada em oito dias, portanto aproximadamente, 2 horas e 24 minutos para cada elemento da norma. Suficiente? Dificilmente para uma avaliação profunda da eficácia do sistema.

Aliados a esse fator limitante, alguns profissionais fazem da auditoria um processo complexo: a falta de experiência dos auditores, a inflexibilidade na interpretação da norma, assim como a incorreção de algumas interpretações, a tendência de impor opiniões e sistemas vistos em outras organizações, a falta de uniformidade entre auditores e organismos de certificação na forma de atuação e interpretação dos requisitos da norma, entre outros.

Sem dúvida, querer acusar e responsabilizar o organismo de certificação pela percepção negativa do processo de certificação é, no mínimo, simplificar a análise. Da mesma forma, esperar que a ISO 9001:2000 solucione esses problemas é um tanto quanto leviano na tentativa de eximir da responsabilidade de criar um sistema que seja cada vez mais confiável.

$\mathrm{Na}$ verdade, somente com a conscientização de todos os envolvidos é que haverá o início de alguma mudança nesse processo: em primeiro lugar, reconhecendo que todos são responsáveis por essa percepção negativa, e em segundo, que cabe aos profissionais do mercado da qualidade e também aos empresários mudar essa perspectiva. 


\section{Estudos de Caso}

Para a complementação desta pesquisa, foi necessário o estudo de caso em algumas empresas. Este estudo de caso envolveu quatro empresas construtoras que atuam nas áreas de incorporação, construção habitacional, comercial, industrial e de obras públicas.

Estas empresas foram escolhidas por apresentarem características importantes para o desenvolvimento do trabalho, uma vez que elas passaram recentemente por um processo de adaptação/atualização dos seus Sistemas de Gestão da Qualidade para se enquadrarem ao modelo proposto pelos requisitos da NBR ISO 9001:2000.

Para o atendimento ao objetivo proposto, utilizou-se como metodologia para levantamento de dados a aplicação de questionários junto às empresas através da realização de entrevistas com os principais envolvidos no processo de adaptação do sistema e também com a equipe técnica. Foram realizadas visitas nos canteiros de obras para verificar junto à equipe de produção quais foram os impactos e resultados práticos com esta nova abordagem.

\subsection{Empresa A}

Trata-se de uma empresa construtora que atua na área de habitação popular, incorporação imobiliária de médio padrão e construções de galpões industriais utilizando recursos próprios, de terceiros, financiados pelo programa habitacional da Caixa Econômica Federal e com recursos da CDHU. Ela atua em todo estado de São Paulo - SP.

Desde a sua fundação em 07/04/1983, há quase 20 anos, foram entregues 66 obras, sendo 10 de incorporações, 40 da CDHU e 16 obras industriais. No período em que ocorreu a pesquisa ela estava como 15 obras em andamento totalizando $80.000 \mathrm{~m}^{2}$, possuindo um total de 400 funcionários sendo 100 deles atuando no escritório central.

A estrutura organizacional caracteriza-se essencialmente pela centralização de toda a autoridade na alta direção, constituída pelos seus três sócios. As obras são 
administradas através das gerências de obras. A Figura 15 apresenta a distribuição hierárquica da autoridade dentro da empresa $\mathrm{A}$.

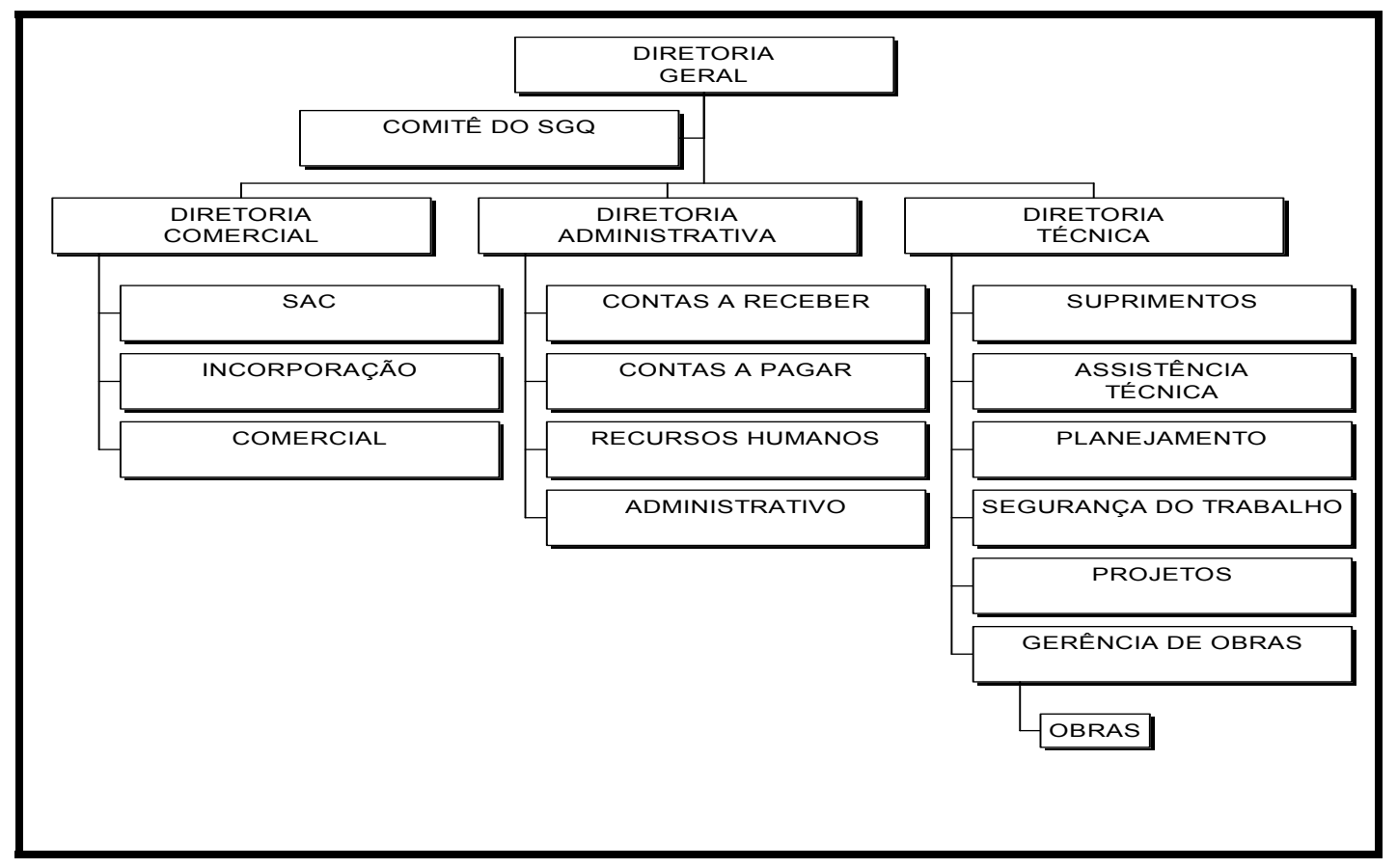

Figura 15 - Organograma funcional da empresa A. (Fonte: empresa A)

$\mathrm{Na}$ busca pelo aumento da participação da empresa no mercado, tendo como objetivo principal o aumento de sua competitividade, a Direção tem adotado algumas ações na busca deste objetivo. A Tabela 5 traz algumas destas ações. 
Tabela 5: Ações tomadas visando aumento da competitividade

\begin{tabular}{|c|c|}
\hline Ações tomadas... & Visando... \\
\hline 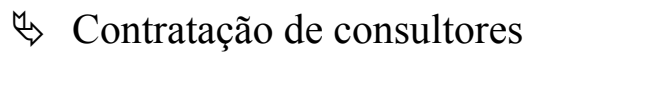 & $\begin{aligned} \stackrel{4}{\hookrightarrow} \text { Atualização de suas técnicas } \\
\text { construtivas e gerenciais. }\end{aligned}$ \\
\hline $\begin{array}{l}\Leftrightarrow \text { Parcerias com fornecedores e } \\
\text { subempreiteiros }\end{array}$ & 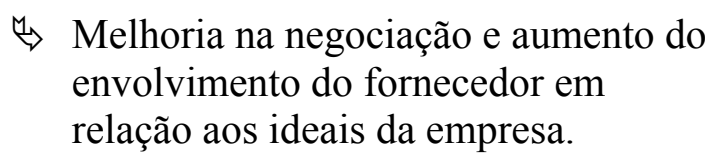 \\
\hline$\Leftrightarrow$ Parcerias com outras construtoras & $\begin{array}{l}\Leftrightarrow \text { Troca de experiências e aumento da } \\
\text { possibilidade de novos negócios. }\end{array}$ \\
\hline $\begin{array}{l}\text { (4) Investimento em sistemas } \\
\text { informatizados }\end{array}$ & $\begin{array}{l}\Leftrightarrow \text { Agilizar a troca de informações entre } \\
\text { os diversos setores da empresa. }\end{array}$ \\
\hline $\begin{array}{l}\Leftrightarrow \text { Investimento em planejamento da } \\
\text { produção. }\end{array}$ & 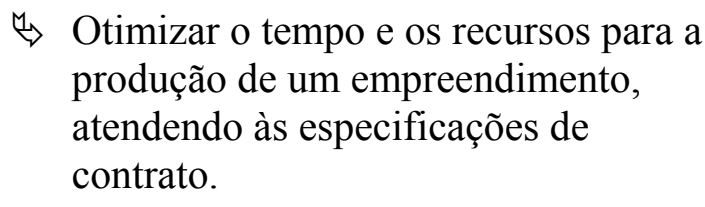 \\
\hline$\Leftrightarrow \begin{array}{l}\text { Investimento e Segurança do } \\
\text { Trabalho }\end{array}$ & $\begin{array}{l}\text { H. Criar uma cultura entre os } \\
\text { funcionários da importância do } \\
\text { ambiente de trabalho seguro e } \\
\text { também minimizar as ausências por } \\
\text { acidente de trabalho }\end{array}$ \\
\hline$\stackrel{\leftrightarrow}{\rightarrow}$ Reuniões com os funcionários & $\begin{array}{l}\Leftrightarrow \text { Integração e a melhoria do } \\
\text { desempenho a empresa, criando um } \\
\text { ambiente onde os funcionários se } \\
\text { sentissem como peças chave da } \\
\text { empresa. }\end{array}$ \\
\hline
\end{tabular}

Atualmente o sistema de gestão da qualidade está concentrado na função do coordenador da qualidade, sendo que a pessoa que ocupa este cargo atualmente atua na empresa há quatro anos.

A primeira qualificação foi em 1998 com base nos requisitos do QUALIHAB, devido às exigências impostas pela CDHU para a realização de suas obras. Para esta certificação contou com a ajuda da empresa de consultoria CTE - Centro de Tecnologia de Edificações para implementação de seu sistema de gestão da qualidade.

De acordo com o seu coordenador da qualidade não foi possível avaliar se com a implantação do antigo SGQ a empresa obteve melhoria de seu desempenho, pois não 
havia dados concretos e confiáveis de indicadores de monitoramento deste desempenho.

Como principais pontos negativos levantados foram:

$\checkmark$ Sistema burocrático em demasia ("engessado");

$\checkmark$ Documentação em excesso;

$\checkmark$ Dificuldade dos funcionários entenderem a importância do SGQ.

Em março de 2002 a empresa iniciou um processo de atualização e simplificação de seu Sistema de Gestão da Qualidade para adequação aos requisitos da NBR ISO 9001:2000. Em janeiro de 2003 a empresa se certificou no nível A do SiQ-C do PBQP-H, porém apesar de ter se adequado à versão 2000 da ISO 9001 a empresa não se sentiu preparada para esta auditoria de certificação.

Para a atualização em seu sistema a empresa proporcionou ao coordenador da qualidade cursos de atualização e de formação de auditores internos, além da contratação da mesma empresa de consultoria para ajudá-la nesta nova fase. Internamente formaram-se grupos de trabalho que analisavam as propostas de mudanças e as formatavam adequando-as à realidade de seus processos.

Atendendo às exigências da Norma, a empresa se viu obrigada a elaborar seu macrofluxo de processos (Figura 16) identificando quais seriam os principais "gargalos" em cada um deles.

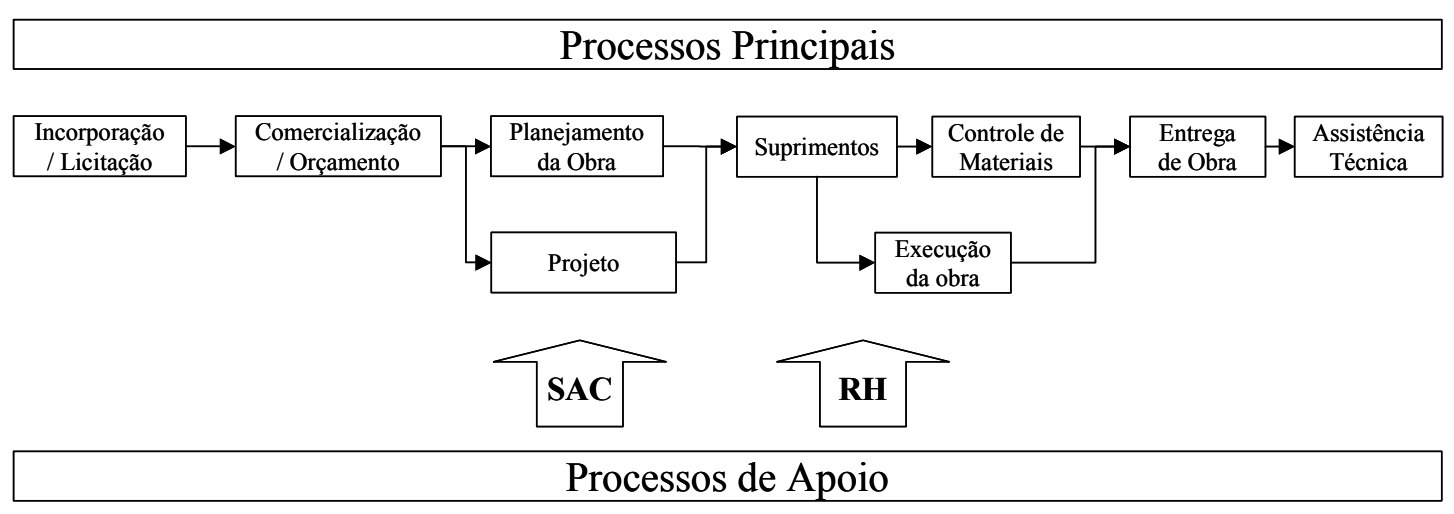

Figura 16 - Macro-fluxo de processo da empresa A. (Fonte: empresa A) 
Dentre as diversas mudanças exigidas pela nova versão da ISO 9001, o coordenador da empresa identificou o requisito que trata da Análise Crítica pela Direção (requisito 5.6) como sendo um dos mais importantes e aquele que mais necessita da preparação, organização e empenho para obter todo o resultado a que este item se propõe. De acordo com o Coordenador da Qualidade "a grande dificuldade na preparação da reunião de $\mathrm{ACD}$, verificou-se pelo fato da obrigatoriedade da análise de todos os itens exigidos no requisito específico para este fim constante da Norma, e ainda sendo mais objetiva possível".

O canteiro de obras foi identificado, pelo Coordenador, como principal setor que sofrerá as maiores mudanças com esta nova linha da norma; ele acredita que as equipes de obra ainda possuem uma atitude reativa com relação ao SGQ, explicado talvez pelas experiências anteriores. O Sistema inicialmente montado pela empresa se tornou extremamente burocrático, tornando os processos internos altamente improdutivos e por muitas vezes sem garantir a qualidade do produto final, isto é, totalmente ineficaz.

Nesta nova etapa, notou-se uma mudança nesta atitude; as equipes perceberam que poderiam implementar as mudanças enfocando a manutenção do SGQ de forma mais prática e objetiva, sem a necessidade de se criar inúmeros documentos para controlar um único processo.

Nas obras da empresa são criados Comitês da Qualidade da Obra que normalmente são compostos pelo engenheiro residente, mestre de obras, administrativo, encarregado, almoxarife e estagiário. O engenheiro é o principal responsável pela manutenção e evolução do SGQ no âmbito da obra, como por exemplo:

$\checkmark$ Propor a melhoria e a racionalização dos processos de obra;

Aproximar as equipes de produção para discussão de problemas;

Promover o treinamento e o acompanhamento da implantação dos procedimentos padronizados;

$\checkmark$ Criar um canal de comunicação entre a obra e o Comitê Central da Qualidade. 
Com relação às mudanças, um dos engenheiros da empresa coloca que o maior desafio será o entendimento dos objetivos da qualidade por parte da equipe de campo. Ele ainda esclarece que no passado os dados eram levantados sem que se houvesse a preocupação de se saber a sua finalidade e muito menos se os resultados obtidos eram satisfatório.

Para tentar minimizar este problema são realizadas reuniões com equipe administrativa da obra, explicando cada um dos objetivos e qual a sua finalidade, mostrando inclusive os resultados. A equipe administrativa terá a responsabilidade de passar estas informações para toda a equipe de produção, mesmo tendo sido colocado que a obrigatoriedade do conhecimento destes objetivos se limitariam, na obra, para as funções administrativas e gerenciais.

Os objetivos criados para monitorar os processos de produção são mostrados na Tabela 6. Não foram passados pela empresa os resultados alcançados.

Tabela 6: Objetivos, indicadores e metas para os processos de produção (Fonte: Empresa A).

\begin{tabular}{|c|c|c|}
\hline Objetivo & Indicador & Meta \\
\hline \hline $\begin{array}{c}\text { Redução do } \\
\text { retrabalho }\end{array}$ & $I=\frac{n^{o} \text { de rejeição por Serviço }}{n^{o} \text { insp. realizadas por Serviço }} \times 100$ & $I \leq 30 \%$ \\
\hline $\begin{array}{c}\text { Reduzir falhas na } \\
\text { entrega }\end{array}$ & $I=\frac{n^{0} \text { de unidades com pendências }}{n^{0} \text { de unidades entregues }} \times 100$ & $I \leq 10 \%$ \\
\hline $\begin{array}{c}\text { Cumprimento do } \\
\text { planejamento }\end{array}$ & $I=\%$ prevista $-\%$ executata & $I \leq 5 \%$ \\
\hline \hline
\end{tabular}

Com o intuito de envolver toda a equipe técnica na busca pela melhoria contínua, a empresa institucionalizou o "Dia da Crítica". Nesse dia todos os seus engenheiros fazem uma reunião em uma das obras em andamento para observar as boas práticas aplicadas naquele canteiro e também para criticar as falhas encontradas. As reuniões são realizadas uma vez por mês sendo feito um rodízio entre as obras.

"Muitos problemas de execução são comuns entre as obras e com isso pode-se observar o que foi feito em um outro canteiro ou até mesmo descobrir uma solução através de uma 'crítica' de outros colegas", comenta um dos engenheiros. 


\subsection{Empresa B}

A construtora B é uma empresa que atua no setor de edificação residencial de alto e médio padrão e também com escritórios comerciais. Todas as obras contratadas por administração e a preço fechado.

Sua fundação ocorreu há quase 13 anos, em dezembro de 1990, e desde lá já foram entregues 12 obras. Atualmente estão com três obras em andamento totalizando $29.000 \mathrm{~m}^{2}$ de área em construção.

A empresa possui uma diretoria formada por dois de seus sócios, sendo que um deles atua na área de marketing e o outro atua na área comercial e técnica da empresa. As obras são gerenciadas pelos engenheiros responsáveis e supervisionada por um coordenador de obras. Na Figura 17 é apresentado o organograma da empresa B.

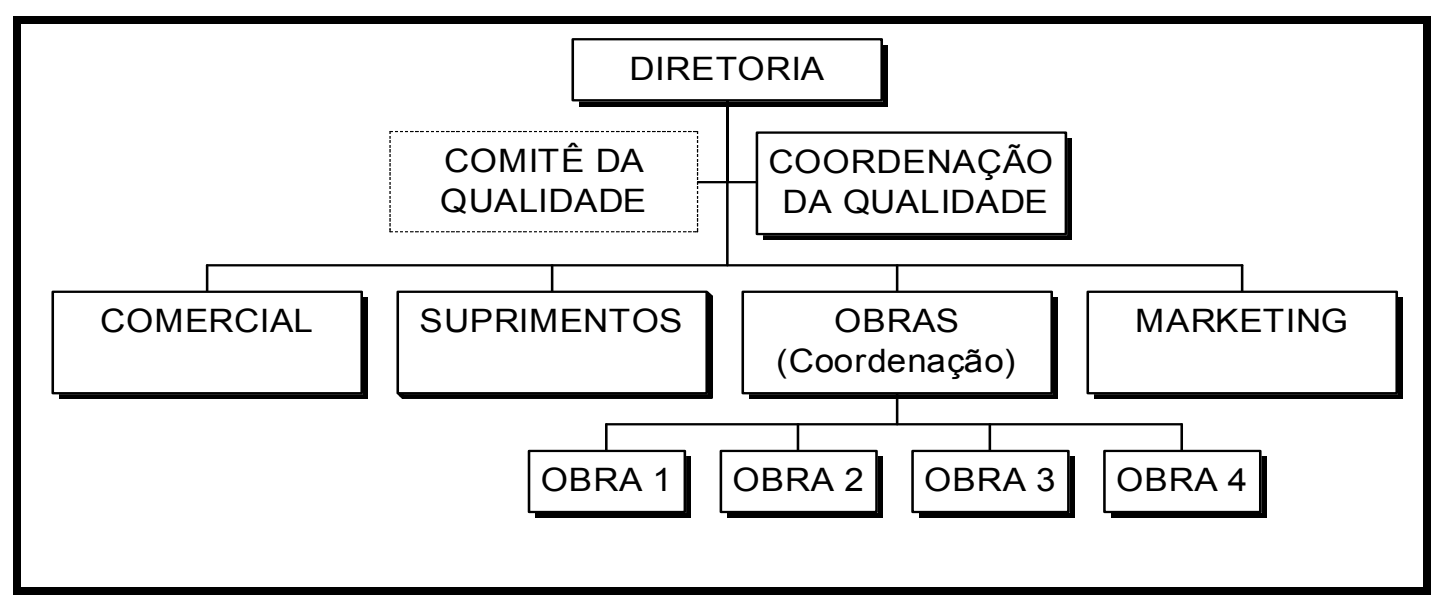

Figura 17 - Organograma funcional da empresa B. (Fonte: empresa B)

Como estratégias internas para a manutenção da competitividade da empresas, a direção adota certas políticas como:

$\checkmark$ Renovação e locação dos equipamentos de produção;

$\checkmark$ Utilização de serviços de consultores nas áreas técnicas e gerenciais da empresa;

$\checkmark$ Estabelecimento de parcerias com projetistas, fornecedores e outras construtoras;

$\checkmark$ Investimento em marketing e informática; 
Preocupação com a Segurança do trabalho;

Participação no grupo de construtoras para desenvolvimento contínuo (GEC Grupo de Evolução Conjunta com outras 11 empresas).

Para o gerenciamento do Sistema de Gestão da Qualidade a empresa possui um Comitê da Qualidade tendo como membros a Diretoria, o Coordenador de Obras e o Engenheiro de Custos, sendo este último o Coordenador da Qualidade e nomeado pela direção como sendo o Representante da Direção para o SGQ.

Primeiramente a empresa obteve a certificação com base na versão de 1994 da NBR ISO 9002, em dezembro de 1999. Para o processo de implementação de seu SGQ a empresa contou com o auxílio do CTE na elaboração da documentação exigida pelo sistema.

Segundo seu RD “inicialmente a conscientização foi uma barreira”. Ele coloca que foi necessário um trabalho muito intenso entre palestras, reuniões e treinamentos dos funcionários até que se obtivesse o engajamento de todos dentro da empresa.

Com relação à documentação ele afirma que foram identificados alguns procedimentos documentados que não eram totalmente utilizados, pois suas informações não eram necessariamente imprescindíveis para a execução, com a qualidade exigida, das atividades ou serviços de obra. Ele alerta ainda que o requisito relativo à calibração de equipamento de medição foi aquele que apresentou maiores dificuldades no processo de implantação.

Questionado sobre a melhoria do desempenho da empresa após a implantação do Sistema, o RD coloca que aparentemente houve uma melhora porém sem muitos dados concretos. Os índices médios de satisfação dos clientes obtidos a partir da implantação foram considerados satisfatórios, apesar de não se ter índices anteriores à implantação. Outro fator que é considerado como melhoria a partir da existência do Sistema é a média das notas dos fornecedores, que passou de 70 para 91.

No início de 2002, mais exatamente em abril deste ano, a empresa com o auxílio da consultoria do CTE iniciou o processo de atualização e também de simplificação de 
seu SGQ. E em dezembro de 2002 foi certificada pela FCAV atendendo todos os requisitos na NBR ISO 9001:2000.

Todo o processo ficou centralizado nas mãos do $\mathrm{RD}$, sendo que alguns assuntos específicos eram discutidos em reuniões com os principais envolvidos e a diretoria da empresa. Verificou-se que, além do RD, o Coordenador das obras participou ativamente da reestruturação da documentação do Sistema.

Com o avanço do processo de análise da Norma e adequação da sua documentação a empresa acabou por identificar como principal item a ser tratado o Monitoramento dos processos. Assim a direção da empresa decidiu elaborar um fluxo de processos detalhado, não só para atender às exigências normativas, mas com o intuito de conhecer melhor seus processos internos de produção. A Figura 18 traz este fluxo. 


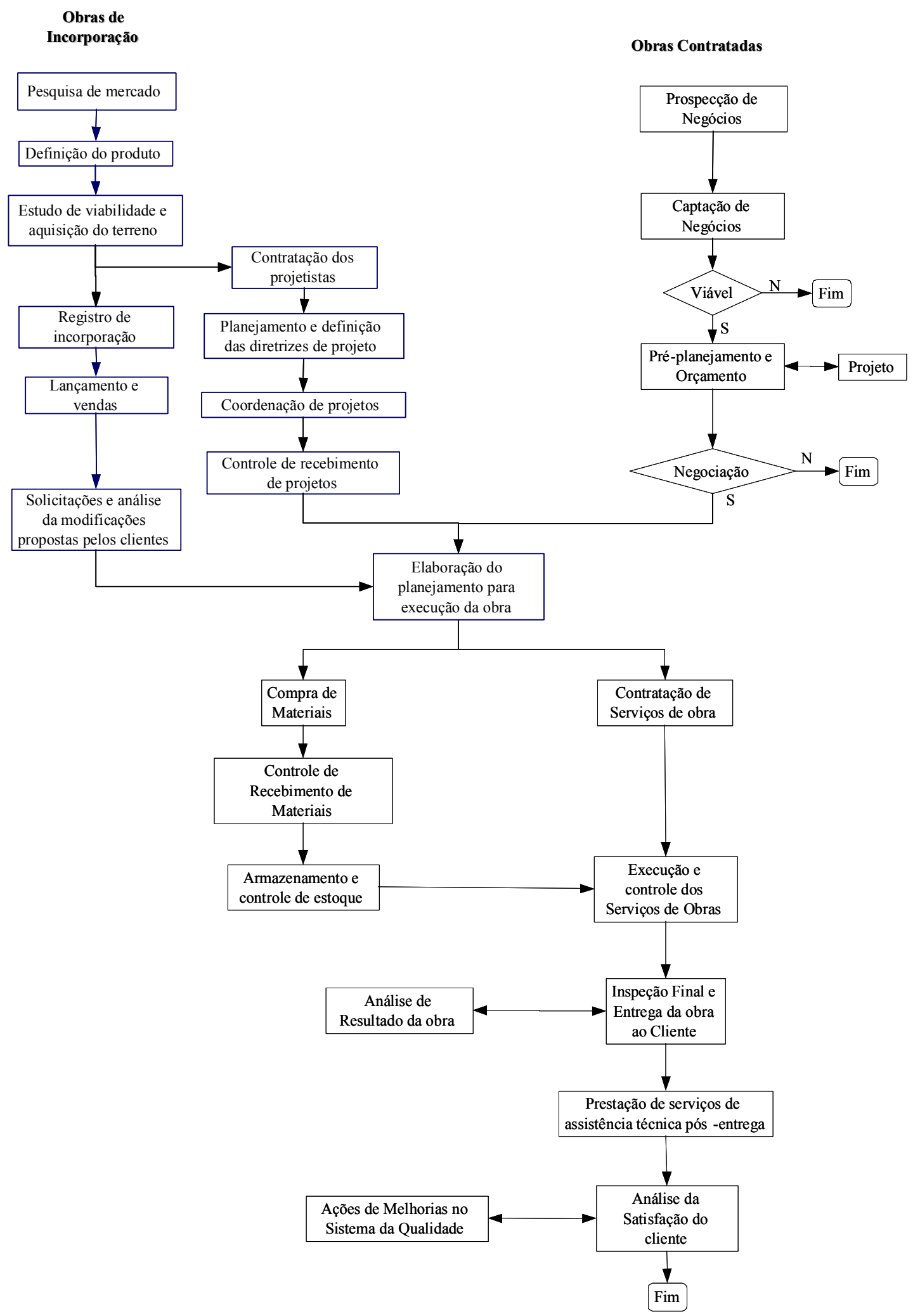

Figura 18 - Macro fluxo de processo da empresa B. (Fonte: empresa B)

Em análise desta nova versão da Norma, o RD da empresa coloca que um dos principais requisitos é aquele que trata do monitoramento dos processos e dos 
produtos. Ele esclarece que estes requisitos implantados corretamente podem trazer informações importantes para tomada de decisões estratégicas e operacionais dentro da construtora.

Entre o início dos trabalhos de adequação e a certificação do sistema de gestão já orientado sob a ótica da versão 2000, foi identificado que o controle de equipamentos de medição continua sendo um dos pontos fracos, ele declara também que "no processo de aquisição sempre aparece um ou outro problema necessitando especial atenção".

Um dos principais desafios identificados já neste início de novo SGQ foi que todos os departamentos, inclusive a Direção, terão que se adaptarem a levantar os dados dos indicadores da qualidade, pois "não mais só o 'comitê' tem a responsabilidade de manter o sistema 'rodando"”, desabafa o RD da empresa.

No setor de Planejamento foi elaborado um procedimento documentado em conjunto com o consultor da área; isto foi necessário para que, além de atender os requisitos obrigatórios, este processo fosse realmente posto em prática e buscasse alcançar os objetivos.almejados pela empresa

A grande expectativa da empresa com a adequação aos novos requisitos é que se consiga uma melhoria geral de seu SGQ, com uma documentação "enxuta” e prática. Buscando um aumento na produtividade e redução dos desperdícios. E, é claro, tendo como foco principal o aumento da competitividade da empresa.

As obras da empresa possuem uma equipe que atua como um comitê da qualidade local, tendo a função de manter o Sistema e promover as melhorias necessárias à obra.

São membros dessa equipe o Engenheiro, Mestre de Obras, Almoxarife e Estagiário. A função de cada um deles está muito bem definida, no Plano de Qualidade do Empreendimento, através de uma matriz de responsabilidades. O Engenheiro como, o topo da pirâmide do organograma da obra, possui a entre outras funções a de manter o canal de comunicação aberto entre a obra e o escritório central da empresa. 
Foi declarado pelo engenheiro, que o desafio maior, para a adequação do Sistema, foi inicialmente de explicar a função de cada um dos objetivos, seus indicadores e metas, que foram criados para monitorar os processos produtivos.

Foram feitas várias reuniões para esclarecer que a função desse monitoramento era a de analisar os processos produtivos, suas possíveis falhas, deficiências e oportunidades de melhorias. Muitos já pensavam que a função principal deles era monitorar o trabalho das pessoas, o que causou um certo desconforto inicial entre a equipe, comenta o Engenheiro.

Os objetivos criados para monitorar os processos de produção são mostrados na Tabela 7.

Tabela 7: Objetivos, indicadores e metas ligadas ao processo produção (Fonte: Empresa B)

\begin{tabular}{|c|c|c|}
\hline Objetivo & Indicador & Meta \\
\hline $\begin{array}{l}\text { Redução do } \\
\text { retrabalho nos } \\
\text { serviços } \\
\text { controlados }\end{array}$ & $I=\frac{n^{o} \text { de rejeição por Serviço }}{n^{o} \text { insp.realizadas por Serviço }} \times 100$ & $I \leq 35 \%$ \\
\hline $\begin{array}{l}\text { Melhorar o nível de } \\
\text { organização dos } \\
\text { canteiros }\end{array}$ & $I=$ Nota de canteiro por check-list. & $I \geq 8,0$ \\
\hline $\begin{array}{l}\text { Incluir novas } \\
\text { tecnologias nos } \\
\text { processos da } \\
\text { empresa }\end{array}$ & $\begin{array}{c}I=N^{o} \text { de inovações utilizadas com resultado } \\
\text { satisfatório }\end{array}$ & $\begin{array}{l}I \geq 2 \text { por } \\
\quad \text { obra }\end{array}$ \\
\hline $\begin{array}{l}\text { Reduzir o número } \\
\text { de pendências no } \\
\text { check-list final de } \\
\text { entrega }\end{array}$ & $\begin{array}{c}I=\text { Número de pendências por check-list final de } \\
\text { entrega }\end{array}$ & $\begin{array}{l}I \leq 2 \text { por } \\
\text { check-list }\end{array}$ \\
\hline $\begin{array}{l}\text { Reduzir o número } \\
\text { de pendências por } \\
\text { serviço no } \\
\text { momento da } \\
\text { entrega }\end{array}$ & $I=n^{\circ}$ de pendência por item com pendência & $\begin{array}{l}I \geq 50 \\
\text { pontos }\end{array}$ \\
\hline $\begin{array}{l}\text { Reduzir o número } \\
\text { de pendências } \\
\text { verificadas pelo } \\
\text { cliente no momento } \\
\text { da entrega }\end{array}$ & $I=\frac{n^{0} \text { de pendências }}{n^{0} \text { de unidades entregues }}$ & $\begin{array}{l}I \leq 2 \% \text { por } \\
\text { empreendim } \\
\quad \text { ento }\end{array}$ \\
\hline
\end{tabular}


A avaliação dos indicadores é feita normalmente a cada seis meses para subsidiar a reunião de $\mathrm{ACD}$, porém o levantamento dos dados é extremamente dinâmico. Dependendo do indicador os dados são coletados diariamente e compilados mensalmente.

Os resultados de todos os indicadores são fixados nos murais das obras para conhecimento de todos. Antes disso é realizada uma reunião em cada obra quando o Engenheiro detalha esses resultados. Essas reuniões contam com a presença apenas do Mestre, Almoxarife, Encarregados e estagiários.

Foi apresentado para os resultados dos indicadores relativos aos processos de produção para o ano de 2003 que marca o início do novo modelo de Sistema.

A Figura 19 mostra a evolução do indicador que monitora o nível de organização dos canteiros de obras da empresa.

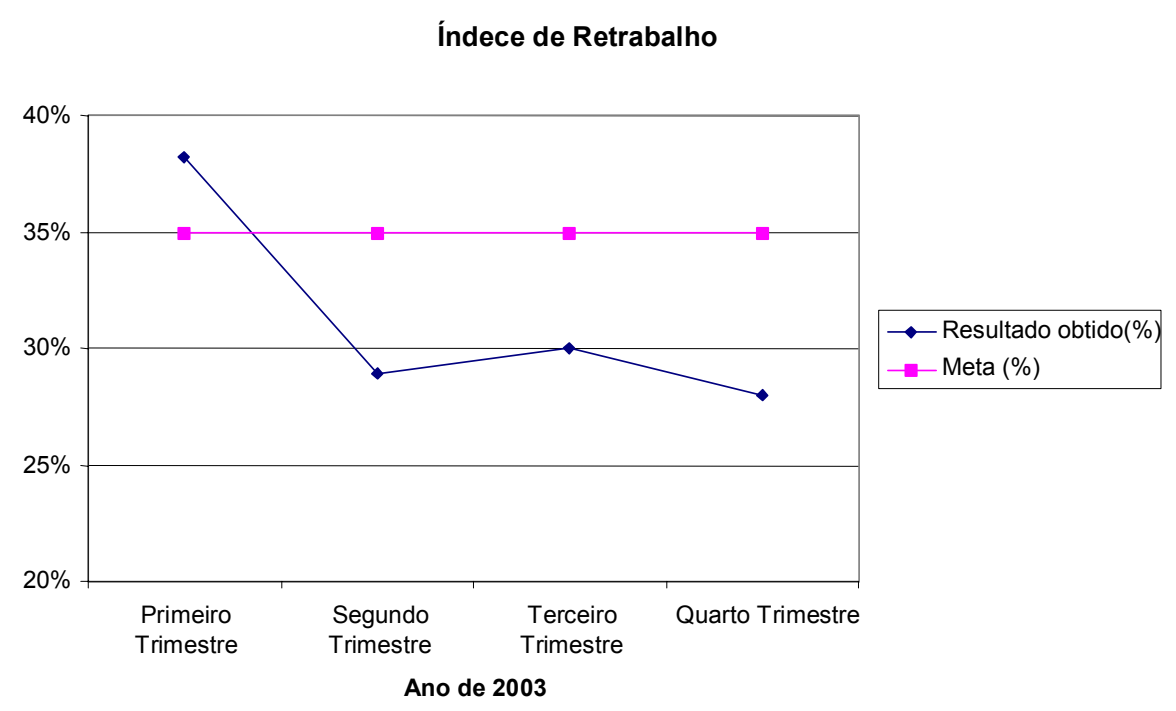

Figura 19 - Evolução do indicador de retrabalho nas obras. (Fonte: Empresa B)

A análise logo no primeiro trimestre mostrou que o pessoal da obra não estava coletando corretamente os dados para alimentar este indicador. Não estava sendo levado em conta o número de inspeções para cada serviço, que é obtido pelo número de itens de inspeções de um determinado serviço multiplicando-se pelo número de amostras tomadas, e sim somente número de itens constante nas ficha de inspeções. Essa diferença em alguns casos pode distorcer os resultados. 
Depois dessa falha inicial, os resultados obtidos foram satisfatórios e mostraram também que a empresa pode ser mais ousada para o próximo ano. E de acordo com o Coordenador de obras, já foi solicitada pela Alta Direção que se estipule nova meta para este indicador.

O outro indicador é mostrado na Figura 20 mostra a evolução do indicador que monitora o nível de organização dos canteiros de obras da empresa.

\section{Nota no Check-list de canteiro}

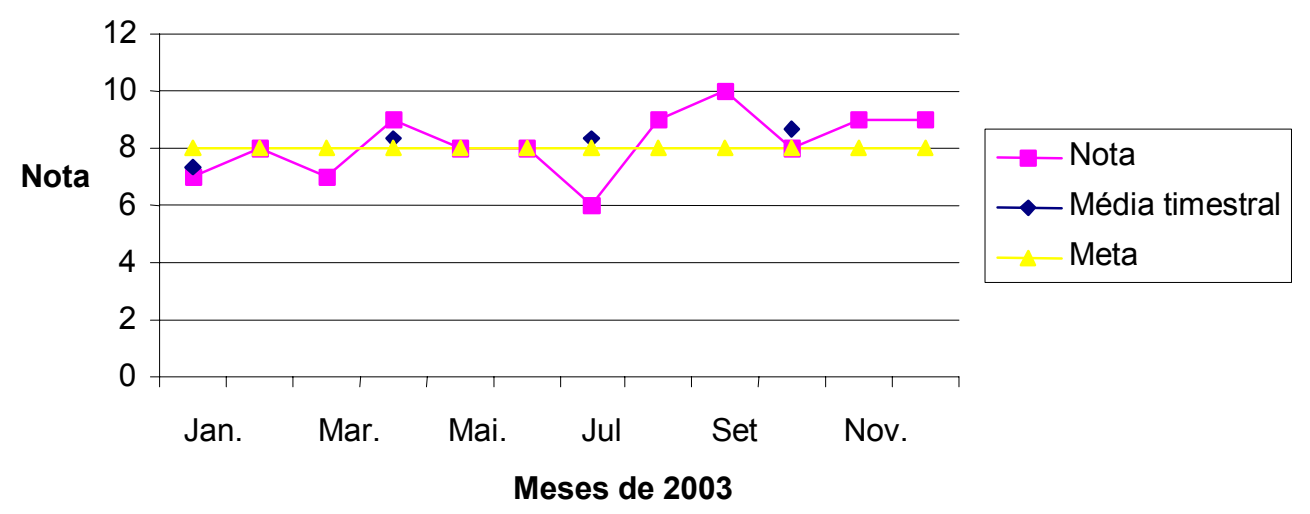

Figura 20 - Evolução do indicador de organização do canteiro (Fonte: Empresa B)

Com relação ao reflexo desses indicadores notou-se um envolvimento das equipes de obra não só da equipe administrativa, mas também das equipes de produção. Isso foi percebido pelo interesse dessa equipe de produção em saber dos resultados, em especial aquele relativo ao monitoramento da organização do canteiro.

Foi declarado pelo Mestre de obras que se criou um certo sentimento de rivalidade, sadia acrescenta ele, entre as obras. As equipes estavam realmente preocupadas em manter o nível de organização do canteiro para não correr o risco de se obter nota baixa na avaliação do Coordenado de Obras.

Essa avaliação é realizada uma vez por mês, utilizando-se um check-list (Anexo C), onde o Coordenador de Obras avalia diversas condições do canteiro.

O indicador que trata das inovações com resultado satisfatório não foi analisado pois de acordo com o Coordenador da Qualidade, os engenheiros não souberam 
identificar as pequenas inovações que foram implementadas. Para o próximo período de análise a Direção decidiu por manter este objetivo e os Engenheiros ficaram de se esforçar na busca da meta colocada.

O processo de entrega não foi possível avaliar pois no período após a implementação do novo modelo de Sistema de Gestão a empresa não finalizou nenhuma obra. 


\subsection{Empresa $C$}

A terceira empresa estudada, aqui denominada empresa $\mathbf{C}$, atua com construções de edificações residenciais de médio e alto padrão e habitação popular, escritórios comerciais e também com uma pequena participação em recuperação de galpões industriais. O tipo de contrato de venda e construção varia conforme a tipologia das edificações, conforme Tabela 8.

Tabela 8: Formas de contratação da empresa C

\begin{tabular}{|c|c|c|}
\hline Tipologia & Contrato de Venda & "Contrato de Construção \\
\hline$\stackrel{\leftrightarrow}{\rightarrow}$ Habitação popular & $\begin{aligned} & \Leftrightarrow \text { Preço de custo e } \\
& \text { preço fechado }\end{aligned}$ & $\Leftrightarrow$ Empreitada global \\
\hline 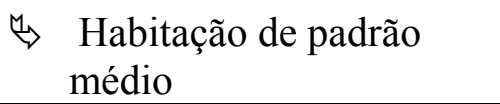 & $\begin{aligned} & \Leftrightarrow \text { Preço de custo e } \\
& \text { preço fechado }\end{aligned}$ & $\stackrel{\leftrightarrow}{\leftrightarrow}$ Empreitada global \\
\hline$\Leftrightarrow$ Habitação de padrão alto & $\Leftrightarrow$ Preço fechado & $\stackrel{\leftrightarrow}{\rightarrow}$ Empreitada global \\
\hline$\stackrel{\leftrightarrow}{\rightarrow}$ Escritórios & $\stackrel{\begin{array}{l}\text { Preço de custo e } \\
\text { preço fechado }\end{array}}{ }$ & $\Leftrightarrow$ Empreitada global \\
\hline $\begin{array}{l}\Leftrightarrow \text { Recuperação de galpão } \\
\text { industrial }\end{array}$ & $\Leftrightarrow$ Preço de custo & $\Leftrightarrow$ Empreitada global \\
\hline
\end{tabular}

Ela atua no mercado desde 1988, ano de sua fundação e já entregou um total de 25 obras. Estão em andamento seis obras totalizando $30.000 \mathrm{~m}^{2}$ de área em construção.

A empresa sempre buscou a utilização de novas tecnologias em suas obras, porém só utilizam aquelas testadas e aprovadas pelo mercado. Não é uma das características estratégicas da empresa se aventurar no desenvolvimento de tecnologias. A empresa se utiliza, por exemplo, de consultores de diversas especialidades para manterem atualizadas as práticas da empresa.

É comum também o investimento na capacitação de seus funcionários, proporcionando-lhes a oportunidade de participação em cursos e seminários ligados à sua função. Além, como as demais empresas, da preocupação com a segurança do trabalho. 
A empresa utiliza-se muito da informática em seus processos internos, como por exemplo no processo de aquisição e planejamento da produção. Há também um investimento forte na área de Marketing.

Ela utiliza-se muito de parcerias com projetistas, fornecedores de materiais e subempreiteiros.

Isto tudo é feito para que a empresa se mantenha competitiva no mercado, principalmente devido à necessidade de se manter a equipe enxuta, apesar de seu porte. Possui cerca de 20 funcionários e destes, 10 são do escritório. O comando da empresa está nas mãos dos três sócios, e a organização está distribuída nos planos estratégico, tático e operacional. A Figura 21 traz o organograma de funções da empresa C.

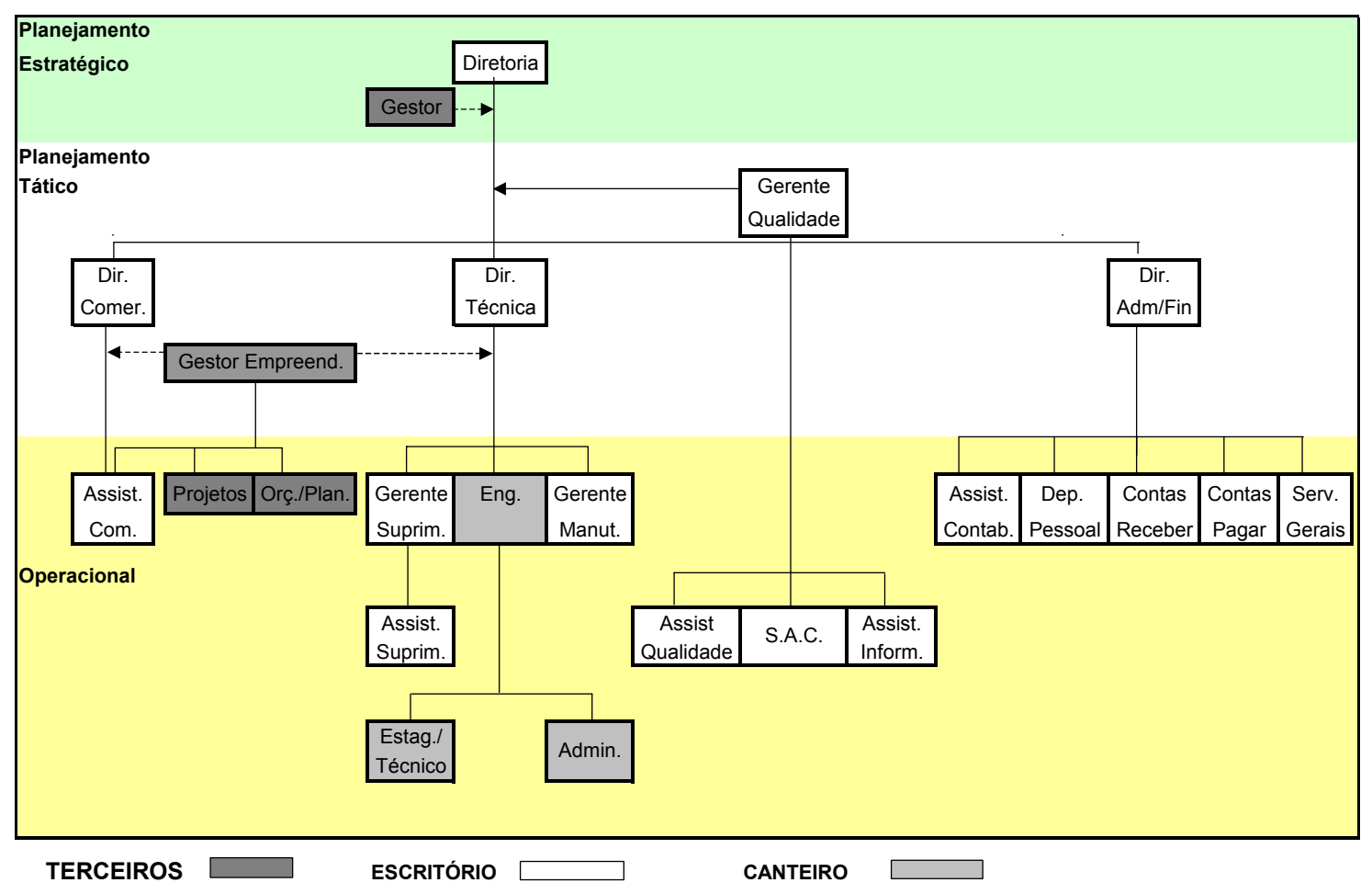

Figura 21 - Organograma de funções da empresa C. (Fonte: empresa C)

Como é mostrado no organograma da Figura 21, a empresa centraliza os assuntos relativos à qualidade nas mãos de seu Gerente da Qualidade, que também é o RD da empresa. Porém isto não quer dizer que o Gerente da Qualidade seja o único 
responsável pelo desenvolvimento, manutenção e atualização do SGQ da empresa; a equipe interna de auditores participa das discussões e decisões relativas ao Sistema.

A empresa conseguiu sua primeira certificação com base na NBR ISO 9002:1994 em outubro de 1999 e para a elaboração de toda sua documentação foi auxiliada pela consultoria da NBS.

De acordo com seu Gerente da Qualidade foram encontrados alguns pontos de resistência durante o processo de implantação do Sistema, como por exemplo, a conscientização da equipe em inspecionar os serviços de obra.

Por se tratar do início da padronização dos processos internos da empresa ele cita que tiveram muitas dificuldades na criação dos procedimentos operacionais e de execução de serviços, pois não havia modelos já existentes para eles se balizarem. Outra colocação é que a implantação do processo de controle de equipamentos de medição, como foi feita inicialmente, foi considerada "sem muita utilidade" para o segmento da empresa.

Em se tratando da melhoria do desempenho da empresa o Gerente da Qualidade, coloca que houve uma melhora nos processos internos e na organização da empresa, porém não há nenhum dado concreto para demonstrar esta melhoria. Isto é, não foram avaliados os processos nem os produtos durante o período em que o sistema da qualidade, baseado na versão de 1994 da NBR ISO 9002, esteve “rodando". A empresa reconhece que não utilizava os indicadores como ferramenta de gestão, uma vez que não estava explicito esta necessidade antes da revisão de 2000.

Em março de 2001 a empresa, agora com o auxílio da consultoria do CTE, iniciou o processo de atualização e também de simplificação de seu SGQ. E em janeiro de 2002 foi auditada e certificada pela Lloyds atendendo todos os requisitos na NBR ISO 9001:2000. Em 2003 a empresa passou a contar com os serviços a UCIEE para o processo de certificação, tendo sido certificada, além da ISO 9001:2000 e Nível A do PBQP-H, também no Nível A do programa QUALIHAB.

Para a adaptação do seu SGQ, a empresa proporcionou aos principais envolvidos cursos de interpretação da nova Norma e curso de atualização de Auditores Internos 
da Qualidade. Estes cursos foram disponibilizados para o Gerente da Qualidade e também para todos os auditores internos da empresa. Todo o desenvolvimento da nova documentação ficou centralizado nas mãos do RD e este discutia em reuniões específicas cada assunto para as tomadas de decisões juntamente com a diretoria, gerentes de departamentos e eng. de obra.

Como a intenção da empresa não foi somente adequar à nova versão, mas também otimizar seu SGQ, foi feita uma análise em todos os processos e verificou-se a oportunidade de simplificar muitos deles; entretanto, para que essa simplificação não diminuísse a eficácia do sistema em prevenir falhas, a empresa acabou elaborando um macro-fluxo (Figura 22) e posteriormente detalhou cada um de seus processos em entradas e saídas identificando os recursos necessários e possíveis interfaces, além das principais deficiências. Um exemplo deste detalhamento de processo está apresentado no Anexo D

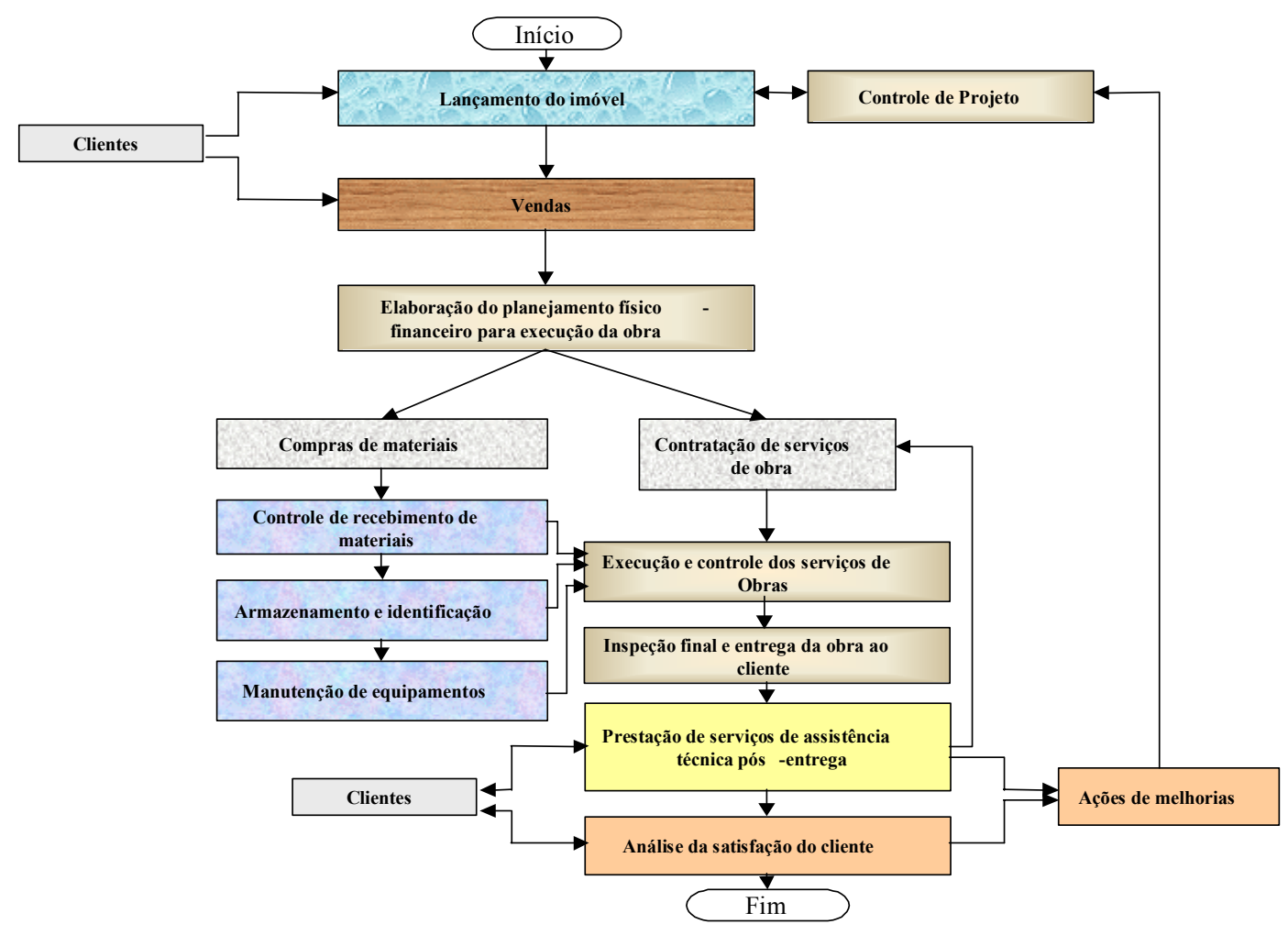

$\begin{array}{ll}\square \text { Lançamento do imóvel } & \square \text { Almoxarifado } \square \text { Suprimentos } \\ \square \text { Vendas } & \square \text { Assistência Técnica } \\ \square \text { Produção } & \square \text { Qualidade }\end{array}$


Figura 22 - Macro-fluxo de processo da empresa C. (Fonte: empresa C)

"O trabalho de verificação e identificação de todas as interfaces destes processos foi de fundamental importância para que os 'gargalos' de cada processo aflorasse. Inicialmente a Diretoria optou por criar metas para monitorar e corrigir as nãoconformidades", declara o Gerente da Qualidade.

Após a identificação dos principais processos e com o conhecimento da norma, foram considerados como requisito de maior importância àqueles que tratam do monitoramento dos processos e produtos pois, através do seu atendimento, a empresa consegue visualizar com dados concretos quais os resultados da implantação do SGQ, quais as principais falhas e quais processos necessitam de maior atenção para se obter o resultado desejado.

Uma das dificuldades encontradas no processo de adequação do sistema da empresa foi demonstrar para a equipe interna quais foram as mudanças conceituais que não resultaram em mudanças de documentação, como conscientização da importância do foco no cliente, comunicação interna, busca pela melhoria contínua. "Não houve dificuldade em atender o requisito, mas sim em passar para a equipe interna a importância destes pontos”, coloca o Gerente da Qualidade da empresa.

Esta dificuldade apresentada acima se traduz nos seguintes requisitos: "Foco no Cliente”, “Objetivo da Qualidade”, “Comunicação Interna”. Outro requisito citado como de difícil implantação, porém não muito relacionado com estes já citados anteriormente, trata dos "Recursos Humanos". A dificuldade se dá principalmente no item que trata da avaliação da eficácia das ações de treinamento.

Como resultado da adequação de seu sistema a empresa deseja saber como estão seus diversos processos, buscando melhorá-los com a "maturação" do SGQ. Em sua reunião de análise crítica realizada em 25/03/2003, a direção concluiu que houve uma melhoria da eficácia do Sistema de Gestão da Qualidade, de seus processos e melhoria geral de seus produtos em relação à percepção dos clientes.

Com relação aos setores da empresa, foi colocado que aqueles que sofreram maiores intervenções foram os de Assistência Técnica, de Planejamento e de Projeto. Ele cita 
que "os setores de projetos e planejamento foram aprimorados, não por obrigatoriedade da norma, mas sim aproveitando a oportunidade, pois estes dois setores já atenderiam a versão 2000”.

$\mathrm{Na}$ linha de produção, ou seja nos canteiros de obra, o engenheiro residente é o principal responsável tanto pelo gerenciamento do empreendimento como também pelo SGQ.

As informações sobre a mudança foram passadas ao pessoal de campo através de treinamentos que eram realizados e ainda são no mínimo uma vez por mês. Na fase de implementação o RD dava um suporte aos engenheiros nas atividades de treinamento.

As principais mudanças observadas pelos engenheiros foram de ordem gerencial com a criação de metas específicas para a obra. "Em se tratando de SGQ, a mudança realmente observada foi a necessidade de se analisar todas as informações obtidas através das inspeções para se obter dados que alimentam os indicadores da qualidade", comenta o engenheiro residente. Os objetivos criados para a obra estão apresentados na Tabela 9.

Tabela 9: Objetivos, indicadores e metas para os processos de produção (Fonte: Empresa C).

\begin{tabular}{|c|c|c|}
\hline Objetivo & Indicador & Meta \\
\hline $\begin{array}{l}\text { Redução do } \\
\text { retrabalho nos } \\
\text { serviços monitorados }\end{array}$ & $I=\frac{n^{o} \text { de inspeções reprovadas por Serviço }}{n^{o} \text { insp. realizadas por Serviço }} \times 100$ & $I \leq 10 \%$ \\
\hline $\begin{array}{l}\text { Reduzir } n^{o} \text { de } \\
\text { acidentes com } \\
\text { afastamento }\end{array}$ & $I=$ Total de acidentes com afastamento por obra & $\begin{array}{c}\text { Máximo } 1 \\
\text { acidente por } \\
\text { semestre }\end{array}$ \\
\hline $\begin{array}{l}\text { Aumentar a eficácia } \\
\text { das inspeções no } \\
\text { processo }\end{array}$ & $I=\frac{\text { aptos sem reprovação na inspeção final }}{n^{\circ} \text { aptos total da obra }} \times 100$ & $I \leq 30 \%$ \\
\hline $\begin{array}{l}\text { Aumento de aptos } \\
\text { recebidos pelos } \\
\text { clientes na } 1^{\mathrm{a}} \text { vistoria }\end{array}$ & $I=\frac{n^{o} \text { de aptos aceitos } n a 1^{a} \text { vistoria }}{n^{o} \text { aptos entregues }} \times 100$ & $I \geq 70 \%$ \\
\hline $\begin{array}{l}\text { Melhorar o } \\
\text { desempenho do } \\
\text { processo de } \\
\text { almoxarifado }\end{array}$ & $\begin{array}{c}I=\text { Total de pontos obtidos no Formulário de } \\
\text { Monitoramento de Almoxarifado }\end{array}$ & $\begin{array}{l}I \geq 50 \\
\text { pontos }\end{array}$ \\
\hline
\end{tabular}


Foram apresentados pela empresa os resultados obtidos pelo monitoramento dos processos através dos indicadores apresentados anteriormente.

Para o objetivo de redução de retrabalho de serviços monitorados, mostra-se na Figura 23 a evolução deste indicador ao longo de três obras que já terminaram e que foram monitoradas desde o seu início.

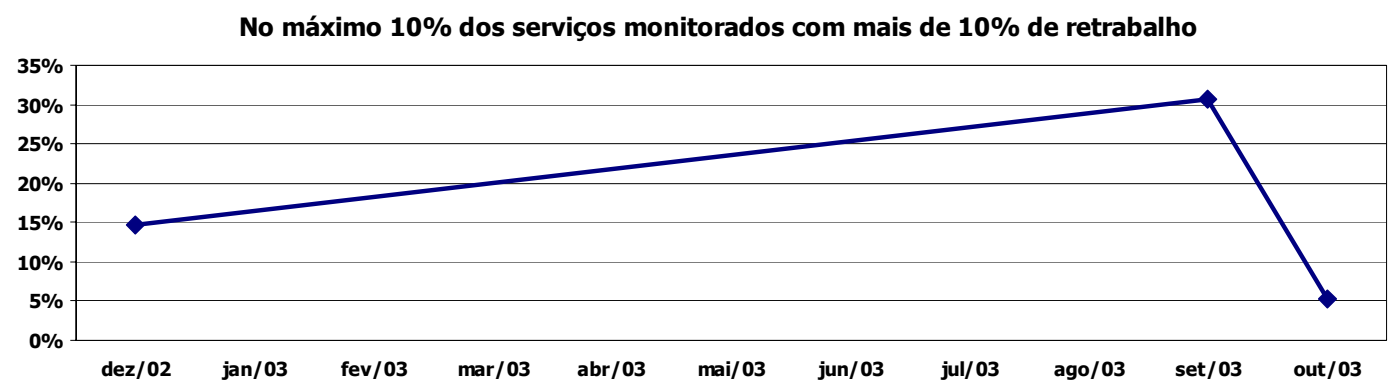

Figura 23 - Evolução do índice de retrabalho (Fonte: Empresa C)

Foi detectado que uma das obras foi a responsável pela elevação do índice em um determinado momento devido a um problema específico nos serviços de pintura, a identificação da causa apontou para o subempreiteiro, que foi desqualificado pela empresa.

Já para o objetivo de redução do número de acidentes com afastamentos, a Figura 24 demonstra uma evolução e principalmente a manutenção de um índice, considerado baixo pela empresa.

Ter no máximo 1 acidente com afastamento por obra

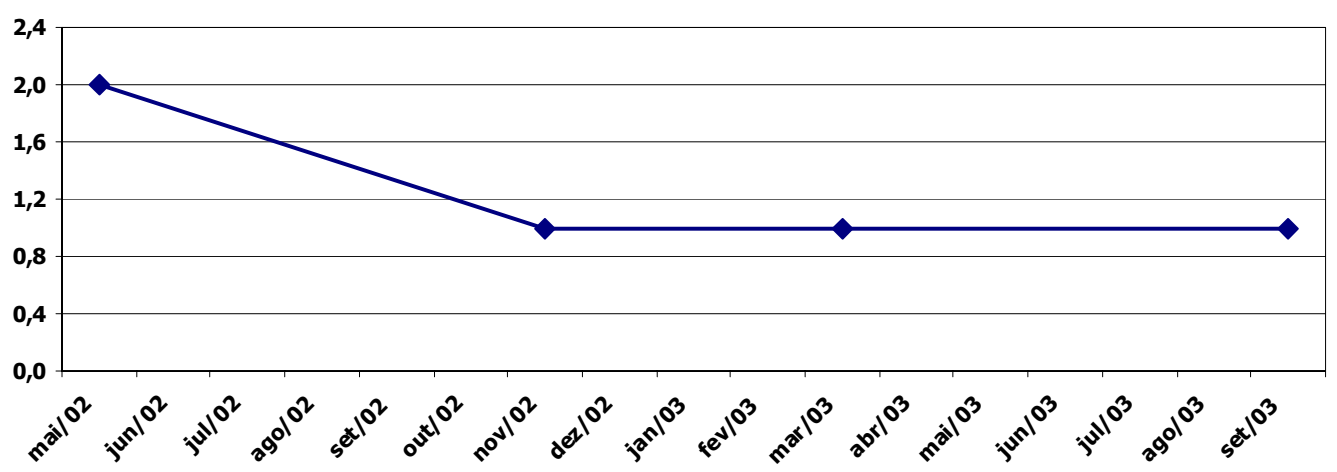

Figura 24 - Evolução do número de acidentes com afastamento (Fonte: Empresa C) 
De acordo com o Gerente da Qualidade, deve-se considerar na análise, que um dia de afastamento é o suficiente para que este número apareça no cálculo do indicador, foi ressaltado que no histórico da empresa não há acidentes considerados graves.

$\mathrm{Na}$ verificação da eficácia dos monitoramentos dos processos de execução de obra foram apresentados os seguintes resultados (Figura 25).

\section{Não ter nenhum item com mais de $30 \%$ de reprovação no Check- List de final obra (F06-2)}

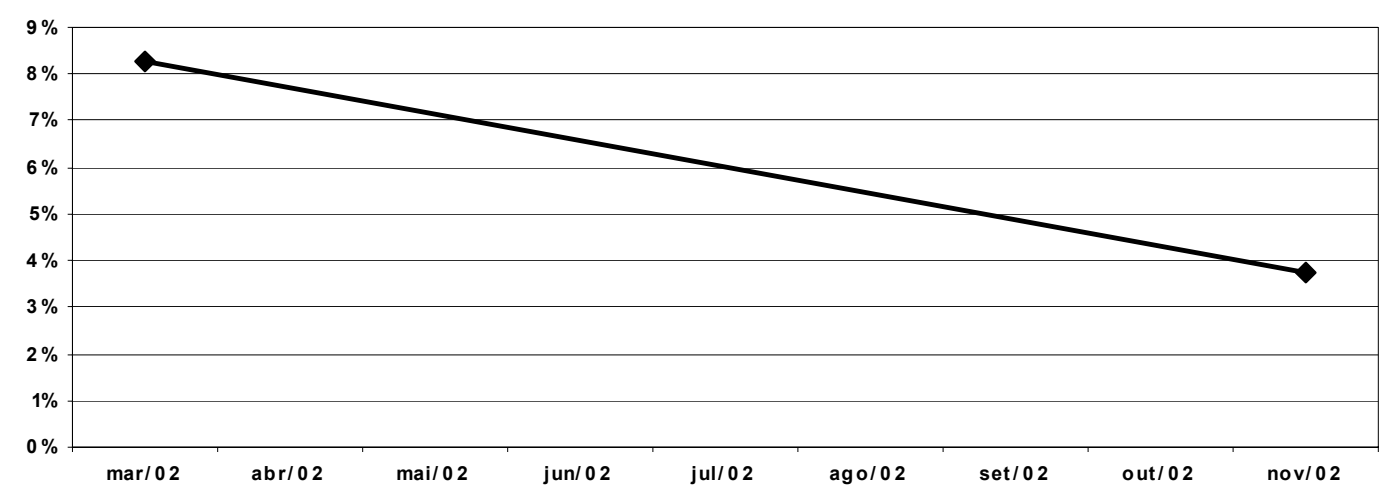

Figura 25 - Monitoramento das inspeções de processos (Fonte: Empresa C).

Por ter sido criado em um momento posterior, esse monitoramento apresenta o resultado obtido apenas em duas obras, porém já é possível ver a evolução neste período. Na primeira compilação dos dados, os resultados obtidos demonstram que em mais de $8 \%$ dos serviços foram detectadas falhas em mais de $30 \%$ do check-list de inspeção final; já na segunda, esse índice caiu pela metade.

Conforme relata o Gerente da Qualidade, esta meta foi criada após uma auditoria externa com a finalidade de monitorar a qualidade das inspeções de serviço, pois a empresa aplica um check-list detalhado após o término da limpeza final antes da entrega ao cliente, é neste momento que é possível avaliar a eficiência das inspeções durante o processo.

Esse check-list é visto com muita importância pela diretoria, pois os vícios que não aparecem neste momento, provavelmente se tornarão um problema de manutenção, custo que muitas vezes é de responsabilidade da empresa, comprometendo o resultado final do empreendimento. 
Um outro indicador criado para monitorar o processo de execução de obra trata do índice de retorno para reinspeção dos clientes no ato da entrega. A Figura 26 mostra a evolução deste indicador.

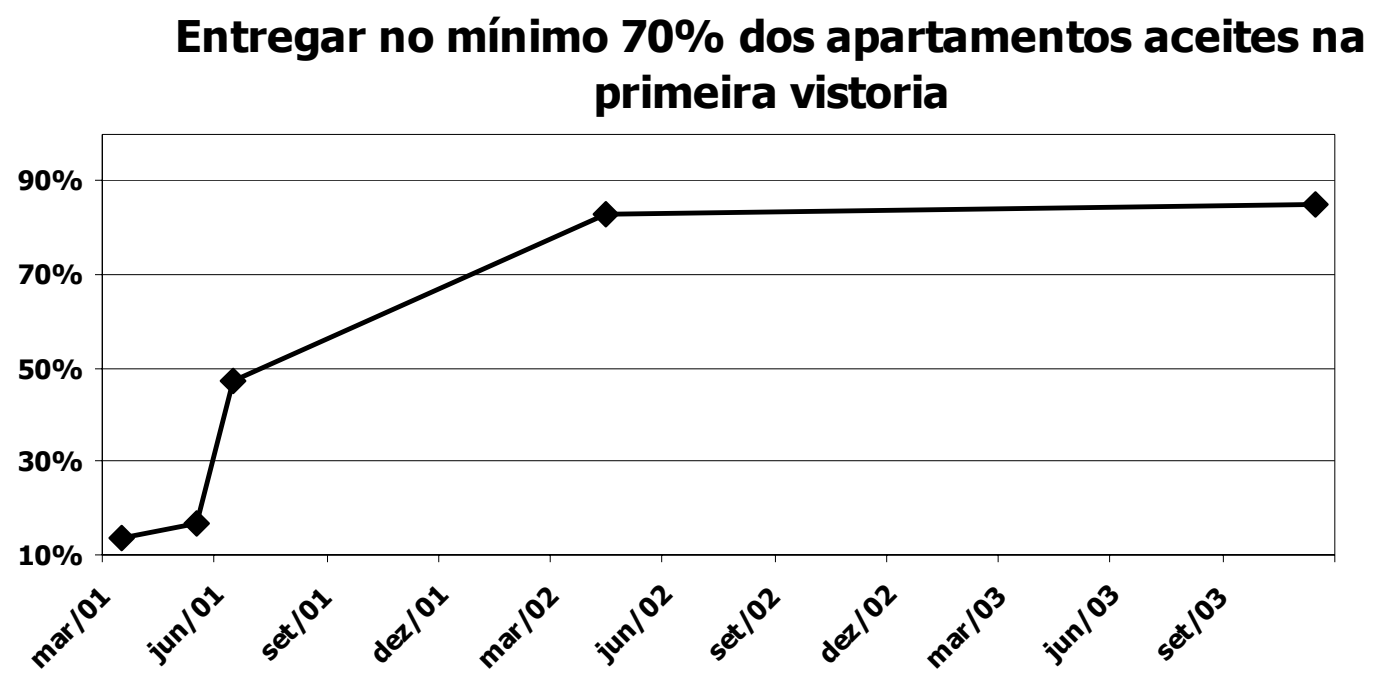

Figura 26 - Índice de entrega de aptos na primeira vistoria. (Fonte: Empresa C)

Esta é uma das metas que apresentaram maior evolução ao longo do tempo. $\mathrm{Na}$ primeira obra monitorada, entregue em abril de 2001, apenas $13,64 \%$ dos clientes receberam o imóvel sem que houvesse nenhum problema, ou seja, mais de $86 \%$ dos clientes retornaram para realizar nova vistoria antes de receberem o imóvel em definitivo. O Empreendimento entregue em novembro de 2002 teve quase $85 \%$ dos clientes recebendo o apartamento na primeira vistoria.

O último indicador criado aplicável para monitoramento dos processos produtivos diz respeito ao desempenho do almoxarifado, onde são levados em consideração pontos como recebimento adequado dos materiais, limpeza e organização de canteiro, organização dos registros da qualidade, manutenção de equipamentos entre outros. Para a verificação deste processo é utilizado um documento, denominado Formulário de Monitoramento do Almoxarifado (Anexo E), onde a cada dois meses o RD da empresa realiza a avaliação.

Conforme declara o Gerente da Qualidade, esta meta, bem como o formulário, foram criados após a necessidade de envolver o responsável administrativo com os indicadores da qualidade e mostrou-se eficiente neste propósito, uma vez que cria 
uma concorrência saudável entre as obras. A Figura 27 mostra a evolução deste indicador.

Obter pontuação maior que $\mathbf{5 0}$ no Formulário de

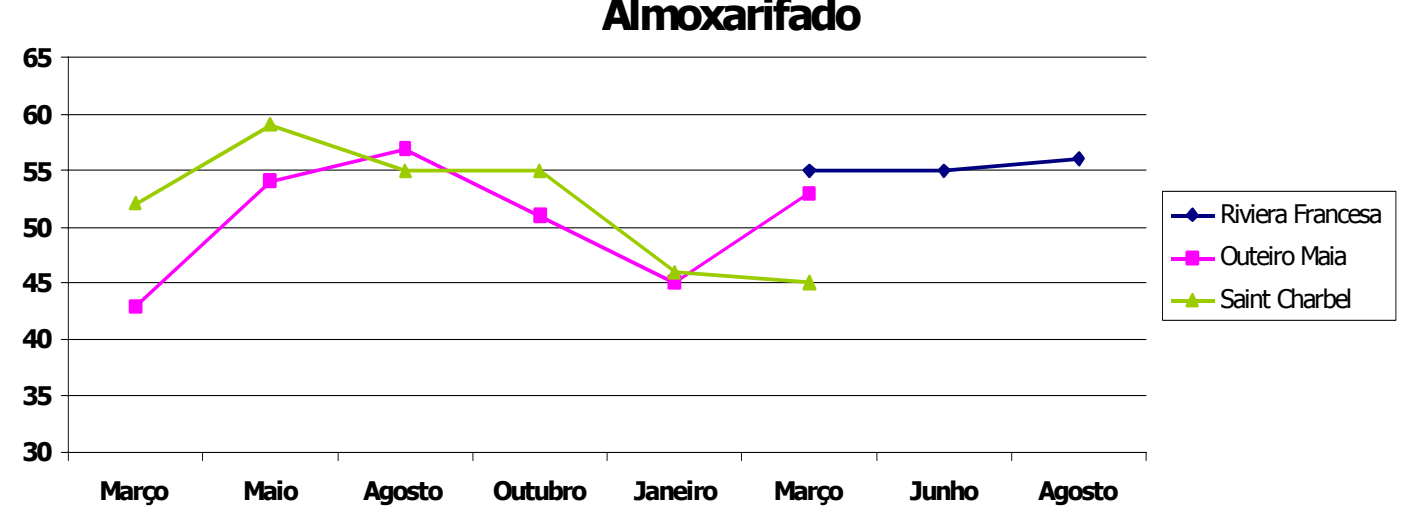

Figura 27 - Evolução do desempenho do almoxarifado (Fonte: Empresa C)

Essa meta teve seu valor aumentado após algumas medições. Quando criada, ela era de 45 pontos e hoje está em 50 pontos, o que significa mais de $78 \%$ da pontuação possível.

Após todas as análises a empresa chega a conclusão que as principais mudanças foram no foco do SGQ, que atualmente está mais preocupado com a eficácia e eficiência dos controles realizados. Com isso quem acaba ganhando é o cliente final, comprador do apartamento, uma vez que a obra tende a acompanhar o aumento do nível de exigência destes clientes. As metas contribuíram muito para isso. 


\subsection{Empresa D}

A última empresa aqui apresentada atua com construções de edificações residenciais de médio padrão e escritórios comerciais. Ela também participa de concorrências para as obras da FDE, porém este tipo de obra não faz parte do escopo da certificação do SGQ implantado pela empresa, nestas obras ainda não são feitos todos os controles necessários de um Sistema de Gestão da Qualidade. Esta exclusão se deve a uma opção estratégica dos diretores da empresa; de acordo com a Coordenadora da Qualidade após a finalização do processo de adequação este tipo de obra também passaria a ser controlado.

A empresa foi fundada no ano 1985 e já entregou um total de 29 obras. Somente uma destas obras foi comercializada a preço fechado, sendo todas as outras contratadas a preço de custo, por administração. Atualmente estão com quatro obras em andamento (a preço de custo), sendo duas em execução e duas em fase de lançamento; contabilizando apenas as duas em andamento, são quase $29.500 \mathrm{~m}^{2}$ de área em construção.

A empresa possui um total de 110 funcionários registrados, sendo que 20 atuam no escritório. A estrutura da empresa é formada pela diretoria composta por oito sócios sendo apenas quatro atuantes e quatro acionistas, dentre os sócios declarados como atuantes cada um ocupa uma das diretorias estratégicas. A Figura 28 traz o organograma da empresa D.

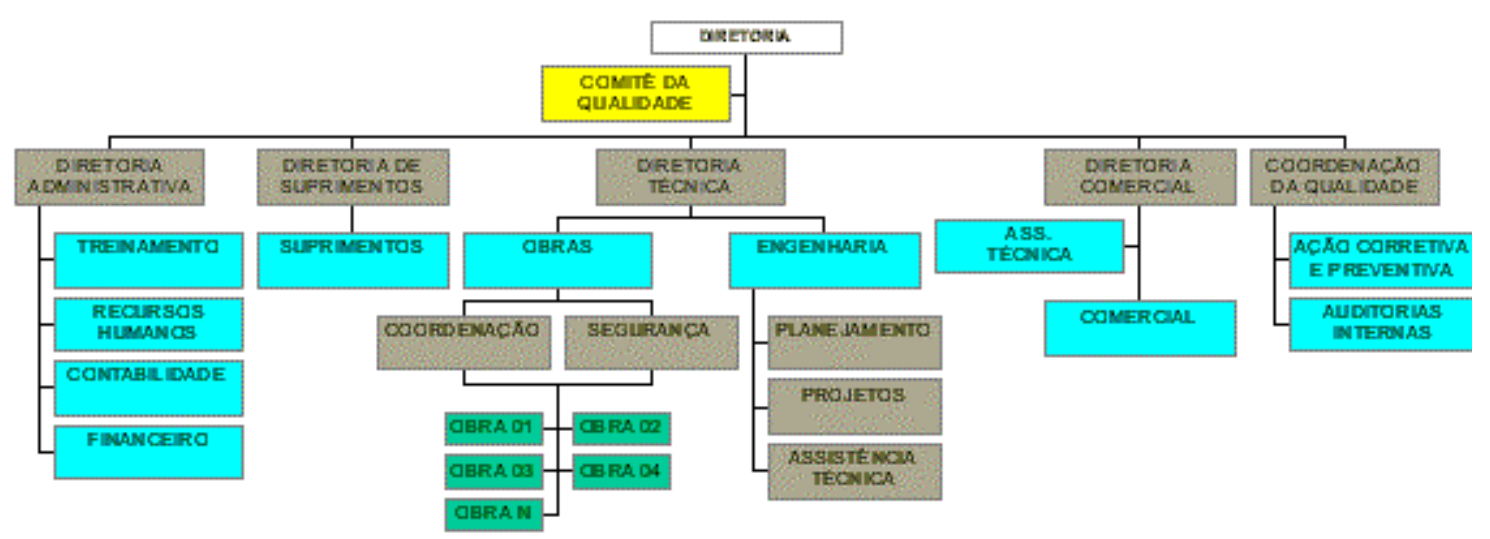

Figura 28 - Organograma de funções da empresa D. (Fonte: empresa D) 
As estratégias utilizadas pela empresa para se manter competitiva estão apresentadas na Tabela 10.

Tabela 10: Estratégias utilizadas pela empresa D para manter a competitividade

\begin{tabular}{|c|c|}
\hline Ações tomadas... & Visando... \\
\hline $\begin{array}{l}\Leftrightarrow \text { Utilização de locação de } \\
\text { equipamentos para a produção }\end{array}$ & $\begin{array}{l}\Leftrightarrow \quad \text { Reduzir custos com manutenção e } \\
\text { ociosidade deste tipo de equipamento. }\end{array}$ \\
\hline $\begin{array}{l}\text { (1) Manter clientes que já compraram da } \\
\text { empresa, fieis à empresa em seus } \\
\text { próximos negócios. }\end{array}$ & 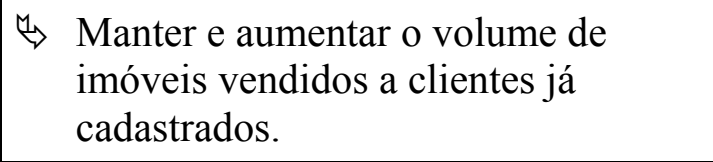 \\
\hline$\stackrel{M}{\rightarrow}$ Manter parcerias com projetistas & 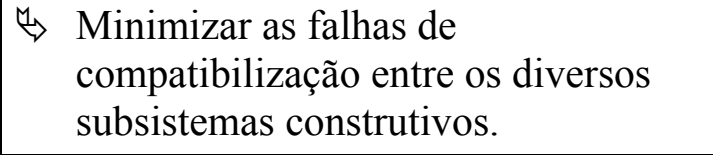 \\
\hline$\stackrel{M}{\rightarrow} \begin{array}{l}\text { Manter parcerias com } \\
\text { subempreiteiros }\end{array}$ & $\begin{array}{l}\stackrel{M}{*} \text { Manter a qualidade e padronização } \\
\text { dos serviços de obra. }\end{array}$ \\
\hline 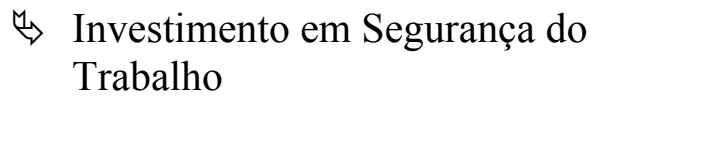 & $\begin{array}{l}\qquad \begin{array}{l}\text { Criar um ambiente saudável e } \\
\text { produtivo dentro dos canteiros da } \\
\text { empresa. }\end{array}\end{array}$ \\
\hline $\begin{array}{l}\Leftrightarrow \text { Aquisição de software para o } \\
\text { processo de aquisição }\end{array}$ & $\begin{array}{l}\Leftrightarrow \text { Agilizar e minimizar as falhas deste } \\
\text { processo. }\end{array}$ \\
\hline 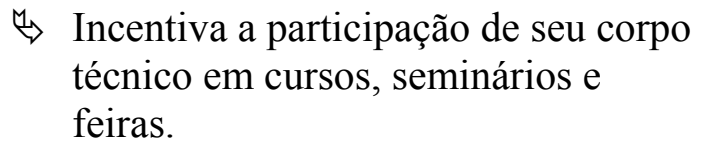 & $\begin{array}{l}\stackrel{M}{H} \text { Manter seu corpo técnico atualizado } \\
\text { com as novas tecnologias do } \\
\text { mercado. }\end{array}$ \\
\hline $\begin{array}{l}\Leftrightarrow \text { Padronizar processos administrativos } \\
\text { além daqueles exigidos pelo SGQ }\end{array}$ & $\begin{array}{l}\Leftrightarrow \text { Criar uma cultura na empresa de } \\
\text { como devem ser realizadas as } \\
\text { atividades internas. }\end{array}$ \\
\hline
\end{tabular}

A Construtora entende que o mercado da construção civil está cada vez mais competitivo. Diante deste cenário, além das estratégias já mencionadas a empresa investiu em novas tecnologias construtivas, decidiu utilizar soluções de racionalização para suas obras, introduzindo novos processos construtivos como, por exemplo, Lajes Planas. "Este tipo de estrutura racional permite melhor performance na execução e também alavanca a empresa na direção da qualidade e produtividade", comenta o Diretor Técnico.

Uma particularidade da organização desta empresa é a forma como é tratada a coordenação da qualidade. Quando se analisa seu organograma verifica-se que a coordenação da qualidade está no mesmo nível hierárquico das diretorias. A empresa quis desta forma explicitar a importância que dá ao seu SGQ. 
Nesta empresa o SGQ não está centralizado nas mãos de uma única pessoa, mas sim de um comitê da qualidade, onde os assuntos são discutidos em reuniões e a partir daí decididas quais serão as responsabilidades de cada integrante deste comitê no desenvolvimento e atualização do Sistema.

Sua primeira certificação com base na NBR ISO 9002:1994 em maio de 2000 contou com o auxílio da consultoria da empresa CTE para repasse técnico, elaboração dos documentos e treinamentos de sua equipe interna. Nesta época, a equipe para o desenvolvimento do SGQ era composta por seis pessoas; atualmente somente três estão ainda na empresa.

No processo de elaboração e posteriormente durante a manutenção do Sistema foi verificada a dificuldade de implementar ações preventivas no dia a dia da empresa e sem isso não promover a melhoria e atualização do sistema. "Com uma equipe reduzida fica difícil manter o sistema atualizado", coloca a coordenadora da qualidade.

Após todo este período com o Sistema implantado há um certo sentimento de melhora do desempenho da empresa que, no entanto, poderia ser maior - supõe a coordenadora. Uma das 'frustrações' do antigo modelo é não conseguir obter dados concretos dos resultados obtidos através dos monitoramentos dos processos.

Atualmente ela verifica que há uma certa necessidade de melhorar a estrutura do SGQ otimizando os documentos.

Buscando solucionar algumas destas 'frustrações' e também para se adequar à nova exigência na NBR ISO 9001 a empresa iniciou em maio de 2002 o processo de atualização, simplificação e adequação de toda sua documentação. Este processo também foi orientado pela mesma empresa de consultoria contratada anteriormente.

Internamente todo o processo ficou centralizado nas mãos de dois integrantes do comitê da qualidade, eles sendo um dos engenheiros de obra e a coordenadora de projeto. "Os trabalhos estão sendo feitos pelos coordenadores da qualidade, somente os planos de metas foram desenvolvidos pelos departamentos (objetivos e indicadores)", declarou a coordenadora da qualidade. Entretanto, a empresa 
disponibilizou cursos de atualização na nova versão da norma e de auditores internos para todos os componentes do Comitê da Qualidade.

A auditoria de certificação realizada pela FCAV, já orientada pela nova versão da ISO 9000, ocorreu em maio de 2003.

Como parte do processo de adaptação do sistema a empresa elaborou um macrofluxo de processos (Figura 29) a fim de identificar as possíveis falhas internas e também criar um sistema de monitoramento mais eficaz.

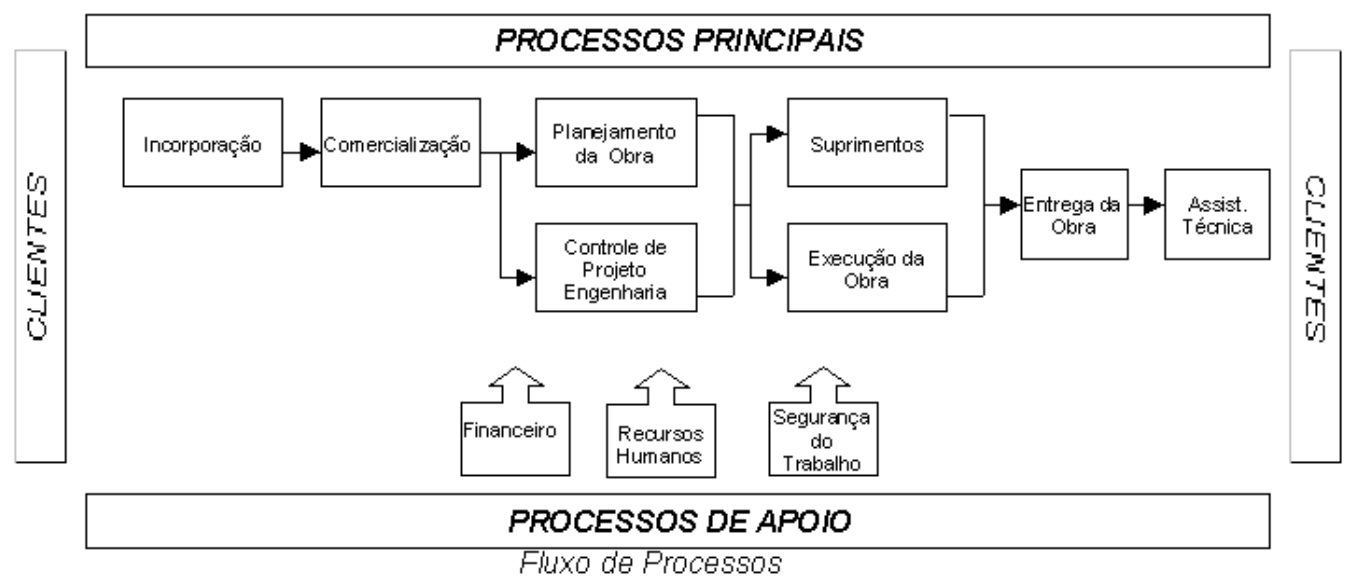

Figura 29 - Macro-fluxo de processo da empresa D (Fonte: empresa D)

Quando questionada sobre os requisitos considerados mais importantes, a coordenadora coloca que todos os requisitos relacionados aos clientes são considerados de extremo valor, mas dá destaque àquele relacionado ao planejamento para a realização do produto, que acaba 'obrigando' a empresa a se organizar e planejar as atividades de obra. Os requisitos relacionados às medições de produto e processo também foram lembrados como importante ferramenta para se avaliar a eficácia de todos os processos da empresa.

Com relação às dificuldades para o atendimento dos requisitos desta nova norma foi levantado que, no momento da análise crítica, há certas dificuldades na análise dos dados provenientes do SGQ, isto é, a empresa ainda não se adaptou à quantidade de informações provenientes dos monitoramentos dos processos e produtos.

Com relação às mudanças nos setores da empresa foi declarado que "em nenhum deles essas mudanças trouxeram grandes impactos, mas, no setor de manutenção e 
atendimento ao cliente, a adequação do SGQ para a versão 2000 trouxe informações antes desconhecidas".

Com a adaptação do seu SGQ, a empresa espera obter um número maior de informações sobre os processos, e com isso ter mais agilidade na compilação dos dados melhorando cada vez mais a qualidade de seus produtos, verificando a percepção dos clientes em todas as etapas de relacionamento.

Nos canteiros de obras, a empresa adota a estratégia da criação de um comitê da qualidade, que normalmente é formado pelo Engenheiro residente, o mestre e o administrativo. A função principal deste comitê é de implementar e manter o SGQ na obra, coordenar as atividades de execução e inspeção, realizar os treinamentos previstos no PQO, coletar e analisar os dados provenientes destas inspeções. Além de alimentar o Comitê central com as informações da obra.

No tocante às mudanças, realizaram-se reuniões com os engenheiros e estes juntamente com o Coordenador da qualidade ficaram responsáveis por informar toda a equipe sobre as alterações sofridas pelo SGQ.

Apesar de não ser efeito direto da nova versão da ISO, a simplificação dos procedimentos foi uma das mudanças mais significativas para a equipe de campo. Foi também lembrada a nova função do comitê da obra com relação aos dados gerados pelas inspeções, que contribuiu para que todo o pessoal da obra se envolvesse com o SGQ. "A partir da implantação deste novo modelo até mesmo o mestre e o almoxarife passaram a criticar alguns pontos do Sistema que poderiam ser melhorados enviando em muitas ocasiões sugestões de melhorias", comenta o Engenheiro.

Ele ainda coloca que as reuniões realizadas, tanto de conscientização como de feedback, e os informativos, com os resultados obtidos através das medições, afixados nos murais das obras foram de extrema importância para difundir este novo conceito de SGQ. 
Com relação aos objetivos relativos aos processos de execução, a empresa coloca que devido a pouca maturidade do Sistema, foram criados apenas dois deles específicos à obra.

Estes objetivos, seus indicadores a as metas definidas para os processos ligados à produção estão apresentadas na Tabela 11.

Tabela 11: Objetivos, indicadores e metas ligadas ao processo produção (Fonte: Empresa D)

\begin{tabular}{||c|c|c|}
\hline Objetivo & Indicador & Meta \\
\hline \hline $\begin{array}{c}\text { Redução do } \\
\text { retrabalho nos } \\
\text { serviços controlados }\end{array}$ & $I=\frac{n^{\circ} \text { de rejeição por Serviço }}{n^{\circ} \text { insp. realizadas por Serviço }} \times 100$ & $I \leq 20 \%$ \\
\hline $\begin{array}{c}\text { Reduzir o número de } \\
\text { falhas no } \\
\text { recebimento de } \\
\text { materiais }\end{array}$ & $I=\frac{n^{0} \text { de entregas com problemas }}{n^{0} \text { total entregas no mês }} \times 100$ & $I \leq 5 \%$ \\
\hline
\end{tabular}

$\mathrm{Na}$ primeira análise dos resultados foram observadas algumas distorções devido a generalização destes indicadores.

Foi relatado que para alguns serviços o índice de falhas é praticamente nulo, nestes casos a meta de $20 \%$ não faz muito sentido, em outros casos o número de falhas supera e muito esta meta. Foram apresentados como exemplos os serviços de concretagem e revestimento em gesso. No primeiro foram obtidos apenas $3 \%$ de falhas, já no segundo o resultado foi de $38 \%$.

Em reuniões realizadas nos canteiros foi relatada, por um dos mestres, a necessidade de se criar metas distintas para serviços que exigissem critérios mais rígidos de liberação. No serviço de revestimento de gesso as inspeções são bem rígidas pois se trata de um dos serviços de acabamento.

Foi percebido pela empresa que a auditoria ficou mais focada na verificação do envolvimento das pessoas, isto é, se elas realmente conheciam o SGQ da empresa e quais eram os objetivos pertinentes ao processo que eles estavam envolvidos. Isto foi verificado tanto na obra como no escritório. 
Notou-se que falta ainda o amadurecimento do SGQ, porém já foi verificado maior envolvimento de toda a equipe de obra e também maior participação no que diz respeito ao aprimoramento do SGQ. A equipe da obra passou a contribuir com sugestões para a criação, melhoria ou substituição de indicadores referentes aos seus processos.

Segundo o Diretor Técnico, a certificação tornou possível organizar processos e a analisar qualitativamente seus resultados, de forma ágil e dinâmica, e em todos os departamentos da empresa.

\subsection{Comparação entre as empresas}

As quatro empresas observadas aproveitaram a "obrigatoriedade" da adaptação de seus SGQ para atender à NBR ISO 9001:2000 como oportunidade de simplificarem e otimizarem toda sua documentação, tornando-a mais prática para a sua utilização no dia-a-dia.

$\mathrm{Na}$ Tabela 12 são apresentados os principais pontos identificados nas empresas tomadas nos estudos de caso.

Tabela 12: Quadro comparativo dos estudos de caso

\begin{tabular}{|c|c|c|c|c|}
\hline & Empresa A & Empresa B & Empresa C & Empresa D \\
\hline Fundação & - 1983 & - 1990 & - 1988 & - 1985 \\
\hline Obras entregues & - 66 & - 12 & - 25 & - 29 \\
\hline N. funcionários & - 400 & - 106 & $\begin{array}{l}\text { - } 20 \text { (m.o. da } \\
\text { produção toda } \\
\text { subempreitada) }\end{array}$ & - 110 \\
\hline $\begin{array}{l}\text { Característica da } \\
\text { organização }\end{array}$ & $\begin{array}{l}\text { - Centralizada } \\
\text { na alta direção }\end{array}$ & $\begin{array}{l}\text { - Equipe } \\
\text { participativa } \\
\text { nas decisões }\end{array}$ & $\begin{array}{l}\text { Dividida em } \\
\text { planos } \\
\text { estratégico, } \\
\text { tático e } \\
\text { operacional }\end{array}$ & $\begin{array}{l}\text { - Dividida em } \\
\text { sócios } \\
\text { "atuantes" e } \\
\text { sócios } \\
\text { acionistas. }\end{array}$ \\
\hline $\begin{array}{c}\text { Área em } \\
\text { construção no } \\
\text { momento da } \\
\text { pesquisa }\end{array}$ & - $80.000 \mathrm{~m}^{2}$ & - $\quad 29.000 \mathrm{~m}^{2}$ & - $\quad 30.000 \mathrm{~m}^{2}$ & - $29.500 \mathrm{~m}^{2}$ \\
\hline Área de atuação & $\begin{array}{l}\text { Habitação } \\
\text { popular; } \\
\text { - Edificação } \\
\text { residencial } \\
\text { médio padrão; }\end{array}$ & $\begin{array}{l}\text { - } \quad \text { Edificação } \\
\text { residencial de } \\
\text { alto padrão; } \\
\text { - } \quad \text { Escritórios } \\
\text { comerciais }\end{array}$ & $\begin{array}{l}\text { Edifícios } \\
\text { residenciais de } \\
\text { alto e médio } \\
\text { padrão; } \\
\text { - Habitação } \\
\end{array}$ & $\begin{array}{l}\text { - Edifícios } \\
\text { residenciais de } \\
\text { médio padrão; } \\
\text { - Escritórios } \\
\text { comerciais; }\end{array}$ \\
\hline
\end{tabular}




\begin{tabular}{|c|c|c|c|c|}
\hline & Empresa A & Empresa B & Empresa C & Empresa D \\
\hline & $\begin{array}{l}\text { - Construção } \\
\text { galpões } \\
\text { industriais. }\end{array}$ & & $\begin{array}{l}\text { popular; } \\
\text { - } \quad \text { Escritórios } \\
\text { comerciais; } \\
\text { - Pequena } \\
\text { participação em } \\
\text { recuperação de } \\
\text { galpões } \\
\text { industriais. } \\
\end{array}$ & $\begin{array}{l}\text { - Habitação } \\
\text { popular }\end{array}$ \\
\hline Recursos & $\begin{array}{l}\text { - Próprios; } \\
\text { - Terceiros; } \\
\text { - Financiamen } \\
\text { to pelo SFH e } \\
\text { CDHU }\end{array}$ & $\begin{array}{l}\text { Próprios; } \\
\text { - } \quad \text { Financiamen } \\
\text { to bancário }\end{array}$ & $\begin{array}{l}\text { - } \quad \text { Próprios; } \\
\text { - Terceiros; } \\
\text { - Financiamento } \\
\text { bancário }\end{array}$ & - Próprios \\
\hline $\begin{array}{l}\text { Primeira } \\
\text { certificação }\end{array}$ & $\begin{array}{l}\text { • } 1998 \\
\text { (Qualihab) }\end{array}$ & $\begin{array}{c}\text { • 1999 (ISO } \\
9002: 1994)\end{array}$ & $\begin{array}{c}\text { 1999 (ISO } \\
9002: 1994)\end{array}$ & $\begin{array}{c}\text { • } 2000 \text { (ISO } \\
9002: 1994)\end{array}$ \\
\hline $\begin{array}{c}\text { Certificação ISO } \\
9001: 2000\end{array}$ & $\begin{array}{l}\text { - Ainda não se } \\
\text { certificou }\end{array}$ & $\begin{array}{l}\text { - Dezembro } \\
2002\end{array}$ & - Janeiro 2002 & - Maio 2003 \\
\hline $\begin{array}{l}\text { Dificuldades no } \\
\text { antigo sistema }\end{array}$ & $\begin{array}{l}\text { - Sistema } \\
\text { burocrático; } \\
\text { - Dificuldade } \\
\text { de } \\
\text { engajamento } \\
\text { da equipe }\end{array}$ & $\begin{array}{l}\text { - Dificuldade } \\
\text { inicial de } \\
\text { conscientizaçã } \\
\text { o; } \\
\text { • Documentaç } \\
\text { ão "pesada"; } \\
\text { - Sem dados } \\
\text { concretos } \\
\text { sobre a } \\
\text { melhoria do } \\
\text { desempenho } \\
\text { da empresa. }\end{array}$ & $\begin{array}{l}\text { - Dificuldade da } \\
\text { conscientização } \\
\text { da equipe de } \\
\text { campo em } \\
\text { inspecionar os } \\
\text { serviços de obra. }\end{array}$ & $\begin{array}{l}\text { - Dificuldades } \\
\text { de em } \\
\text { implementar } \\
\text { ações } \\
\text { preventivas } \\
\text { visando a } \\
\text { melhoria do SG }\end{array}$ \\
\hline $\begin{array}{l}\text { Melhoria obtida } \\
\text { com o SG antigo }\end{array}$ & $\begin{array}{l}\text { - } \quad \text { Sem } \\
\text { possibilidade } \\
\text { de avaliação } \\
\text { pela falta de } \\
\text { dados } \\
\text { confiáveis. }\end{array}$ & $\begin{array}{l}\text { - Aparente } \\
\text { melhora, } \\
\text { observado } \\
\text { através dos } \\
\text { índices médios } \\
\text { de satisfação } \\
\text { dos clientes. } \\
\end{array}$ & $\begin{array}{l}\text { - Melhora nos } \\
\text { processos } \\
\text { internos; } \\
\text { - Maior } \\
\text { organização da } \\
\text { empresa }\end{array}$ & $\begin{array}{l}\text { - Aumento do } \\
\text { desempenho da } \\
\text { empresa, porém } \\
\text { sem dados } \\
\text { concretos. }\end{array}$ \\
\hline $\begin{array}{l}\text { Pontos positivos } \\
\text { do novo sistema }\end{array}$ & $\begin{array}{l}\text { - Obrigatoried } \\
\text { ade da } \\
\text { comprovação } \\
\text { do } \\
\text { engajamento } \\
\text { da alta direção }\end{array}$ & $\begin{array}{l}\text { • Maior } \\
\text { integração dos } \\
\text { diversos } \\
\text { departamentos } \\
\text { da empresa. }\end{array}$ & $\begin{array}{l}\text { - Possibilidade } \\
\text { de visualizar a o } \\
\text { desempenho do } \\
\text { SG através dos } \\
\text { monitoramentos }\end{array}$ & $\begin{array}{l}\text { - Obrigatorieda } \\
\text { de do } \\
\text { planejamento } \\
\text { para a } \\
\text { realização do } \\
\text { produto; } \\
\text { - Medições de } \\
\text { desempenho de } \\
\text { processos e } \\
\text { produtos. }\end{array}$ \\
\hline $\begin{array}{l}\text { Mudanças } \\
\text { percebidas }\end{array}$ & $\begin{array}{l}\text { - Equipe } \\
\text { passou a } \\
\text { participar do } \\
\text { SGQ, opinando } \\
\text { para a sua } \\
\text { melhoria. }\end{array}$ & $\begin{array}{l}\text { Documentaç } \\
\text { ão mais } \\
\text { "enxuta" } \\
\text { focada para o } \\
\text { aumento da } \\
\text { competitividad } \\
\text { e da empresa. } \\
\end{array}$ & $\begin{array}{l}\text { - Observou-se } \\
\text { através da ACD } \\
\text { que os clientes } \\
\text { perceberam as } \\
\text { melhorias } \\
\text { implementadas. }\end{array}$ & $\begin{array}{l}\text { - Maior } \\
\text { participação da } \\
\text { equipe no } \\
\text { assuntos do } \\
\text { SGQ. }\end{array}$ \\
\hline
\end{tabular}


Pode-se notar que a empresa $\mathrm{C}$, que possui seu sistema certificado, há mais tempo nos moldes do modelo 2000 da ISO 9001, consegue através das análises críticas identificar em que pontos ou setores ela está se desenvolvendo mais ou se necessita de maior atenção. Já é possível identificar uma melhoria da eficácia de seu sistema, inclusive verificou-se que houve um aumento da percepção de seus clientes com relação a essas melhorias. 


\section{CONSIDERaÇões Finais}

De acordo com Paula; Melhado (2001), cada vez mais se observa que a qualidade vem se tornando um importante fator de competitividade para as empresas construtoras, quer seja pela possibilidade de se obter reduções de custo, quer pela diferenciação que proporciona às organizações e seus produtos ou até mesmo por uma imposição do mercado (PBQP-H). Atualmente, é preciso produzir o melhor produto com maior produtividade, eficiência e economia possível, de acordo com as necessidades e desejos dos clientes.

Amorim (1998) coloca que um dos pilares do SGQ é a documentação adequada de processos e das atividades da produção, de modo a garantir a rastreabilidade dos produtos. Outro aspecto fundamental é a definição de conformidade, ou seja fixar os requisitos de desempenho e, se for o caso, o dimensionamento aos quais o produto entregue deve atender.

Amorim (1998) complementa ainda que essas duas questões apresentam poucas dificuldades para a indústria seriada, onde os processos e produtos repetem-se centenas ou até milhões de vezes e a demanda pode ser objeto de uma prolongada e minuciosa análise, pois, em geral, há possibilidades para uma amortização satisfatória desses investimentos.

Diferentemente de uma indústria de automóvel, remédios ou qualquer bem de consumo com sede fixa, força de trabalho e equipamentos bem definidos, a construção civil apresenta características muito particulares como, por exemplo, o caráter não homogêneo e não seriado de produção devido à singularidade do produto, feito sob encomenda; a dependência de fatores climáticos no processo construtivo; a complexa rede de interferências dos participantes, incluindo usuários, projetistas, financiadores e construtores, entre outros.

Thomaz (1999) coloca que a produção de obras e serviços, em maior ou menor escala, sempre visou o equilíbrio do triênio preço, prazo e qualidade, embora muitas vezes estes conceitos estivessem subentendidos nos contratos. Aspectos dúbios, subentendidos e omissões, com ou sem intenção de dolo, têm causado inúmeros 
prejuízos a consumidores (diretos ou indiretos) e, mesmo que em menor proporção, até mesmo a fornecedores. Considerando as diferentes faces e os inúmeros intervenientes no processo construtivo, é consenso que projetos individuais de boa qualidade não garantem a boa qualidade global do projeto, assim como especificação correta de materiais e serviços, não garantem a boa qualidade da construção.

As Normas da série ISO 9000 procuram justamente analisar o conceito Qualidade de forma sistêmica, debruçando-se, sobretudo, nas inúmeras interfaces existentes desde a concepção da idéia até a concretização do produto, considerando ainda os inúmeros fatores materiais e gerenciais que nela interferem.

Quanto melhores os níveis de interação entre os diversos processos, melhores serão os resultados potenciais; a rigor, todos deveriam ter a visão integrada de todo processo de produção do empreendimento, podendo dessa forma auxiliar mutuamente e promover com maior facilidade os acertos nas inúmeras interfaces.

\subsection{As Alterações da Norma}

Se questionado a algumas pessoas ligadas à Gestão da Qualidade sobre alguns motivos que justificassem uma revisão das Normas da Série ISO 9000, certamente se ouviria algumas dessas justificativas:

$\checkmark$ SGQ "pesado" para a organização com uma documentação em excesso e muitas vezes engessando as rotinas internas das empresas;

$\checkmark$ Auditorias focadas apenas nos documentos e registros dos Sistemas, não buscando agregar valor para a empresa;

$\checkmark$ Sistemas implementados apenas visando demonstrar o atendimento a algum requisito para a equipe auditora;

$\checkmark$ Os objetivos da qualidade não buscavam a melhoria contínua e não tinham a obrigação de serem mensurados;

$\checkmark$ O SGQ não focava os resultados da organização como um todo, mas apenas alguns pontos da organização, normalmente o processo produtivo. 
Aliado a esses argumentos percebia-se a resistência ao processo de implementação do SGQ por alguns funcionários da organização ou até mesmo da Alta Direção. Muitos Sistemas eram implementados com base em modelos genéricos que sequer eram adaptados e muitas vezes não eram apropriados à realidade da empresa, desconsiderando as suas práticas produtivas e sistemáticas gerenciais.

Pode-se também destacar que muitas vezes os consultores não possuíam a especialidade requerida para implementação do SGQ em um determinado tipo de negócio. Esses profissionais possuíam apenas uma formação genérica em qualidade, não contribuindo com a implantação do Sistema para a melhoria das práticas produtivas e gerenciais das empresas.

Ao se depararem com as questões relativas à qualidade, em especial se estruturadas em programas e manuais de gestão da qualidade ou relativos à qualidade total, com todas as prescrições, as pequenas empresas sentem-se perplexas, o que impõe barreiras ao tema, declaram Mitidieri Filho e Tourinho (2001). O processo construtivo convencional para a construção de edifícios residenciais engloba muitas atividades artesanais, cujo controle da qualidade é difícil e geralmente não produz o efeito desejado, complementam.

A Norma apresentada na versão 2000 apresenta de maneira mais clara seu uso e importância; faz menção especial que ela não pretende dar uniformidade aos Sistemas, logo define também que não é sua intenção que as empresas alterem a estrutura de seus Sistemas para se alinhar com os seus requisitos, mas sim que a documentação das empresas devem definir de maneira apropriada as atividades particulares de cada empresa.

Convém salientar que a nova norma ISO 9001 possui uma abrangência muito mais ampla do que a versão de 1994. Trata-se de uma norma mais clara, incluindo a definição de objetivos e metas consistentes com a Política (o que representa um avanço em direção à ISO 14000) e esses objetivos devem ser mensuráveis. As auditorias de produto, para aqueles com exigência de certificação compulsória, passam a ser escopo das revisões gerenciais, além da inclusão de requisitos 
específicos para pesquisa de satisfação do cliente. A Norma possui também requisitos para alocação de recursos, visando à inovação e melhorias da qualidade.

Juran (1993) já colocava que não havia nada na Série ISO 9000 sobre aperfeiçoamento contínuo, satisfação do cliente ou participação dos funcionários. Estes lamentos foram finalmente ouvidos, pois na revisão de 2000 estes tópicos são tratados com particular cuidado.

Algumas considerações importantes devem ser ressaltadas, como o fim da ISO 9002 e da ISO 9003. A norma ISO 9001 substituiu as duas, passando a ser a norma de “Garantia da Qualidade”. Já a norma ISO 9004 não é mais um guia de uso da ISO 9001 e sim a norma de "Gestão da Qualidade". As relações entre "Garantia da Qualidade". e "Gestão da Qualidade”são melhor entendidas na Tabela 13.

Tabela 13: Relação entre "Garantia da Qualidade" e "Gestão da Qualidade” (Fonte: NBS, 2000)

\begin{tabular}{|c|c|}
\hline Garantia da Qualidade & Gestão da Qualidade \\
\hline $\begin{array}{l}\stackrel{4}{\rightarrow} \text { Promover a confiança do cliente no } \\
\text { fornecimento. }\end{array}$ & $\begin{array}{l}\Leftrightarrow \text { Promover a sustentabilidade dos } \\
\text { clientes. }\end{array}$ \\
\hline$\stackrel{\Delta}{\hookrightarrow}$ Foco na qualidade do produto. & $\Leftrightarrow$ Foco na satisfação do cliente. \\
\hline$\Leftrightarrow$ Parte da Gestão da Qualidade & $\begin{array}{l}\Leftrightarrow \text { Relacionada com a excelência } \\
\text { empresarial. }\end{array}$ \\
\hline
\end{tabular}

Pode-se destacar como um dos benefícios a terminologia e a linguagem mais simples que contribui para facilitar sua compreensão e implementação, permitindo uma adequação ao setor menos complexa.

Dentre as mudanças positivas trazidas pela revisão 2000, pode-se ressaltar:

$\checkmark$ SGQ não focado somente em procedimentos documentados;

Foco na satisfação do cliente;

Exigência do maior envolvimento e comprometimento da Alta Direção;

Abordagem por processo e visão sistêmica de todo;

Definição de objetivos para a qualidade mensuráveis; 
$\checkmark$ Obrigatoriedade da análise dos dados gerados pelo Sistema e buscar melhorias;

$\checkmark$ Auditoria também focada por processos.

Pode-se dizer que os modelos de SGQ mudaram de uma inércia documental para um dinamismo de resultados. A Figura 30 mostra a representação dessa idéia.

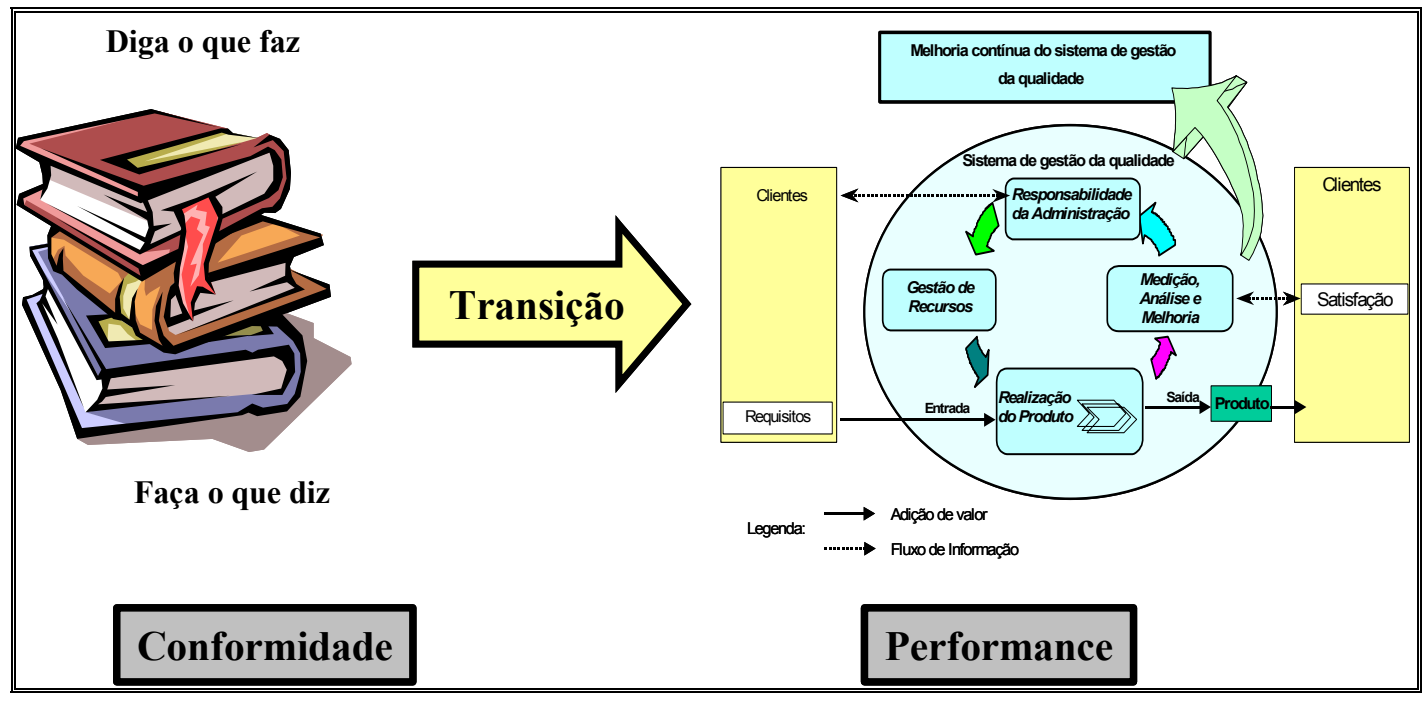

Figura 30 - A Transição para um SGQ Dinâmico (Adaptação de: Hoyle e Thompson, 2001)

A ISO 9001:2000 dá mais ênfase à performance dos resultados e requer a demonstração da melhoria contínua. Isso induz as empresas a manter continuamente esta busca por essa melhoria e também da satisfação dos clientes. A flexibilidade nos requisitos de documentação também é uma das mudanças.

Dentro desse novo conceito, declara o Coordenador de Certificação da UCIEE, a empresa que, uma vez determinando os processos necessários para o SGQ e por conseqüência a gestão do seu próprio negócio, passará a definir os objetivos indicadores e metas para esses processos. A partir daí, utilizando-se da ferramenta do PDCA, a Alta Direção, como toda a organização, poderá monitorar o desempenho de cada processo e tomar ações para que haja uma melhoria contínua do mesmo.

Pode-se concluir que, para cada um dos processos da organização que buscar e alcançar a melhoria contínua, o SGQ como um todo, entenda-se organização, estará melhorando continuamente, conseqüentemente atendendo à satisfação dos clientes, colaboradores acionistas e, por que não dizer, à sociedade. 
Outra alteração importante para o setor é a maior responsabilidade da direção e de seu representante, que agora, além de assegurar o estabelecimento, implementação, manutenção e melhoria da eficácia do sistema de gestão da qualidade e a sua comunicação com a alta direção, deverá promover a conscientização de toda a equipe para o atendimento dos requisitos do cliente.

Uma particularidade observada, não só nas empresas de Construção Civil, é a Alta Direção não conhecer ou não ter idéia de que, para o tipo de produto ou serviço que a empresa oferece, existem requisitos regulamentares e estatutários aplicáveis. Outro ponto é a dificuldade de se entender o conceito de melhoria contínua.

A Alta Direção deve enxergar a empresa por processos e não mais por departamentos com era na versão 94. Essa quebra de paradigma forçará que, ao se planejar o SGQ, seja feita uma análise crítica para que sejam identificados os processos necessários para o SGQ e sua aplicação em toda organização. Esses processos normalmente envolvem mais que um setor ou departamento da organização e podem ter objetivos e indicadores de desempenho comuns.

Apesar de não existir a obrigatoriedade de uma formalização, muitas organizações não conseguem demonstrar como foram feitos o planejamento e desenvolvimento para a realização do produto de cada processo necessário para o SGQ. Algumas empresas não planejam como parte da atividade do requisito 7.2.1 a determinação dos requisitos não declarados pelo cliente, mas necessários para o uso especificado ou intencional, bem como a determinação de requisitos estatutários relacionados a produtos ou serviços fornecidos pela empresa.

A NBR ISO 9001:2000 dá maior ênfase às etapas de projeto e planejamento, trazendo mudanças importantes principalmente para as empresas construtoras que já estavam acostumadas com a NBR ISO 9002:1994, a qual praticamente não possuía exigências relativas a projetos, somente no que se refere aos requisitos contratuais com projetistas. Estas alterações deverão forçar uma maior integração entre as construtoras e seus projetistas e fornecedores para o estabelecimento e atendimento dos requisitos dos clientes. 
O plano da qualidade das obras também ganhou maior destaque, sendo uma parte importante do requisito de planejamento da qualidade. Com isto, deve-se criar nas empresas construtoras uma sistemática de elaboração mais criteriosa do plano antes do início dos serviços nas obras, a fím de ajudar na sua programação e controle posteriores.

\subsection{A Importância do Treinamento}

Provavelmente, a maior deficiência nas atividades de treinamento, que contribui para o alto índice de insucesso, encontra-se no gerenciamento de processos. A certificação de sistemas da qualidade tem colocado a questão do treinamento na pauta do dia-adia. Isso seria uma grande contribuição se não fossem as interpretações equivocadas do conteúdo das normas que servem de referência para esses sistemas de gestão.

É comum encontrar empresas certificadas que implementam programas de treinamento que apenas atendem aos requisitos da norma. Um levantamento de necessidades é feito, treinamentos são executados e registros são elaborados. Tudo feito para mostrar na auditoria. Com tanta preocupação com a auditoria, o resultado ficou em segundo plano. O cliente, então, sequer foi lembrado.

A inclusão das competências necessárias à execução das tarefas traz grandes mudanças para a construção civil, pois comumente a qualificação das equipes de trabalho nas obras fica restrita à experiência registrada em carteira de trabalho, não sendo estabelecidos os requisitos profissionais e pessoais mínimos necessários para o atendimento das necessidades da empresa. Acredita-se que isto trará algumas alterações internas, principalmente na seleção dos profissionais por parte dos departamentos pessoais e administrativos de obras.

O responsável pelo RH tem de conhecer a empresa, seus produtos e principalmente os resultados dos processos e das entregas. Infelizmente, a grande maioria dos profissionais de treinamento desconhece os indicadores de performance da empresa em que trabalham. Questões como quantidade de reclamações, índice de refugo ou retrabalho, devoluções de clientes e outros indicadores não são considerados na elaboração do programa de treinamento. 
Com isso é muito fácil que ele não possua conexão com a realidade e nem compromisso com um resultado operacional posterior. A execução do treinamento deve passar a ser feita como uma atividade fim, e não como atividade de apoio que contribui, mesmo que indiretamente, para o resultados da empresa.

O treinamento deve ser providenciado como parte de um processo de mudança. É inútil enviar 15 pessoas para uma sala de aula se essas pessoas não tiverem uma série de outras providências e atitudes necessárias à mudança. Preparação de planos de ação, concordância e coordenação definida, acompanhamento inicial, preparação de procedimentos, preparação de processos, comunicação, enfim tudo o que seria necessário para se colocar em prática o que foi aprendido.

Infelizmente, só o treinamento não é suficiente para provocar mudanças. É preciso que ele faça parte de um projeto de implantação e que seja inserido no momento oportuno.

O objetivo do treinamento deve referenciar a melhoria no resultado final que se deseja obter e não na eficiência intermediária mais visível. Como exemplo, ficaria mais fácil ao instrutor ministrar seu curso sabendo que seu objetivo é "reduzir o índice de rejeições", ao invés de "capacitar o pessoal a utilizar a metodologia de análise e solução de problemas". A segunda opção leva invariavelmente a pessoa a ser treinada, o analista de treinamento e o próprio instrutor a acreditar que apenas estar capacitado já é suficiente, o que obviamente quase nunca é verdade.

Ao contrário, o vínculo com o objetivo final ajuda o instrutor a direcionar o aprendizado e a potencializar seu resultado através da exemplificação prática similar à situação que as pessoas encontrarão após o treinamento.

À avaliação da eficácia do treinamento. Essa é uma dúvida que está preocupando os responsáveis de RH após a publicação da versão 2000 da norma NBR ISO 9001, onde a avaliação da eficácia passou a ser requisito obrigatório.

Muitas empresas ainda entendem este requisito como o 4.18 (versão 94), onde normalmente era cobrada pela equipe auditora somente treinamento, educação e experiência. Na versão 2000 o requisito 6.2 estabelece que a empresa deve definir, 
além de treinamento, educação e experiência, também a habilidade, que de certa forma pode ser definida com base nas atividades de cada função. Porém existe uma dificuldade em se registrar a habilidade, o que é um requisito normativo.

Outro ponto importante, declara o Coordenador de Certificação da UCIEE, é que as empresas não estão avaliando se, mesmo com o atendimento à qualificação requerida, o funcionário é competente e tem um bom desempenho na função alocada.

\subsection{Agregar Valor com o SGQ}

Apesar do item da auditora interna não ter passado por alterações significativas, notou-se que algumas empresas tendem a realizar essa atividade orientada por requisitos e não por processo como é proposto nesse novo conceito da Norma.

Em cima dessa atividade está a grande expectativa de obtenção de resultados perceptíveis para as empresas, com a implementação de um SGQ. Uma expressão já comum entre os envolvidos com a ISO 9001:200 é de que um SGQ deve "agregar valor" a um processo ou à empresa.

Quality Progress (2004) coloca que para uma auditoria agregue valor a uma organização, ela deve identificar e documentar a conformidade com os requisitos determinados, como os da ISO 9000, e as práticas cotidianas da empresa.

Ao fazer isso, a auditoria analisa profundamente os processos e o sistema de uma empresa. O valor agregado é a identificação de áreas e processos que podem atender aos requisitos da Norma, mas a verificação detalhada do processo pode render bons resultados à organização.

O problema da documentação rígida imposta pela ISO 9000:1994, como já foi amplamente destacado neste trabalho, induzia aos auditores apenas à revisão do Sistema documentado e não dos processos, a auditoria desta forma agregava pouco ou nenhum valor à empresa.

Hoyle e Thompson (2001) colocam que a atividade de auditoria interna tem agora a real oportunidade de se tornar a ferramenta de busca pela melhoria contínua e agregar valor à organização. As auditorias internas terão também que ser planejadas 
com a finalidade de atingir o processo de gestão do negócio, para com isso ter como avaliar os objetivos desse processo.

Para que um SGQ baseado na ISO 9000 ou qualquer outra norma realmente agregue valor, ele deve contribuir para melhorar os fundamentos empresariais. Os oito princípios de gerenciamento nos quais a ISO 90001:2000 é estruturada servem de base para um SGQ eficiente e eficaz. A aplicação correta desses princípios tende a ajudar a reduzir custos e a ineficiência e aumentar os lucros

Crosby (2002) aponta como uma das principais falhas da ISO 9001:2000 a não obrigatoriedade de se medir o preço da não conformidade, pois essa é, segundo ele, a única forma de se medir o custo da não qualidade. Porém é possível e necessário que as organizações se utilizem as cláusulas normativas aqui abordadas, para que meçam este custo e assim é possível, juntamente com os demais requisitos normativos, agregar valor aos seus produtos acabados e à empresa como um todo.

A abordagem factual para a tomada de decisão, que é um desses oito princípios, exige que as decisões sejam feitas com base em dados objetivos. Tais dados apontam para tendências, problemas ou oportunidades que, se tratadas de forma apropriada, terão um efeito positivo na lucratividade de uma empresa.

As análises de dados baseadas em informações factuais também trazem alterações significativas para o setor, pois culturalmente, as informações sobre análise dos processos e produtos na construção civil são subjetivas e não registradas, havendo a necessidade de uma reorientação interna nas empresas neste sentido, ou seja, na escolha e forma de medição dos seus indicadores.

Para algumas empresas, o conceito de se avaliar o desempenho dos processos através da aplicação PDCA não é prática usual, fazendo com que não sejam determinadas ações de melhoria com base no monitoramento dos indicadores de cada processo.

Algumas alterações da versão atual facilitaram significativamente a implementação do SGQ para o setor da construção civil como, por exemplo, a gestão orientada para processos, o que tornou a norma NBR ISO 9001:2000 de mais fácil entendimento por assumir um encadeamento entre os seus requisitos. A utilização de princípios da 
Qualidade Total e a incorporação do ciclo PDCA na estrutura da norma também a tornaram menos áspera na leitura e compreensão.

A ISO 9001:2000 considera todos os aspectos de um sistema operacional, assim ela pode aumentar sua abrangência juntando elementos dos negócios que estão fora da área da qualidade por meio da identificação dos processos e do que está ligado a eles. Ela influencia uma organização a identificar seus processos e suas interações, muitas vezes as interações levam a muitas oportunidades, mas em muitos casos são ignoradas.

Com a identificação preliminar dessas interações e, posteriormente, com a procura de melhorias para elas, diversas empresas podem perceber grandes economias potenciais ou crescimentos reais.

\subsection{As Mudanças no Cenário}

A Indústria da Construção Civil vem sofrendo pressões devido às modificações econômicas ocorridas em todo o mundo. Essas transformações incluem no aspecto produtivo e econômico: abertura do mercado nacional, privatização de empresas estatais, concessões de serviços públicos, lei de licitações, concorrência do setor de construção e redução de preços estabelecidos no mercado.

De acordo com Prado Filho (2003), tudo isso é uma nova realidade conjuntural para as empresas do setor. Nesse novo contexto, a busca pela sobrevivência, em um mercado cada vez mais exigente e competitivo, vem exigindo uma organização com foco na produtividade e preocupada com a gestão da qualidade.

Assim, ela necessita produzir, projetar e construir pensando em reduzir custos e sabendo que é prioritário trabalhar orientado para a gestão da qualidade e produtividade.

Lucena (2003) coloca que o INMETRO realizou, em dezembro de 2002, uma pesquisa com um grupo de empresas, na Federação das Indústrias do Rio de Janeiro, sobre as dificuldades na implantação da NBR ISO 9001:2000. Participaram 400 pessoas, entre empresários, gerentes e técnicos. Os resultados mostram alguns 
aspectos importantes para se entender como está evoluindo esse processo. Perguntados, por exemplo, sobre se conhecem as diferenças entre a NBR ISO 9001:2000 e a série ISO 9000 anterior, 43,2\% dos entrevistados afirmaram desconhecer a questão; $65,1 \%$ colocam a carência de pessoal com capacitação necessária como a principal dificuldade para implementação do sistema de gestão.

Souza (2003), em reportagem ao site CTE, coloca que o movimento pela melhoria da qualidade em nosso setor continua forte e pujante, graças às empresas líderes de vários estados do Brasil que entendem que a gestão da qualidade é um instrumento de melhoria de sua competitividade e de diferenciação no mercado.

Ele ainda diz "é um movimento conduzido por empresas que entendem que o nosso setor além de necessitar de melhores condições de mercado, precisa de um 'choque de gestão' pautado pela adoção de mecanismos de gestão estratégica, gestão dos resultados do negócio, gestão da informação, gestão dos processos e gestão da tecnologia, com foco no cliente e na lucratividade. As margens de lucro se reduziram e vão continuar reduzidas e não há choro que inverta esta situação, há só muito trabalho a ser feito e este trabalho passa obstinadamente por um choque de gestão em nosso setor".

Enfim, a Gestão da Qualidade na Industria da Construção Civil pode também ser um caminho para a solução dos problemas sociais relacionados com o setor produtivo, pois isso pode significar a possibilidade de uma mudança cultural em toda cadeia produtiva.

O construtor deverá ter critérios para analisar cada etapa do ciclo da construção civil, na qual se tem o empreendedor, os projetos, o planejamento, o canteiro de obras, o fornecedor de materiais, a execução das obras, o controle tecnológico, o controle da qualidade, o usuário e por fim a manutenção do empreendimento.

Por se tratar de uma indústria não seriada e caracterizar-se por uma mão-de-obra algumas vezes desqualificada, a Construção Civil é carente e deficitária de um Sistema de Gestão da Qualidade que agregue valor ao seu produto (prédios, casas, 
etc.). Com as alterações feitas nesta revisão da Norma ficou mais fácil aplicá-la nas empresas do setor.

A Construção Civil, que carrega o estigma do desperdício, irá obter inúmeros benefícios se monitorar quantitativamente seus principais processos, dentre eles:

$\checkmark$ Possibilitar à Alta Direção saber quanto produz cada departamento da empresa: suprimentos, vendas, marketing, qualidade, etc;

$\checkmark$ Traçar planos de ação com base em dados factíveis, ou seja, implantar ações corretivas para melhorar os indicadores;

Envolver todas as pessoas da organização, na medida em que se aplique a Norma em todos setores da empresa e não nos níveis gerenciais;

Possibilitar saber quanto custa a não-conformidade.

Para que uma empresa construtora esteja apta a se certificar com base nos requisitos da Norma ISO 9001:2000, são necessários certos mecanismos internos para atender a tais requisitos. A obrigatoriedade da melhoria contínua e do atendimento das necessidades e expectativas dos clientes, com evidências objetivas será a maior dificuldade para empresas do setor da construção.

As empresas terão de estabelecer canais de comunicação com os clientes, a fim de conhecer melhor seu consumidor final e poder satisfazer suas reais necessidades e expectativas. Muitas construtoras já possuem algum tipo de serviço com esta finalidade, porém a sua função se limita na sua maioria em atender solicitações de assistência técnica.

As empresas construtoras deverão implementar contato efetivo com o cliente, considerando requisitos de comunicação tais como:

$\checkmark$ Informação sobre o produto e o serviço;

$\checkmark$ Tratamento de pedidos;

$\checkmark$ Tratamento de reclamações e outros relatos associados a não-conformidades;

$\checkmark$ Processos de rechamada (recall) do produto, onde apropriado; 
$\checkmark$ Feedback do cliente sobre o desempenho do produto ou serviço.

As empresas terão também que desenvolver ferramentas que utilizem indicadores para comprovar a melhoria contínua. Tais indicadores terão que mostrar de forma objetiva que o sistema de gestão da qualidade da empresa garante a melhoria contínua com, por exemplo, diminuição de não conformidades, diminuição de solicitações por reclamações de clientes, aumento do número de entregas de unidades habitacionais em um determinado período, entre outros.

Assim sendo, as construtoras precisam assumir o desafio de mudar os paradigmas que aí estão para modelos que possibilitem outras formas de pensamento sistêmico.

\subsection{Situação das Empresas Estudadas}

Como consenso geral, foi destacada a complexidade de se trabalhar com a versão de 1994 devido principalmente, à sua linguagem de difícil interpretação, além de ter seu foco muito voltado para a indústria seriada.

Todas destacaram a importância do Sistema de Gestão da Qualidade para o seu crescimento. Todas queriam um Sistema que garantisse a qualidade de seu produto final (aptos, casas, etc...) com a melhoria contínua de seus processos produtivos, obtendo ganhos mensuráveis para a empresa.

A alteração do foco desta versão, muito mais voltada para a gestão dos processos, foi muita bem vista nas empresas estudas. A importância dada à mensuração da satisfação dos clientes, da obrigatoriedade dos indicadores da qualidade e da melhoria contínua também foram destacados pelas empresas.

Nas empresas estudadas essas características ficaram evidentes, e também que a implantação de indicadores deve ser um processo contínuo e dinâmico que requer revisão constante até mesmo do próprio indicador, pois algumas vezes a dificuldade de se levantar os dados é maior que o benefício que ele pode trazer e o custo da manutenção de um Sistema de Gestão da Qualidade deve ser levado em conta pela Alta Direção. 
A Melhoria Contínua, muito abordada na ISO 9001:2000, é verificada nas Empresas $\mathrm{B}, \mathrm{C}$ e D, quando se observa que a maioria dos indicadores que foram implantados certamente organizou e trouxe benefício às empresas, pôde-se medir melhorias que não necessariamente foram oriundas dos indicadores, mas através deles foi possível quantificá-las.

A Empresa A, talvez por ter decidido não prosseguir com a certificação ISO 9001:2000, não conseguiu analisar os resultados tão esperados com a implementação de indicadores de desempenho de processos. Com isso eles ainda não possuem a resposta, baseada em fatos, sobre se a empresa realmente obteve ganhos com a implementação do novo Sistema de Gestão.

Nas obras os desafios encontrados para a implementação e atendimento aos requisitos da Norma, se restringiram ao conhecimento de difusão dos indicadores de processos de produção.

Nas quatro empresas pesquisadas foi relatado que esta exigência de envolvimento de toda equipe com o SGQ foi inicialmente encarada como um ponto frágil do Sistema, mas após a difusão dos conceitos, indicadores e metas este receio não se concretizou.

Houve inúmeros relatos onde a participação da equipe de obra contribuiu para a melhoria do SGQ, até mesmo ma solicitação de criação de novos indicadores e metas para o melhor controle de seus processos.

As empresas construtoras concluíram que, para aumentarem sua competitividade no mercado, é preciso buscar novas soluções para os velhos problemas existentes na Construção e, de uma posição de pouca relevância do subsetor, a produção passa a ser o centro das atenções da administração.

Reis e Melhado (1998) colocam que os SGQ'S, que propõem melhorias em todas as etapas do processo de produção, atingiram direta ou indiretamente os canteiros de obras, mudando paradigmas, conceitos e atitudes.

Apesar de ainda existirem alguns obstáculos à implantação dos Sistemas de Gestão da Qualidade nas empresas construtoras, acredita-se que a simples introdução de 
conceitos da qualidade no subsetor serviu para estimular e proporcionar novas perspectivas e idéias para a solução dos problemas existentes há anos.

Obviamente, ainda não se chegou à situação ideal de elevada produtividade e qualidade e baixos índices de desperdício e acidentes no trabalho, mas o caminho que a Construção Civil brasileira trilha atualmente é evolutivo e irreversível.

\subsection{Propostas de continuidade}

Ao longo do desenvolvimento deste trabalho alguns tópicos se revelaram carentes de estudos, de forma que são relacionados aqui com o intuito de estimular o aparecimento de novas pesquisas, complementares a esta.

Por se tratar de um modelo focado em Melhoria Contínua e Gestão do Negócio, fica como sugestão o estudo, em empresas com SGQ certificado com base na NBR ISO 9001:2000, de indicadores de desempenho de processos gerenciais e estratégicos.

Esse tipo de estudo poderia demonstrar se as empresas do Setor da Construção Civil realmente souberam aproveitar a oportunidade que esta versão está proporcionando. 
Anexo A - Modelo da Pesquisa da $1^{\text {a }}$ FASE 


\section{ESCOLA POLITÉCNICA DA UNIVERSIDADE DE SÃO PAULO}

\section{Departamento de Engenharia de Construção Civil}

Pós-Graduação em Engenharia de Construção Civil

\section{Pesquisa ISO 9001:2000}

O questionário a seguir é parte integrante de uma pesquisa de mestrado com o objetivo de identificar os principais impactos ou dificuldades da versão 2000 da Norma NBR ISO 9001 no processo de implantação de um Sistema de Gestão da Qualidade. Esta pesquisa está ambientada no Departamento de Engenharia de Construção Civil da Escola Politécnica da Universidade de São Paulo e coordenada pelo Prof. Dr. Silvio Burrattino Melhado.

Todos os dados enviados serão mantidos em sigilo, não fazendo menção ao nome da empresa em nenhum momento. Ao término da pesquisa ficará a disposição da empresa a conclusão do trabalho.

\section{Dados da Empresa}

Nome da empresa:

Endereço:

Entrevistado:

Função:

Perfil do proprietário:

\begin{tabular}{ll} 
& $\begin{array}{l}\text { Telefone: } \\
\text { Fax: }\end{array}$ \\
Tempo de empresa: & $\begin{array}{l}\text { e-mail: } \\
\end{array}$ \\
\hline $\begin{array}{l}\text { Número de obras } \\
\text { entregues: }\end{array}$ & 3. Número de obras atualmente em \\
& andamento:
\end{tabular}

Telefone:

Fax: andamento:
1. Data da fundação da empresa:
2. Número de obras entregues: $m^{2}$

4. Quantidade aproximada de $\mathrm{m} 2$ em construção, atualmente: Faturamento em 2000:

Faturamento em 2001:

Obs.: Se o valor mencionado for em US\$, favor indicar a taxa de conversão

5. Com relação ao número de empregos gerados por sua empresa, marque uma alternativa em cada coluna:

Total Geral: Total de empregados no escritório:

6. Como é a estrutura organizacional da empresa? (Caso exista um organograma seria possível fornecê-lo? Descreva sucintamente) 
7. Qual(is) o(s) segmento(s) de mercado onde atua? E qual o tipo de contrato mais utilizado para cada segmento? (mais de uma resposta possível)

Tipologia

Habitação popular
Contrato de Venda

Preço de Custo

Preço Fechado

Preço de Custo

Preço Fechado
Escritórios

Shoppings

Construção pesada

Outros:
Preço de Custo

Preço Fechado

Preço de Custo

Preço Fechado

Preço de Custo

Preço Fechado

Preço de Custo

Preço Fechado

Preço de Custo

Preço Fechado

\section{Contrato de Construção}

$\square$ Empreitada global

Empreitada por preço unitário

Administração

Outros:

$\square$ Empreitada global

Empreitada por preço unitário Administração

Outros:

Empreitada global

Empreitada por preço unitário

Administração

Outros:

Empreitada global

Empreitada por preço unitário

Administração

Outros:

$\square$ Empreitada global

Empreitada por preço unitário

Administração

Outros:

Empreitada global

Empreitada por preço unitário

Administração

Outros:

Empreitada global

Empreitada por preço unitário

Administração

Outros:

Empreitada global

Empreitada por preço unitário

Administração

Outros:

8. Quais ações sua empresa tem implementado visando melhorar a sua competitividade?

$\square$ Aquisição de novos equipamentos
$\square$ Locação de novos equipamentos
$\square$ Contratação de consultores
$\square$ Contratação de novos profissionais
$\square$ Estabelecimento de parcerias com clientes
$\square$ Estabelecimento de parcerias com fornecedores
$\square$ Estabelecimento de parcerias com projetistas
$\square$ Estabelecimento de parcerias com outras construtoras
$\square$ Estabelecimento de parcerias com subempreiteiros
$\square$ Implantação de Sistema da Qualidade
$\square$ Investimento em marketing
$\square$ Investimento em informática
$\square$ Investimento em planejamento da produção

$\square$ Investimento em projeto

$\square$ Investimento em RH

Investimento em tecnologia de produção

$\square$ Investimento em inovações (produto)

Investimento em Segurança do Trabalho

$\square$ Melhoria do sistema de aquisição de materiais

Melhoria do sistema de informação para suprimentos

$\square$ Melhoria da assistência técnica fornecida

$\square$ Mudanças organizacionais e gerenciais

$\square$ Padronização dos procedimentos administrativos

Padronização dos procedimentos de execução

$\square$ Participação em feiras

Participação em seminários

Outros: 
9. A empresa desenvolve seus projetos internamente? Quais?
$\square$ Projeto de Arquitetura
$\square$ Projeto de Estrutura
$\square$ Projeto de Instalações
$\square$ Outro:

\section{Sistema de Gestão da Qualidade}

10. Qual foi a data da $1^{\text {a }}$ certificação com base na série ISO 9000 versão 1994 ?

11. A empresa foi preparada por uma empresa de consultoria externa?

$$
\text { a - Qual: }
$$

12. Dentro do sistema já implantado, qual a maior dificuldade para a sua manutenção:

13. Qual a análise com relação ao desempenho da empresa após a implantação do SGQ com base nos requisitos na versão 94 da ISO 9000? A empresa possui dados concretos para subsidiar esta avaliação?

14. A empresa está em processo de transição do seu SGQ para atender a NBR ISO 9001:2000?

a - Em caso afirmativo, quando se deu o início do processo?

b - Em caso negativo, quando a empresa tem a intenção de iniciar o processo?

15. A empresa está sendo ou será preparada por uma empresa de consultoria externa?

$$
\text { a - Qual: }
$$

16. Quando está prevista a auditoria para verificação da adequação do $S G Q$ aos requisitos da nova versão da ISO 9001.

17. A empresa proporcionou um curso para difusão do conhecimento da nova versão da NBR ISO 9001:2000?

a - Dentro da empresa qual a pessoa que possui o maior conhecimento desta norma?

18. A empresa está formando grupos de trabalho para facilitar e envolver a todos neste processo de mudança?

19. Para a empresa, quais os requisitos mais importantes desta nova versão?

20. Dos requisitos relacionados, quais destes teriam maior dificuldades de ser atendidos?
$\square$ Requisito 4 - Sistema de gestão da qualidade
$\square$ 4.2.2 - Manual da Qualidade
$\square$ 4.2.3 - Controle de Documentos
$\square$ 4.2.4 - Controle de Registros

$\begin{array}{ll}\square \text { Requisito 5 - Responsabilidade da } & \square 5.1 \text { - Comprometimento da direção } \\ & \square 5.2 \text { - Foco no cliente } \\ & \square 5.3 \text { - Política da qualidade } \\ & \square 5.4 .1 \text { - Objetivos da qualidade } \\ & \square 5.5 .3 \text { - Comunicação interna } \\ & \square 5.6 \text { - Análise Crítica pela direção }\end{array}$




\begin{tabular}{|c|c|c|}
\hline \multicolumn{2}{|c|}{$\square$ Requisito 6 - Gestão de Recursos } & $\begin{array}{l}\square 6.1 \text { - Provisão de recursos } \\
\square 6.2 \text { - Recursos humanos } \\
\square 6.3 \text { - Infra-estrutura } \\
\square 6.4 \text { - Ambiente de trabalho }\end{array}$ \\
\hline \multicolumn{2}{|c|}{$\square$ Requisito 7 - Realização do produto } & $\begin{array}{l}\square 7.1 \text { - Planejamento da realização do produto } \\
\square 7.2 \text { - Processo relacionados a clientes } \\
\square 7.3 \text { - Projeto e desenvolvimento } \\
\square 7.4 \text { - Aquisição } \\
\square 7.5 \text { - Produção e fornecimento de serviço } \\
\square 7.6 \text { - Controle de dispositivo de medição e monitoramento }\end{array}$ \\
\hline \multicolumn{2}{|c|}{$\begin{array}{l}\square \text { Requisito } 8 \text { - Medição, análise e } \\
\text { monitoramento. }\end{array}$} & $\begin{array}{l}\square \text { 8.2.1 - Satisfação dos clientes } \\
\square \text { 8.2.2 - Auditoria interna } \\
\square \text { 8.2.3 - Medição e monitoramento de processos } \\
\square \text { 8.2.4 - Medição e monitoramento de produto } \\
\square \text { 8.3 - Controle de produto não-conforme } \\
\square \text { 8.4 - Análise de dados } \\
\square \text { 8.5.2 - Ação corretiva } \\
\square \text { 8.5.3 - Ação preventiva }\end{array}$ \\
\hline \multicolumn{3}{|c|}{$\begin{array}{l}\text { 21. Qual setor da empresa sofrerá as maiores mudanças com a implantação de um sistema de gestão da } \\
\text { qualidade baseada na NBR ISO 9001:2000. } \\
\square \text { Técnica } \square \text { Comercial } \square \text { Suprimentos } \\
\square \text { Obras } \square \text { Projetos } \square \text { Recursos Humanos } \square \text { Planejamenãon } \square \text { Atendimento ao cliente } \\
\text { Comentários: }\end{array}$} \\
\hline
\end{tabular}

22. Quais os principais resultados que a empresa espera alcançar com a implantação do sistema de gestão da qualidade baseado na NBR ISO 9001:2000. 
Anexo B - Modelo da Pesquisa da $2^{\text {a }}$ fase 


\section{ESCOLA POLITÉCNICA DA UNIVERSIDADE DE SÃO PAULO}

\section{Departamento de Engenharia de Construção Civil}

Pós-Graduação em Engenharia de Construção Civil

\section{Pesquisa ISO 9001:2000-2 $2^{\mathrm{a}}$ Fase}

Questionário utilizado na segunda fase do estudo de caso, aplicado junto às obras das empresas participantes.

Todos os dados enviados serão mantidos em sigilo, não fazendo menção ao nome da empresa em nenhum momento. Ao término da pesquisa ficará a disposição da empresa a conclusão do trabalho.

\section{Dados da Empresa}

Nome da empresa:

2. Características da Obra tomada como amostra

1. Obra: 2. $\mathrm{m}^{2}$

3. Pavimentos:

4. Unidades:

5. Fase da obra na ocasião da resposta pesquisa:

6. Como é a estrutura organizacional da obra? (Caso exista um organograma seria possível fornecê-lo? Caso contrário descreva sucintamente).

7. Número de funcionário:

Próprios:

Subempreiteiros:

8. Tipos de serviços subempreitados

$\square$ Locação
$\square$ Fundação
$\square$ Estrutura
$\square$ Alvenaria
$\square$ Instalações Elétricas
$\square$ Instalações Hidráulicas

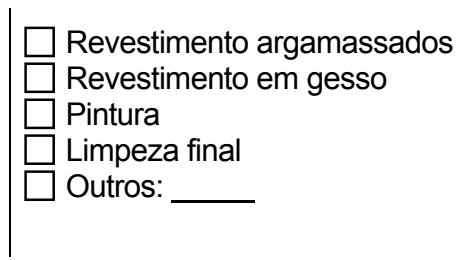

9. Identificação dos recursos disponíveis na obra

$\square$ Betoneira
$\square$ Misturador
$\square$ Equipamento de projeção de argamassa/gesso
$\square$ Fôrmas metálicas
$\square$ Fôrmas de madeira
$\square$ Escoras metálicas
$\square$ Escoras de madeira
$\square$ Reescoramento contínuo
$\square$ Serra circular
$\square$ Serra policorte de bancada
$\square$ Serra policorte manual

$\square$ Grua
$\square$ Guincho de Carga
$\square$ Elevador de passageiro
$\square$ Carrinho porta pallet
$\square$ Gericas
$\square$ Talha
$\square$ Nível a laser
$\square$ Nível alemão
$\square$ Nível de manguiera
$\square$ Taliscas
$\square$ Mestras metálicas

10. Como foi considerado o controle do estoque dos materiais utilizado pela empresa para a aplicação ao produto final?

$\begin{aligned} & \text { Almoxarifado } \\ \square & \text { Limpo } \\ \square & \text { Organizado } \\ \square & \text { Identificado } \\ \square & \text { Comentários: }\end{aligned}$

\begin{tabular}{|c|}
\multicolumn{1}{c|}{ Depósito } \\
$\square$ Limpo \\
$\square$ Organizado \\
$\square$ Identificado \\
$\square$ Comentários:
\end{tabular}

\section{Estoque no campo}

Organizado

Identificado

Comentários: 
11. Como é feito o controle de projetos na obra?

12. Como é a organização destes projetos?

$\square$ Cadernos por especialidade de projeto

$\square$ Mapoteca

$\square$ Soltos

Outro:

\section{Sistema de Gestão da Qualidade - âmbito da obra}

13. Existe um comitê da qualidade da obra? Quem participa?

14. Qual é a função de maior responsabilidade em relação ao sistema da qualidade na obra?
$\square$ Eng. Da Obra
$\square$ Mestre de Obras
Administrativo
$\square$ Estagiário
Almoxarife
$\square$ Técnico
$\square$ Outro:

15. Quais são suas responsabilidades?

16. Como foi passado ao pessoal da obra o processo de adequação do SGQ ao modelo da NBR ISO 9001:2000? Houve a participação de algum membro da obra neste processo?

17. Quais as principais mudanças que afetaram o dia a dia da obra com o novo modelo de SGQ?

18. Foram informados quais são os objetivos para os processos relacionados à obra? Quais são eles?

19. O que foi percebido de diferente durante a auditoria neste novo modelo?

20. O que falta ainda para que o SGQ realmente contribua para melhoria da qualidade dos serviços da obra?

21. Quais os principais resultados que foi identificado, para o ambiente da obra, com a implantação do sistema de gestão da qualidade baseado na NBR ISO 9001:2000. 
Anexo C - Ferramenta para monitoramento de Um dos PROCESSOS DA PRODUÇÃO DA EMPRESA B 


\begin{tabular}{|c|c|c|c|c|c|}
\hline \multicolumn{2}{|c|}{ Empresa B } & \multicolumn{3}{|c|}{$\begin{array}{c}\text { Sistema de Gestão da Qualidade } \\
\text { Check-List de Canteiro }\end{array}$} & Número: \\
\hline \multicolumn{3}{|c|}{ Obra: } & \multicolumn{3}{|c|}{ Mês de referência: } \\
\hline Item & \multicolumn{3}{|c|}{ Verificação } & Atende & $\begin{array}{l}\text { Não } \\
\text { atende }\end{array}$ \\
\hline 01 & \multicolumn{3}{|c|}{ Condições gerais do tapume } & & \\
\hline 02 & \multicolumn{3}{|c|}{ Funcionamento da portaria e guarita } & & \\
\hline 03 & \multicolumn{3}{|c|}{ Limpeza e conservação dos alojamentos/banheiros/refeitórios } & & \\
\hline 04 & \multicolumn{3}{|c|}{ Limpeza do canteiro } & & \\
\hline 05 & \multicolumn{3}{|c|}{ Organização dos estoques externos e internos } & & \\
\hline 06 & \multicolumn{3}{|c|}{ Disponibilidade e conservação de ferramentas } & & \\
\hline 07 & \multicolumn{3}{|c|}{ Disponibilidade e conservação dos equipamentos de produção } & & \\
\hline 08 & \multicolumn{3}{|c|}{ Uso de EPI's } & & \\
\hline 09 & \multicolumn{3}{|c|}{ Condições dos equipamentos de proteção coletiva } & & \\
\hline 10 & \multicolumn{3}{|c|}{ Preenchimento do diário de obra } & & \\
\hline 11 & \multicolumn{3}{|c|}{ Organização dos arquivos e documentos } & & \\
\hline 12 & \multicolumn{3}{|c|}{ Organização dos projetos em uso } & & \\
\hline 13 & \multicolumn{3}{|c|}{$\begin{array}{l}\text { Acompanhamento dos ensaios tecnológicos/planilha de } \\
\text { estruturas }\end{array}$} & & \\
\hline 14 & \multicolumn{3}{|c|}{ Acompanhamento do cronograma físico } & & \\
\hline 15 & \multicolumn{3}{|c|}{ Limpeza de plantão de vendas } & & \\
\hline 16 & \multicolumn{3}{|c|}{ Conservação de cavaletes publicitários } & & \\
\hline \multicolumn{6}{|c|}{$\begin{array}{l}\text { Fórmula para se obter a nota do canteiro }(\mathrm{Nc}): N c=\frac{n^{o} \text { de itens atendidos }}{16} \times 10 \\
\qquad \text { Nota obtida no canteiro: } \mathbf{N c}=\end{array}$} \\
\hline \multicolumn{6}{|c|}{ Observações: } \\
\hline \multicolumn{4}{|c|}{ Realizado por: } & \multicolumn{2}{|c|}{ - $\frac{1}{\text { Data }}$} \\
\hline
\end{tabular}


ANEXo D - ANÁLISE DE PROCESSO DA EMPRESA C 


\section{EMPRESA C}

\section{Identificação dos processos - PRODUÇÃO}

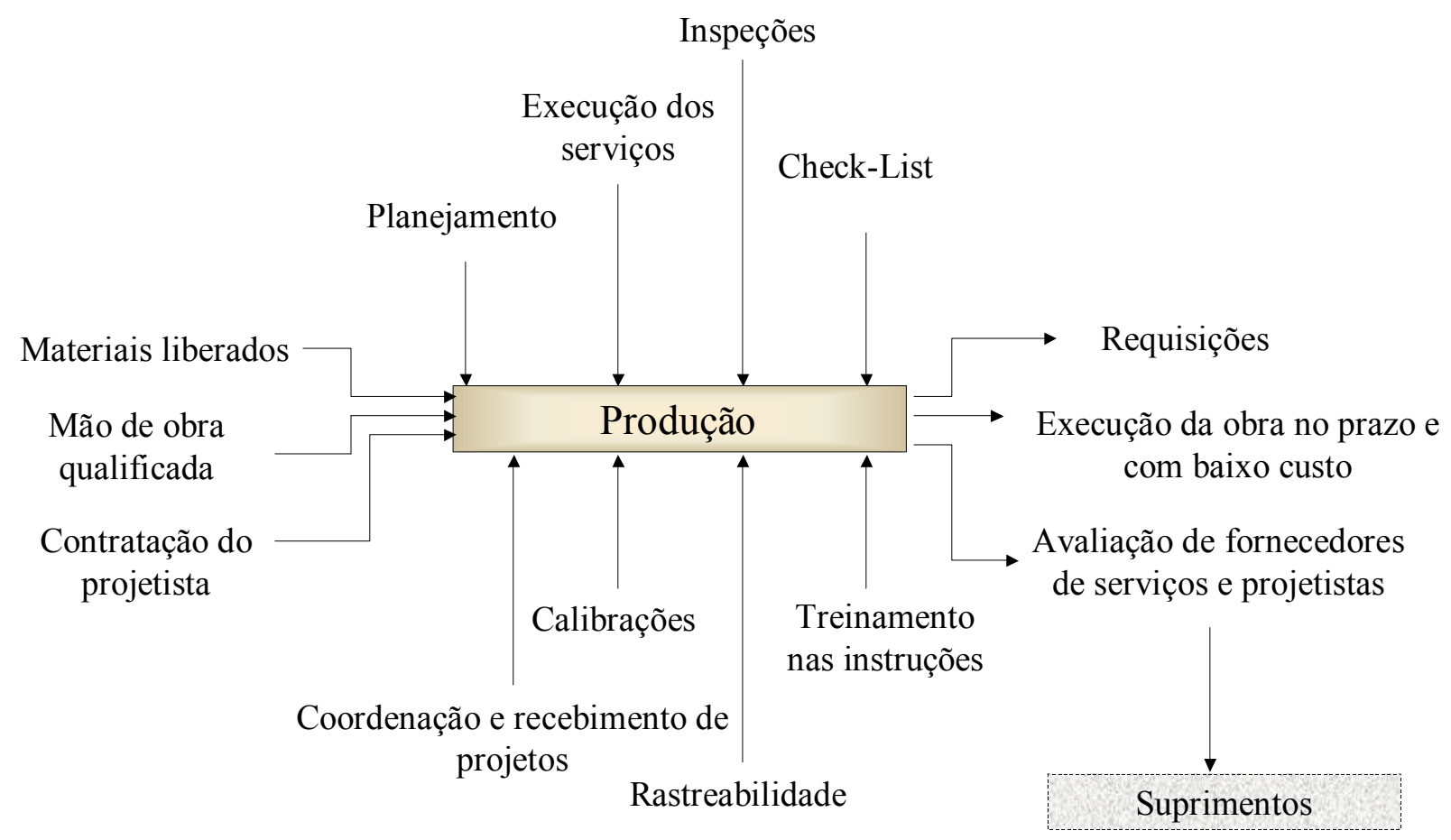




\section{EMPRESA C}

Cód.: Anexo 5

Data: $18 / 11 / 02$

Rev.: 04

Aprov.: Márcio

A atividade de Produção está descrita no P 4.04-1, P 04-2, P 04-3, P 04-4, P 05-1, P 06-2, P 06-3, P 09-2, P 12-1 e I 02-2 e sua interação com os outros processos da empresa está no Manual da Qualidade Seção 4.

Para esse processo a Alta Direção definiu como metas:

\begin{tabular}{|l|l|}
\hline Objetivo: & Reduzir o retrabalho da obra. \\
\hline Meta: & $\begin{array}{l}\text { Não ter acima de } 10 \% \text { de retrabalho nos serviços monitorados, até } \\
\text { agosto de } 2003 .\end{array}$ \\
\hline Indicador: & $I=\frac{n^{\circ} \text { de inspeções reprovadas por Serviço }}{n^{\circ} \text { insp. realizadas por Serviço }} \times 100$ \\
\hline Periodicidade: & A cada 4 meses. \\
\hline
\end{tabular}

\begin{tabular}{|l|l|}
\hline Objetivo: & Reduzir o número de acidentes com afastamento. \\
\hline Meta: & $\begin{array}{l}\text { Ter no máximo um acidente com afastamento a cada semestre por } \\
\text { obra até agosto de } 2003 .\end{array}$ \\
\hline Indicador: & Total de acidentes com afastamento por obra. \\
\hline Periodicidade: & A cada 06 meses. \\
\hline
\end{tabular}

\begin{tabular}{|c|c|}
\hline Objetivo: & Aumentar a eficácia das inspeções no processo. \\
\hline Meta: & $\begin{array}{l}\text { Ter no máximo } 30 \% \text { de itens reprovados por erro de inspeção, no } \\
\text { Check-List de processos F 06-2. Para esta meta será feita } \\
\text { amostragem em } 30 \% \text { das unidades, até agosto de 2003. }\end{array}$ \\
\hline Indicador: & $I=\frac{\text { aptos sem reprovação na inspeção final }}{n^{o} \text { aptos total da obra }} \times 100$ \\
\hline Periodicidade: & Ao término da execução do Check-List. \\
\hline
\end{tabular}




\section{EMPRESA C}

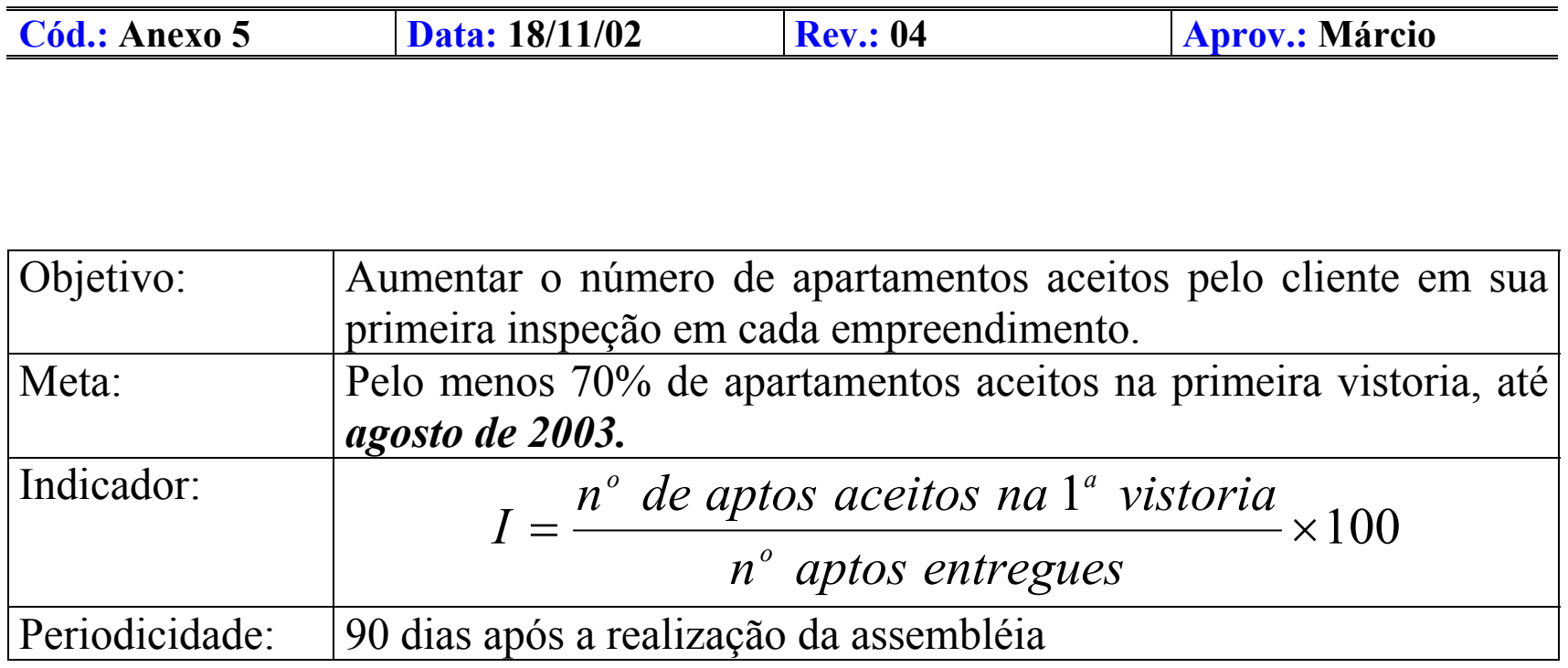

\begin{tabular}{|l|l|}
\hline Objetivo: & Monitorar e melhorar o desempenho do processo do almoxarifado. \\
\hline Meta: & $\begin{array}{l}\text { Obter pontuação maior que } 50 \text { no Formulário de Monitoramento do } \\
\text { Almoxarifado, até agosto de 2003. }\end{array}$ \\
\hline Indicador: & $\begin{array}{l}\text { Total de pontos obtidos no Formulário de Monitoramento de } \\
\text { Almoxarifado }\end{array}$ \\
\hline Periodicidade: & A cada dois meses \\
\hline
\end{tabular}


Anexo E - Ferramenta para monitoramento de UM dos PROCESSOS DA PRODUÇÃO DA EMPRESA C 
Formulário de Monitoramento de Almoxarifado

\begin{tabular}{|c|c|c|c|c|c|}
\hline & & & VALOR & O ITEM & \\
\hline & & & ATENDE & NÃO & PELO \\
\hline 01 & Recebimento de materiais & & 8 & 0 & \\
\hline 02 & Limpeza e organização de & e sua sala & 6 & 0 & \\
\hline 03 & Avaliação de fornecedore & $\mathrm{s}$ de materiais & 7 & 0 & \\
\hline 04 & Organização dos registros & da qualidade & 5 & 0 & \\
\hline 05 & $\begin{array}{l}\text { Frases alusivas à seguran } \\
\text { Qualidade. }\end{array}$ & ça, higiene e Política da & 4 & 0 & \\
\hline 06 & Manutenção dos equipam & entos & 7 & 0 & \\
\hline 07 & Identificação dos pavimer & atos e unidades & 5 & 0 & \\
\hline 08 & Armazenamento dos mate & eriais & 8 & 0 & \\
\hline 09 & Identificação dos materiai & & 4 & 0 & \\
\hline 10 & Documentação dos empre & iteiros regulamentada & 6 & 0 & \\
\hline 11 & Disponibilidade dos mate & riais de higiene e limpeza & 4 & 0 & \\
\hline TOT & L POSSÍVEL 64 pontos & & & & \\
\hline MET & 50 pontos & PONTUAÇÃO OBTIDA: & & & \\
\hline
\end{tabular}




\section{REFERÊNCIAS BIBLIOGRÁFICAS}

ALVES, A.C.N. A Implantação de Sistemas de Gestão da Qualidade na Industria da Construção Civil Segundo os Critérios da ISO 9001:2000: Adaptação em Relação à ISO 9001:1994. Niterói RJ, 2001. Dissertação (Mestrado). Universidade Federal Fluminense. 137p.

AMORIM, S.R.L. Qualidade na Construção: Muito Além da ISO 9000. In CONGRESSO LATINO-AMERICANO DE TECNOLOGIA E GESTÃO NA PRODUÇÃO DE EDIFÍCIOS - SOLUÇÕES PARA O TERCEIRO MILÊNIO. São Paulo, 1998. Anais. São Paulo: EPUSP, 1998. p. 403-408.

ANDRADE, R.; XAVIER, S. ISO 9000: Dicas para Implementação. Rio de Janeiro. QAT: INOVAR, 1996. 256p

ASSOCIAÇÃO BRASILEIRA DE NORMAS TÉCNICAS. NBR ISO 8402 Gestão da Qualidade e Garantia da Qualidade - Terminologia. Rio de Janeiro, 1994.

. Coletânea de Normas Garantia da Qualidade. Rio de Janeiro: ABNT, 1990. 152p

NBR ISO 14001 - Sistema de Gestão da Qualidade - Diretrizes para Melhoria do Desempenho. Rio de Janeiro, 1996.

NBR ISO 19011 - Diretrizes para auditoria de sistema de gestão da qualidade e/ou ambiental. Rio de Janeiro, 2002.

NBR ISO 9000 - Sistema de Gestão da Qualidade - Fundamentos e Vocabulários. Rio de Janeiro, 2000.

Rio de Janeiro, 2000. 
NBR ISO 9004 - Sistema de Gestão da Qualidade - Diretrizes para Melhoria do Desempenho. Rio de Janeiro, 2000.

Coletânea. Rio de Janeiro, 1994.

NBR ISO Família 9000 - Gestão da Qualidade - Normas.

BAÍA, J.L. Sistema de Gestão da Qualidade em Empresas de Projeto: Aplicação à Empresas de Arquitetura. São Paulo, 1998. Dissertação (Mestrado). Escola Politécnica, Universidade de São Paulo. 244p.

BATTISTUZZO, F. ISO 9000: uma reflexão atual Revista Banas Qualidade. N ${ }^{\circ}$ 100 Ano X. Setembro de 2000. p 120 - 121

BRANCHINI, O.J. A ISO 9000:2000 sem mistérios ou segredos. Revista Banas Qualidade. No 117 Ano XI. Fevereiro de 2002. p 18 - 21

CTE - CENTRO DE TECNOLOGIA DE EDIFICAÇÕES. Sistema de gestão da qualidade para empresas construtoras. São Paulo, SEBRAE / SindusCon - SP, 1995. 247p.

CROSBY, P.B. Crosby Fala da Utilidade da ISO 9000:2000. Philip Crosby Associates II Ltda., disponível em $<$ http://www.philipcrosby.com.br $>$ acessado em 21 dezembro de 2002.

. Qualidade é investimento. 3 ${ }^{\mathrm{a}} \mathrm{ed}$. Rio de Janeiro,J.O. Editoria, 1988. $327 p$.

. The Usefulness of ISO 9000:2000. Philip Crosby Associates II Ltda.,

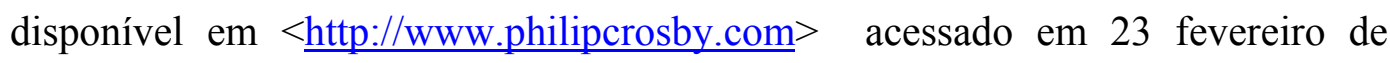
2003.

CORBETT, C.J.; et al. Special Report - Does ISO 9000 Certification Pay? ISO Management System. Geneva: ISO Central Secretariat, July-August 2002 p p 31-

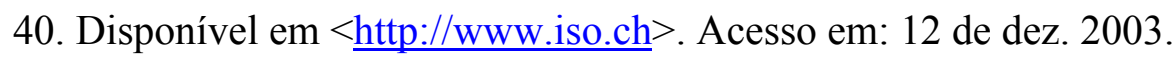


CYSNE, A.M. Descomplicando a ISO 9000:2000 uma visão passo a passo. Revista Banas Qualidade. No 113 Ano XI. Outubro de 2001. p 82 - 83

DE CICCO, F. Comparações Versão 2000x1994. Revista Banas Qualidade. No 93 Ano IX. Fevereiro de 2000. p 18

DEGANI, C.M. Sistemas de Gestão Ambiental em Empresas Construtoras de Edifícios. São Paulo, 2003. Dissertação (Mestrado). Escola Politécnica, Universidade de São Paulo. 223p.

FERREIRA, A.B.H. Novo Dicionário da Língua Portuguesa. Rio de Janeiro, Ed. Nova Fronteira S.A., $19862^{\text {a }}$ Ed. 1838p.

FONTENELlE, E.C. Estudos de Caso Sobre a Gestão do Projeto em Empresas de Incorporação e Construção. São Paulo, 2002. Dissertação (Mestrado). Escola Politécnica, Universidade de São Paulo. 369p.

HOYLE, D.; THOMPSON, J. ISO 9000:2000 - Business as Usual or a Real Challenge? ISO 9000 + ISO 14000 NEWS. Geneva: ISO Central Secretariat, Abril 2001. p 11 - 16. Disponível em $<$ http://www.iso.ch>. Acesso em: 10 de nov. 2003.

INSTITUTO NACIONAL DE METROLOGIA, NORMALIZAÇÃO E QUALIDADE INDUSTRIAL. NIT DICOR 037 - Diretriz do IAF para aplicação do ISO/IEC Guia 62:1996. Rio de Janeiro, nov. 2003.

ISO MANAGEMENT SYSTEM: Special Report - Feedback on ISO 9001:2000 Worldwide Round-up of Early Market Reactions. ISO Management System. Geneva: ISO Central Secretariat, January-February 2002. p 19 - 29. Disponível em $<$ http://www.iso.ch $>$. Acesso em: 15 de jan. 2004.

JATOBÁ, P.C. A auditoria na ISO 9000:2000. Revista Banas Qualidade. No 117 Ano XI. Fevereiro de 2002. p $22-23$ 
JURAN, J.M. A Última Palavra: Lições de uma Vida no Gerenciamento para a Qualidade. Revista Controle da Qualidade. N ${ }^{0} 19$ Ano II. Editora Banas. São Paulo, 1993. p $7-9$.

. Juran na liderança pela qualidade - Um guia para executivos.

São Paulo, Pioneira Novos Rumos, 1990. 386p.

LORDÊLO, P.M. Avaliação das Modificações Introduzidas pela Versão 2000 da Série de Normas NBR ISO 9000: O Caso das Empresas Construtoras de Edifícios. São Paulo, 2002. Monografia. Escola Politécnica, Universidade de São Paulo. 91p.

LUCENA, L.C. ISO 9001:2000 está chegando a hora! Revista Banas Qualidade. No 131 Ano XII. Abril de 2003. p $26-31$

MACIEL, L.L.; MELHADO, S.B. Qualidade na construção civil: fundamentos. São Paulo, 1995. Texto Técnico. Escola Politécnica da USP. Departamento de Engenharia de Construção Civil, TT/PCC/15. 23 p.

MARANHÃO, M. ISO série 9000 - Manual de Implementação. $3^{\mathrm{a}}$ ed. Rio de Janeiro, Qualitymark, 1996.

MELHADO, S.B. Qualidade do projeto na construção de edifícios: aplicação ao caso das empresas de incorporação e construção. São Paulo, 1994. Tese (Doutorado). Escola Politécnica, Universidade de São Paulo. 294p.

MENDONÇA, G. A Vida Depois da ISO. Revista Qualidade na Construção $\mathrm{n}^{\circ} 25$ Ano III 2000. p $32-35$.

MITIDIERI FILHO, C.V.; TOURINHO, M.C.L. Qualidade nas Pequenas Incorporadoras e Construtoras. Revista de Tecnologia e Negócios da Construção - TÉCHNE.. No 57 Ano X. Dezembro de 2001. p 64 - 67

MOTT, J.D. ISO 9000 - Além da certificação. Philip Crosby Associates II Ltda., disponível em <http://www.philipcrosby.com.br>. Acesso em: 19 de mar. 2003. 
NBS - CONSULTING GROUP. ISO 9000 Revisão 2000: Interpretando as Mudanças. $1^{a}$ Ed. São Paulo, 2000. 108p

OLIVEIRA, O.J. Gestão da Qualidade na Industria da Construção Civil. São Paulo, 2001. Dissertação (Mestrado). Pontifícia Universidade Católica de São Paulo. 192p.

PAULA, A.T; MELHADO, S.B. Impacto Potencial da Versão 2000 das Normas ISO 9000 na Gestão e Certificação da Qualidade In II SIMPÓSIO BRASILEIRO DE GESTÃO DA QUALIDADE E ORGANIZAÇÃO DO TRABALHO NO AMBIENTE CONSTRUÍDO. Fortaleza, 2001. Anais. Fortaleza: UFC-UNIFOR, 2001. p. 137-146.

PICCHI, F.A. Sistemas de qualidade: uso em empresas de construção de edifícios. São Paulo, 1993. Tese (Doutorado). Escola Politécnica, Universidade de São Paulo. 462p.

PRADO FILHO, H.R. Dá para Construir com Qualidade no Brasil Revista Banas Qualidade. N ${ }^{\circ} 136$ Ano XIII. Setembro de 2003. p $32-43$.

PRIENTO, V.C. Abordagem sistêmica para a gestão e melhoria contínua. Revista Banas Qualidade. No 124 Ano XII. Setembro de 2002. p 24 - 29

QUALITY PROGRESS. Tentando alcançar o valor agregado com a ISO 9000. Traduzido por Cinthia Garcia Alencar. Revista Banas Qualidade. No 141 Ano XIII. Fevereiro de 2004. p $10-12$.

REIS, P.F. Análise dos efeitos da implantação de sistemas de gestão da qualidade nos processos de produção de pequenas e médias empresas de construção de edifícios. São Paulo, 1998. Dissertação (Mestrado). Escola Politécnica, Universidade de São Paulo. 254p. 
REIS, P.F; MELHADO, S.B. Análise do Impacto da Implantação de Sistemas de Gestão da Qualidade nos Processos de Produção de Pequenas e Médias Empresas de Construção de Edifícios. In CONGRESSO LATINO-AMERICANO DE TECNOLOGIA E GESTÃO NA PRODUÇÃO DE EDIFÍCIOS - SOLUÇÕES PARA O TERCEIRO MILÊNIO. São Paulo, 1998. Anais. São Paulo: EPUSP, 1998. p. 459-467.

ROCHA, S. O século da qualidade. Obra, Planejamento e Construção, n. 101, p.10-16, jun. 1998.

SEDU - SECRETARIA ESPECIAL DE DESAENVOLVIMENTO URBANO DA PRESIDÊNCIA DA REPÚBLICA. Itens e Requisitos do Sistema de Qualificação de Empresas de Serviços e Obras - Construtoras SIQ - Construtoras do PBQP-H. Anexo III da Portaria no 67, de 20 de Dezembro de 2002. Brasília, 2002. $18 p$

SME WORKBOOK WORKING GROUP. London, 2003. Quality Systems in the Small or Medium Sized Enterprise [SME] - A Guide to the Adoption of the ISO 9001:2000 Standard. Institute of Quality Assurance, [IQA], Federation of Small Businesses, [FSB], and the Association of British Certification Bodies, [ABCB]. Disponível em $<$ http://www.abcb.demon.co.uk/ $>$. Acesso em: 31 de jan. 2004.

SOUZA, R. A Qualidade está consolidada, vamos agora para um choque de

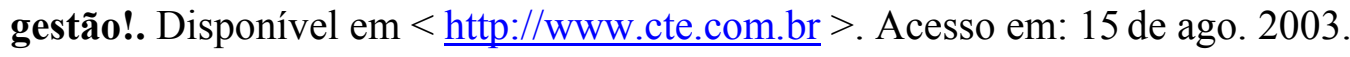

- Metodologia para desenvolvimento e implantação de sistemas de gestão da qualidade em empresas construtoras de pequeno e médio porte. São Paulo, 1997. Tese (Doutorado). Escola Politécnica, Universidade de São Paulo. $335 \mathrm{p}$.

TEIXEIRA, C.A.A. A Evolução da Qualidade. Revista Banas Qualidade. No 100 Ano X. Setembro de 2000. p 74 - 75 
THOMAZ, E. Requisitos Técnicos e Operacionais Visando a Qualidade na Construção de Edifícios. São Paulo, 1999. Tese (Doutorado). Escola Politécnica, Universidade de São Paulo. 474p.

UCIEE - UNIÃO CERTIFICADORA. Diário de Auditoria - Construtoras NBR ISO 9001/00. Documento interno. São Paulo, 2003. 26p. Não publicado 